\title{
International Journal of Research
}

\section{in E-learning}

vol. 4 [2], 2018
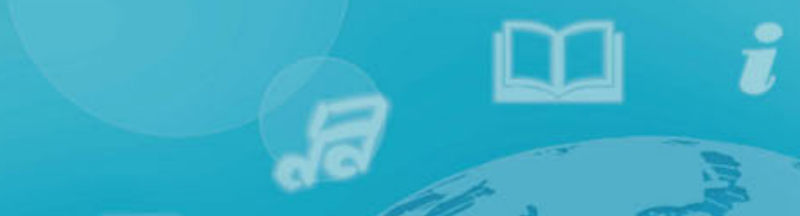

ㅁ

n
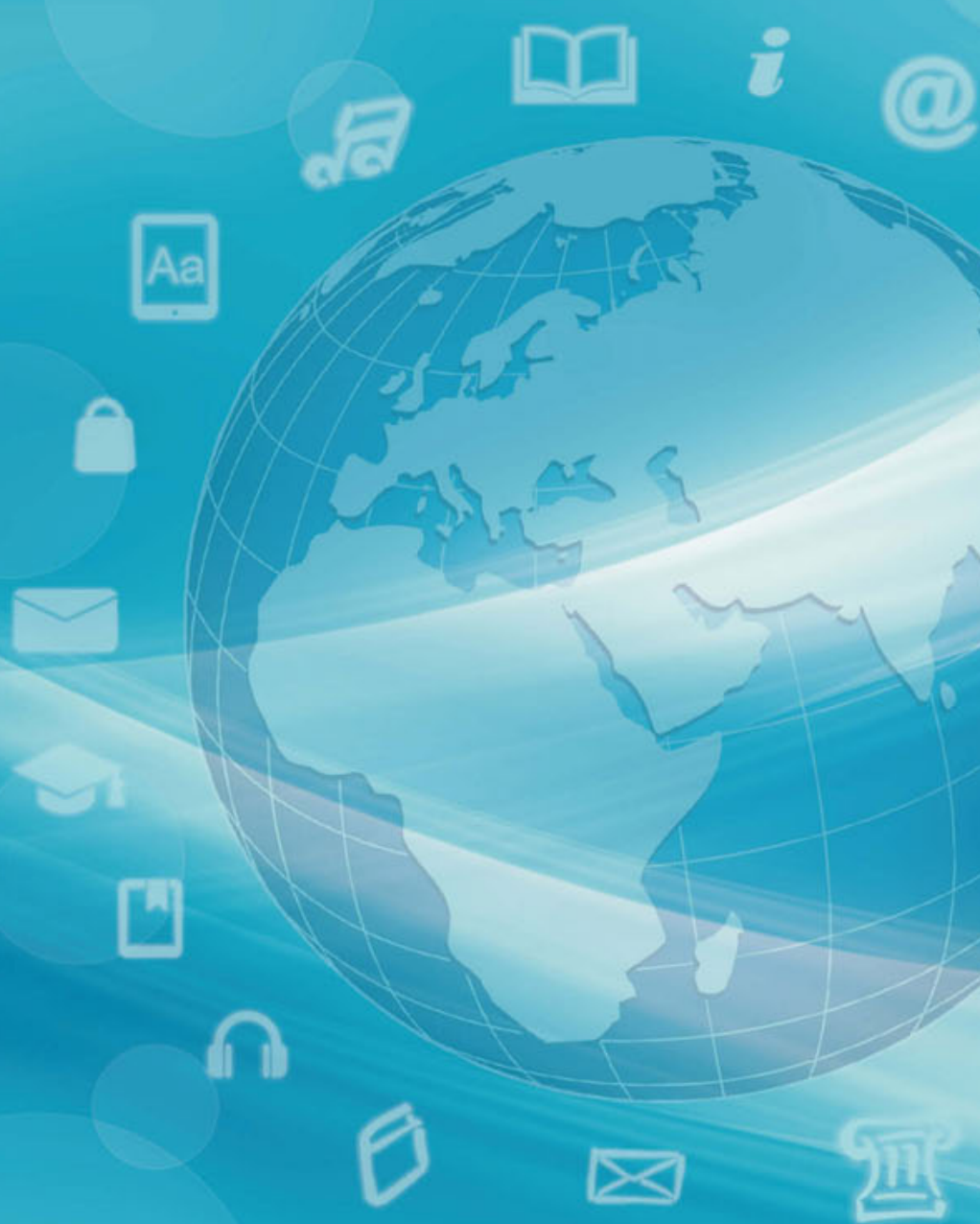

$$
\mathbb{U} \mid \begin{aligned}
& \text { WYDAWNICTWO } \\
& \text { UNIWERSYTETU ŚLASSKIEGO }
\end{aligned}
$$

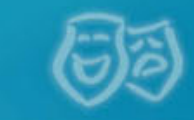




\section{International Journal of Research in E-learning}

Vol. 4 [2], 2018 


\title{
Editor-in-Chief \\ Eugenia Smyrnova-Trybulska
}

(University of Silesia in Katowice, Poland)

\author{
Vice-editor \\ Anna Studentska \\ (University of Silesia in Katowice, Poland)
}

Scientific Programme Committee

Xabier Basogain (University of the Basque Country, Spain), Sixto Cubo Delgado (University of Extremadura, Spain), Zenon Gajdzica (University of Silesia in Katowice, Poland), Bogdan Galwas (Warsaw Technical University, Poland), Tomayess Issa (Curtin University in Perth, Australia), Jana Kapounová (University of Ostrava, Czech Republic), Piet Kommers (University of Twente, the Netherlands), Stefan Kwiatkowski (Academy of Special Pedagogy, Warsaw, Poland), Josef Malach (University of Ostrava, Czech Republic), Elspeth McKay (RMIT University, Australia), Nataliia Morze (Borys Grinchenko Kyiv University, Ukraine), Tatiana Noskova (Herzen State Pedagogical University of Russia, St. Petersburg, Russia), Norbert Pachler (London University, United Kingdom), Tatiana Pavlova (Herzen State Pedagogical University of Russia, St. Petersburg, Russia), Paulo Pinto (Lisbon Lusiada University, Portugal), António dos Reis (The Graal Institute, Portugal), George Siemens (University of South Australia, University of Texas Arlington, Athabasca University, University of Manitoba), Milan Turčńni (Constantine the Philosopher University in Nitra, Slovakia), Pedro Veiga (Lisbon University, Portugal), Halina Widła (University of Silesia in Katowice, Poland), Kazimierz Wenta (Koszalin Technical University, Poland), Miroslav Zhaldak (M. P. Dragomanov National Pedagogical University in Kyiv, Ukraine)

\section{Editorial Board}

Laura Alonso Díaz (University of Extremadura, Spain), Martin Drlík (Constantine the Philosopher University in Nitra, Slovakia), Prudencia Gutiérrez Esteban (University of Extremadura, Spain), Anna Szafrańska (University of Silesia in Katowice, Poland), Olga Yakovleva (Herzen State Pedagogical University of Russia, St. Petersburg, Russia), Theodora Issa (Curtin University in Perth, Australia), Kateřina Kostolányová (University of Ostrava, Czech Republic), Ewa Ogrodzka-Mazur (University of Silesia in Katowice, Poland), Tatiana Pavlova (Herzen State Pedagogical University of Russia, St. Petersburg, Russia), Marek Rembierz (University of Silesia in Katowice, Poland), David Richardson (Linnaeus University, Sweden), Maryna Romanyukha (Dniprodzerzhinsk State Technical University, Ukraine), Magdalena Roszak (Poznań University of Medical Sciences, Poland), Iryna Sekret (Abant Izzet Baysal University, Bolu, Turkey), Urszula Szuścik (University of Silesia in Katowice, Poland), Jolanta Szulc (University of Silesia in Katowice, Poland), Anna Ślósarz (Pedagogical University of Cracow, Poland), Maciej Tanaś (Academy of Special Pedagogy, Warsaw, Poland)

\section{Editors of Thematic Issue}

Nataliia Morze, Josef Malach, Tatiana Noskova, António dos Reis, Eugenia Smyrnova-Trybulska

Proofreaders

Olga Yakovleva (Herzen State Pedagogical University of Russia, St. Petersburg, Russia - Russian Language), Anna Studenska (University of Silesia in Katowice, Poland - Polish Language), Sixto Cubo Delgado, Laura Alonso Díaz, Prudencia Gutiérrez Esteban, Gemma Delicado (University of Extremadura, Spain - Spanish Language)

\section{Statistical Editors \\ Magdalena Roszak, Anna Sowińska (Poznań University of Medical Sciences, Poland) \\ Indexed in}

ICI Journals Master List - Index Copernicus (82.36 pts), ICI Journals Master List - Index Copernicus $(\mathrm{ICV}=97.08(2017))$, ERIH PLUS, Central and Eastern European Online Library CEEOL (https:// www.ceeol.com), Academic Resource Index ResearchBib (https://www.researchbib.com/), Polska Bibliografia Naukowa (https://pbn.nauka.gov.pl), Google Scholar, The Journals Impact Factor (http:// jifactor.org/), CEJSH, BazHum, Journal Factor, CEON 


\section{Contents}

Editorial (Eugenia Smyrnova-Trybulska)

I. Evolution of Education, and Internationalisation of Education and Competences . . . . . . . . . . . . . . . 9

Nataliia Morze, Oksana Strutynska, Mariia Umryk

Implementation of Robotics as a Modern Trend in STEM Education . . 11

Lilla Koreňová, Jozef Hvorecký

Influence of University Innovative Educational Environment on the

Development of Digital STEM Competences . . . . . . . . 33

Nadiia Balyk, Galina Shmyger, Yaroslav Vasylenko

Influence of University Innovative Educational Environment on the

Development of Digital STEM Competences . . . . . . . . 45

Nadia Saleem, Aisha M Din, Saba Sadiq, Masroor Ahmed

MDB as an Effective Platform of Communication between Students and

Teachers: A Study of the Virtual University of Pakistan . . . . . . 61

II. Innovative Models, Methods, and Means in Electronical

Education . . . . . . . . . . . . . . . . . 77

Svetlana Skvortsova, Maryna Haran

The Multimedia Presentation of a Lecture as the Means of Perception,

Comprehension, and Memorisation of Educational Information by Students

Natalia Maria Ruman

The Role of Ecological Education and IT Education in Promoting

Sustainable Development of a Human Being . . . . . . . . . 107

III. Reports . . . . . . . . . . . . . . . . . . 125

Eugenia Smyrnova-Trybulska

A Report from the International Scientific Conference DLCC2018, 15-16

October 2018, Poland . 


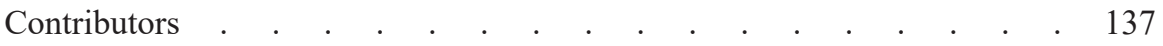

IJREL Reviewers . . . . . . . . . . . . . . . . . . 139

In the "E-learning" series . . . . . . . . . . . . . . . . 143 


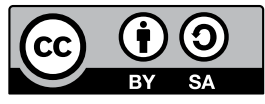

DOI 10.31261/IJREL.2018.4.2.01

\section{Editorial}

In this volume of the International Journal of Research in E-learning, authors from different countries are trying to answer the following question: what should be the university / school of the $21^{\text {st }}$ century? Among other things, it should be open to innovation - not only in the world of technology, but also in relation to teaching and learning processes. Personalisation of teaching / learning should take place - a student is in the centre of the university / school of the $21^{\text {st }}$ century. Another desirable feature is highly qualified staff, open and prepared for lifelong learning. One of the pillars of preparing new generation specialists should be STEM education, internationalisation of higher education, and mobility.

The present volume includes seven articles gathered in three chapters.

Chapter I - "Evolution of Innovative Educational Environment and Development of Digital STEM Competences" - includes four articles. At the beginning of this chapter, Nataliia Morze, Oksana Strutynska, and Mariia Umryk Ukrainian experienced authors - present the article "Implementation of Robotics as a Modern Trend in STEM Education." They state that the world revolves around innovations: new ideas, new products, new solutions to existing problems. Science, technology, engineering, and mathematics are the foundation for innovation. The development of STEM-directions in education is crucial for the development of modern society. The paper discusses implementation of STEM education in the learning process of educational institutions. The authors analyse the development of STEM education in Ukraine, determine the level of readiness of educators for understanding the principles of STEM education, and substantiate the need for introducing robotics into the educational process as a modern and important trend in STEM education. The concept of educational robotics is discussed. This makes it possible to identify the technical inclinations of students (at an early stage) and development of these inclinations, as well as formation of STEM competency in general. The study focuses on the interdisciplinary aspect of STEM education, in particular on the implementation of interdisciplinary links between STEM subjects and robotics in the conduction process of research and training projects. The authors provide examples of the implementation of robotics in the educational process based on the use of a project method. The article also delineates the project for the creation of the Juno Rover robot based on the Arduino robotic platform in 
university education and gives two examples of the robotics projects in school education; one of them is implemented on an open platform with freely distributed materials for creating and using 3D printed robots. The second manuscript "Applying QR Codes in Facilitating Mathematics and Informatics Education" - has been elaborated by Slovak researchers Lilla Koreňová and Jozef Hvorecký. They stress that QR codes are usually discussed in the context of mobile learning. In their presentation, the authors show other opportunities of their use with special focus on mathematics and informatics education and its methodology. Appropriately placed QR codes can, for example, be applied to create a feedback for both students and teachers, as an additional source of problems in a problem solver or a worksheet, or as an input gate to a didactic game. The addressees use their smartphones to read their selected QR code. The code refers to a file containing the data files predesigned and stored by their educator or the author of learning materials. The data are then used in accordance with their educator's instruction. Similarly, a QR code can link additional information sources in a worksheet or open the student's gate to the course/instructor evaluation. In the paper, such an approach is portrayed using examples from various fields of mathematics, statistics, and databases. Finally, the authors discuss advantages and disadvantages of this approach. The third article, "Influence of University Innovative Educational Environment on the Development of Digital STEM Competences" has been prepared by researchers from Ukraine - Nadiia Balyk, Galina Shmyger, and Yaroslav Vasylenko. The article deals with the problem of the influence of the innovative educational environment of the university on the development of digital STEM competences in the process of training teachers of the new formation. It is determined that the innovative educational environment of the university consists of organisational, educational, methodological, and technological and information resources, the purpose of which is to create conditions for the development of digital STEM competences of teachers. The main aspects of introduction and development of STEM education in different countries of the world are analysed. Particular attention is paid to the functioning of the STEM Centre, which is the basis of the innovative educational environment of the pedagogical university. The practical experience in introduction of STEM education at Ternopil Volodymyr Hnatiuk National Pedagogical University is summarised. The peculiarities of the influence of the innovative educational environment of the university on the development of digital STEM competences are explored. The last article in the chapter, "MDB as an Effective Platform of Communication between Students and Teachers: A Study of the Virtual University of Pakistan," has been prepared by Pakistani researchers Nadia Saleem, Aisha M Din, Saba Sadiq, and Masroor Ahmed. They stress that the integration of distance learning and Information Communication technology has brought a lot of convenience for the students who were earlier facing problems in education due to time and geographical limitations. Since the concept of e-learning is comparatively new and different, the discourse on teaching methodologies and 
the student-teacher relationship in an e-learning environment has brought many new dimensions under discussion. In a virtual system, the communication bonding between a student and a teacher is not so strong. Students are dependent on one-way communication in the form of recorded lectures, published announcements, and information given on a website. Bridging the communication gap between a student and a teacher through MDB (Moderate Discussion Board) is an effective step taken by the Virtual University of Pakistan in online education to address students. This research was aimed at investigating the effectiveness of MDB as an interaction platform between students and course instructors at the Virtual University of Pakistan. The effectiveness of MDBs was measured through analysing the number of MDBs posted in a certain course and the nature of questions asked in MDBs by students. It was a quantitative study in which two Mass Communication subjects were selected through purposive sampling. The collected data were analysed in percentages, and a statistical test Correlation was applied to find out if there was some relation between the strength of students and questions asked through MDB. The study found that although the number of MDBs is quite lower than that of enrolled students, it is an effective platform of communication between students and a teacher, as students can ask questions related to subject, exams, semester activities, and general concerns.

Chapter II - "Innovative Models, Methods, and Means in Electronical Education" - contains two articles. The authors of the first article, "The Multimedia Presentation of a Lecture as the Means of Perception, Comprehension, and Memorisation of Educational Information by Students," are Svetlana Skvortsova and Maryna Haran from Ukraine. In their manuscript, the demand for teachers of Ukrainian universities to create multimedia presentations of lectures and their use in the process of teaching the course "Methodology of teaching mathematics" has been formulated as the result of the experimental research. Taking into account the specificity of the discipline and the peculiarities of the perception, comprehension, and memorisation of educational information by students, what has been determined are the requirements for visual and audio content, for the text presented on presentation slides, and for the design and navigation, and their effectiveness has been experimentally proved. In particular, it has been established that, in order to facilitate students' perception of educational information, presentation slides should not contain large text arrays. Text slices of presentations should be executed using a certain font, with a certain font size and dominant colours of the headings and main text. To facilitate understanding and memorisation of the content of teaching, the theoretical information should be structured and presented in the form of circuits, tables, diagrams, etc. To stimulate interest in learning, a positive emotional background should be created, and thus a presentation should contain bright colour objects, photographs, and video footage of real mathematics lessons. It is emphasised that, in order to create conditions for the perception, understanding, and memorisation of educational information, presentation design 
should provide a single style of design and identical compositions of components; for example, image of the same type of information should be in the form of identical elements of "SmartArt." The second article, "The Role of Ecological Education and IT Education in Promoting Sustainable Development of a Human Being," has been elaborated by Natalia Maria Ruman from Poland. She argues that we live in times dominated by the media, which have an impact on virtually every sphere of our lives. Nowadays, it is difficult to imagine school education without the use of modern technologies such as computers or the Internet. In the context of the ecological crisis and a number of threats associated with it which are brought by contemporary civilisation - including those of conformism or materialism - it is necessary to present a series of actions taken in education to help children and their parents oppose contemporary threats. The Internet today is becoming a good tool for exploiting information. Ruman's article contains theoretical considerations on the important problems of modern civilisation and human education, namely issues related to ecology, the use of modern technologies, and communication. It focuses the reader's attention on important values in education for sustainable development.

Chapter III - "Reports" - contains the paper "A Report from the International Scientific Conference DLCC2018, 15-16 October 2018, Poland" elaborated by Eugenia Smyrnova-Trybulska, devoted to the $10^{\text {th }}$ edition of the International Scientific Conference DLCC2018: Theoretical and Practical Aspects of Distance Learning (www.dlcc.us.edu.pl). The conference was held under the theme "E-learning and smart learning environment for preparing the specialists of new generation" and included reports from the IRNet project. The conference was held on 15-16 October 2018 in Wisła. It was organised by the Faculty of Ethnology and Educational Science at the University of Silesia in Cieszyn with cooperation of ten other universities and organisations. More than 90 researchers from 10 countries and from more than 20 universities participated in this conference. It is worth noting that the conference favours exchange of experiences, strengthening international cooperation, common problem solving, implementing innovative methodologies, and creating global educational space. During the conference numerous themes were discussed, such as: further directions in international cooperation, new common scientific and didactic projects, internationalisation development in the conditions of digitalisation and globalisation. More information concerning the event can be found on the website www.dlcc.us.edu.pl. 


$$
\begin{aligned}
& \text { Evolution of Education, } \\
& \text { and Internationalisation of Education } \\
& \text { and Competences }
\end{aligned}
$$





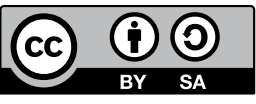

DOI 10.31261/IJREL.2018.4.2.02

\title{
Nataliia Morze
}

Ukraine (ORCID: 0000-0003-3477-9254)

\section{Oksana Strutynska}

Ukraine (ORCID: 0000-0003-3555-070X)

\section{Mariia Umryk}

Ukraine (ORCID: 0000-0002-0396-0045)

\section{Implementation of Robotics as a Modern Trend in STEM Education}

\begin{abstract}
The paper is devoted to the issues of implementation of STEM education in the learning process of educational institutions. The authors analyse the development of STEM education in Ukraine, determine the level of readiness of educators for understanding the principles of STEM education, and substantiate the need for the introduction of robotics into the educational process as a modern and important trend in STEM education. The concept of educational robotics is analysed. This makes it possible to identify the technical inclinations of students (at an early stage) and development of these inclinations, as well as formation of STEM competency in general. The study focuses on the interdisciplinary aspect of STEM education, in particular on the implementation of interdisciplinary links between STEM subjects and robotics in the conduction process of research and training projects. The authors provide examples of the implementation of robotics in the educational process based on the use of a project method. The article also includes a description of the project for the creation of the Juno Rover robot based on the Arduino robotic platform in university education and two examples of the robotics projects in school education (one of them is implemented on an open platform with freely distributed materials for creating and using $3 \mathrm{D}$ printed robots).
\end{abstract}

K e y w o r d s: robot, robotics, educational robotics, STEM, STEM education 


\section{Introduction}

The world is abundant in innovations. There are new ideas, new products, and new solutions to existing problems. Science, technology, engineering, and mathematics are the foundation for innovation. The development of STEM directions in education is crucial for the development of the modern society.

The word "STEM" means the following: $\mathbf{S}$ - Science (natural science), $\mathbf{T}$ - Technology (technologies in common understanding, not only computer technologies), $\mathbf{E}$ - Engineering (engineering and designing), and $\mathbf{M}$-Mathematics (pure science).

The world economy and the development of Ukraine are moving towards innovations. The key educational requirement to this transition is preparation of young people for creation of such innovations. Only the economy based on highperformance science and effective innovation systems can be successful in our country in the next decades. The world where our children live and learn is rapidly changing. The future is here, and it requires us and our children to be well-versed in science, technology, engineering, and mathematics.

Unfortunately, the Ukrainian innovation indicator as well as the level of technological availability of the labour force are one of the lowest compared to the remaining indicators of the country's competitiveness. These indicators are typical of the post-Soviet countries. The Global Competitiveness Index Framework is shown in Figure 1.

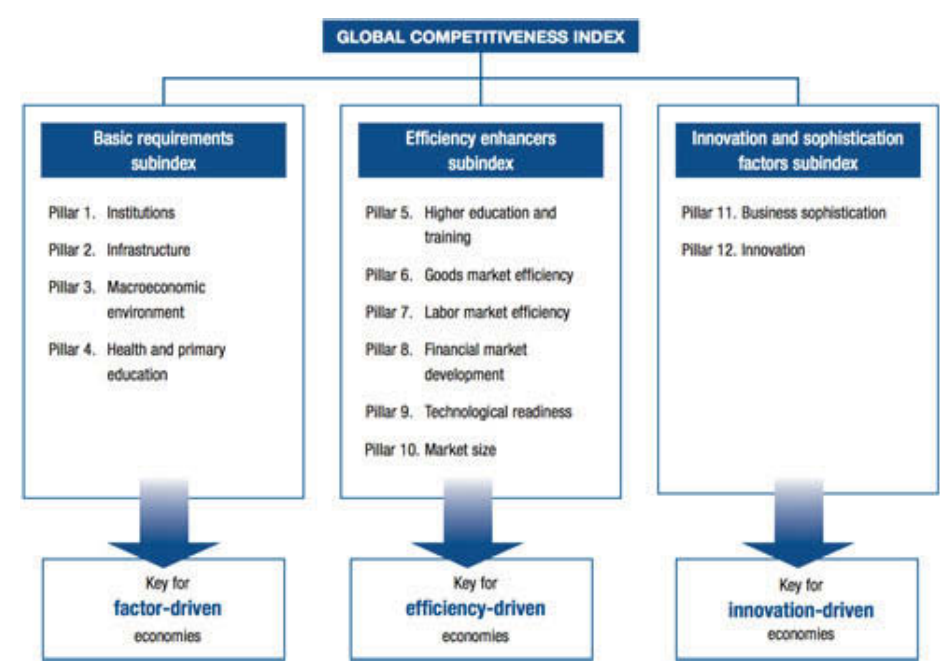

Figure 1. The Global Competitiveness Index Framework.

S o u r c e : Global Competitiveness Report 2015-2016 (Reports: World Economic Forum). Retrieved from http://reports.weforum.org/global-competitiveness-report-2015-2016/methodology, accessed 31 December 2018. 
In accordance with the Global Competitiveness Report (2018), Ukraine was ranked $83^{\text {rd }}$ out of 140 countries (see Figure 2). According to the indicator of innovation availability of this index, it was ranked $58^{\text {th }}$.

Ukraine

83 rd $_{1200}$

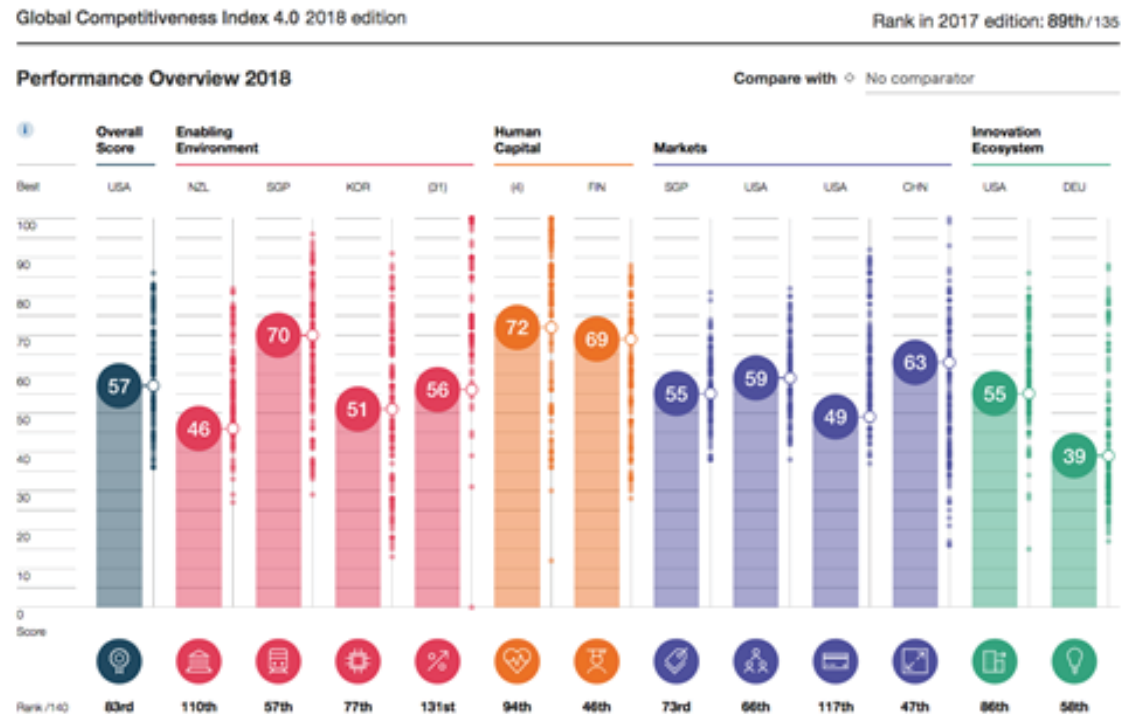

Figure 2. The Global Competitiveness Index of Ukraine.

S o u r c e : Global Competitiveness Report 2018 (Reports: World Economic Forum). Retrieved from $\mathrm{http} / /$ reports.weforum.org/global-competitiveness-report-2018/country-economy-profiles/\#economy= UKR, accessed 31 December 2018.

According to the Global Innovation Index - WIPO - Ukraine was ranked $43^{\text {rd }}$ in the world and $30^{\text {th }}$ in Europe (Dutta, Lanvin, \& Wunsch-Vincent, 2018). In accordance with the World Digital Competitiveness Index (2018), Ukraine was ranked $58^{\text {th }}$ out of 63 countries. According to the Bloomberg Innovation Index, the annual ranking of innovation in the economies of the world countries (2018), Ukraine was ranked only $46^{\text {th }}$ out of 50 countries, having dropped by four positions in a year. Our country has fallen in the ranking for the third year in a row; contrastingly, in 2015 , it took the $33^{\text {rd }}$ place.

It was recently stated at the World Economic Forum in Davos that the fourth industrial revolution was accompanied by radical changes in the labour market. The report "The Future of Employment" by the president of the forum Klaus Schwab ("The Fourth Industrial Revolution...") focuses on the fundamental transformation of the quality of life in the near future, communication, activities, and interaction of society members. In the beginning of the 2020 s, a radical change of more than $35 \%$ of the modern-day skills will lead to the disappearance of some professions, and the ones that do not yet exist will become commonplace. It was determined that 
talent (intellect) would be a more critical factor for innovation production, which would lead to a sharp increase in demand for highly skilled specialists.

In 2018, the McKinsey Global Institute's US-based prognosis revealed a potential global deficit of 140-180,000 specialists with deeper analytical skills, as well as 1.5 million managers and technology analysts in high-tech professions. Such a gap in the modern sector jobs could be measured by dozens of years.

The information society requires globally competent citizens. The global community relies on a new generation of children who will be able to:

- make a considered decision about their health and safety;

- participate in public policy and debate;

- manage their everyday life, which is increasingly associated with technologies; and

- find solutions to challenges facing the global population.

"1.2 million" vacancies in STEM were projected in 2013, which seemed to be very high. Then this figure turned into a forecast of " 2.4 million."

In order to meet the needs of the technological society and to develop the desire and ability of the population to study science and technology, the STEM direction in education should be developed at school. This is particularly important with regard to the countries with a goal of overcoming the "STEM gap" problem. This problem lies in a large number of vacancies due to the lack of skilled specialists. For example, it is believed in Finland that if young people are at the end of the school process, they will have actual practical knowledge, taking into account all the modern computer technologies and information search skills. So, even benefits for the state can be estimated and expected. Thus, there is an urgent need for the training of future teachers and for the improvement of the skills of working teachers who could implement the principles of STEM education.

A theoretical analysis of scientific papers by leading scientists and inservice teachers in the field of STEM education shows the lack of a scientifically substantiated system of teacher training for the systematic introduction of STEM education into the learning process.

The Ukrainian education is currently at the stage of developing new standards and introducing the new school concept. However, despite the fact that STEM approaches are being implemented in many Ukrainian educational institutions, now this is mainly the out-of-school STEM education, e.g., various natural, mathematical, and scientific competitions, the activities of Junior Academy of Sciences, events for students (Intel Techno Ukraine, Intel Eco Ukraine, Sikorsky Challenge Science Festival), scientific meetings, hackathons, etc. (Morze, Strutynska, \& Umryk, 2018). Therefore, it is urgent to introduce the reform of natural-mathematical and engineering education on the basis of the adaptation of foreign experience and proven foreign and domestic practices in the implementation of STEM education. 
The main components of STEM education (teaching of natural sciences, mathematics, and technologies) are also important to attract current and rapidly developing industries. Finally, this also involves robotics.

Research focus. The focus of the research is on the interdisciplinary aspects of STEM education, in particular on the implementation of interdisciplinary links between STEM subjects and robotics in the research training projects in Ukraine.

\section{Methodology of Research}

Research goals. Our goals are: analysis of the development of STEM education in Ukraine, determination of the readiness level of educators to implement the principles of STEM education, and substantiation of the need in introducing robotics into the educational process as an important component of STEM education.

This article aims at addressing the following questions:

- analysis of the theoretical research background,

- analysis of the STEM education as the most important educational trend among educators,

- analysis of the readiness level of the Ukrainian educators to implement the principles of STEM education,

- analysis of the global trend in the development of robotics as one of the current trends in the development of STEM education, and

- implementation of crossdisciplinary links between STEM subjects and robotics. The research also considers examples of the implementation of robotics in university and school education as an important component of STEM education with the use of the project method.

\section{Instrument and Procedures, Data Analysis}

Research methods. The authors have used the following research methods and tools for the investigation (2018):

- questionnaire;

- survey and interview of the Ukrainian educators;

- observation;

- documents and content analysis;

- meeting, conference, seminar, workshop, etc.; and

- analysis of the research papers. 
2,403 Ukrainian educators took part in this research. The Ukrainian educators from the target group (562 members of academic staff, 239 teachers and 1,602 students from different Ukrainian regions) were involved in this process.

The questionnaire aiming to determine the readiness level of the Ukrainian educators to implement the principles of STEM education was created during the project.

\section{Instrument and Procedures, Data Analysis}

\section{STEM Education as One of the Most Important Educational Trends among Educators}

STEM is a concept of an educational system used by developed countries in different education sectors to develop the skills necessary for children and young people to succeed in the 21 st century and to promote the innovation development of the country in general. This concept has arisen in response to the demand of business (first of all, large corporations), which requires professionals of the next level. It involves a combination of different sciences, technologies, engineering creativity and mathematical thinking.

A successful economy is based on a way of thinking that relies on innovation and creativity, research and new technological developments. Many successful entrepreneurs around the world have STEM experience, which helps them create innovative companies or develop existing ones.

In 2020 there will be a growing demand for $80 \%$ of rapidly developing professions with the need for STEM knowledge (see Figure 3). The survey of leading employers from around the world contributed to the ranking of 10 high-demand competencies up to 2020 with a prominent role in the ability and willingness to complex problem solving, critical thinking, creativity, governance, coordination, cooperation, reflection, decision-making, service orientation, negotiation, and cognitive flexibility (Hassan, 2001). The Department of Education of the United States forecasts an increase in demand for the following professions related to STEM jobs:

- biomedical engineers $-62 \%$,

- medical scientists - 36\%,

- systems software developers $-32 \%$,

- computer systems analysts - $22 \%$,

- mathematics $-16 \%$,

- all occupations $-14 \%$.

Forecast estimates show that in the 2017-2027 period the total number of STEM jobs will increase by $13 \%$, compared with $9 \%$ of non-STEM professions, especially in the sector of computing, engineering, and high-tech production. 


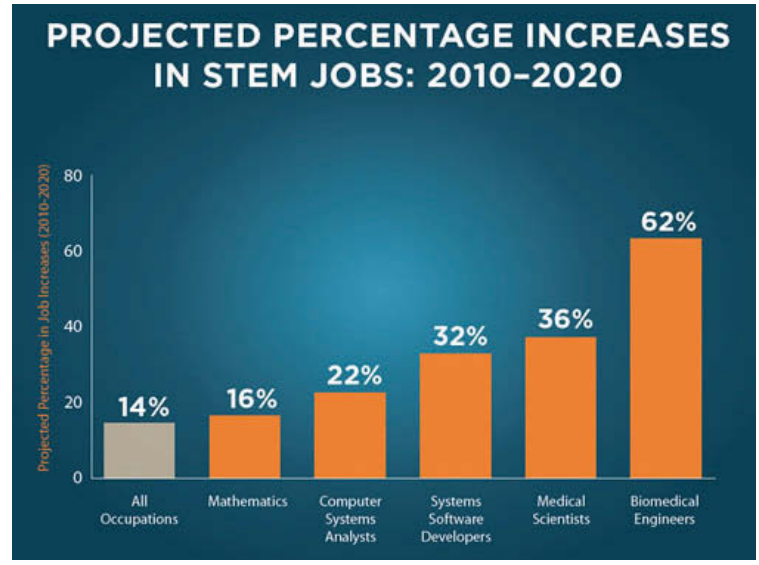

Figure 3. U.S. Department of Education.

S o u r c e : Global Competitiveness Report 2018 (Reports: World Economic Forum). Retrieved from http://reports.weforum.org/global-competitiveness-report-2018/country-economy-profiles/\#economy= UKR, accessed 31 December 2018.

STEM education is becoming one of the most important educational trends among educators. This conclusion has been reached by a number of scientists, especially involved in the research in Ukraine, which has been carried out among academic staff, teachers, and students in September 2018 (Morze, SmyrnovaTrybulska, \& Gladun, 2018). 562 members of academic staff, 239 teachers, and 1602 students took part in the survey (see Figures 4 and 5).

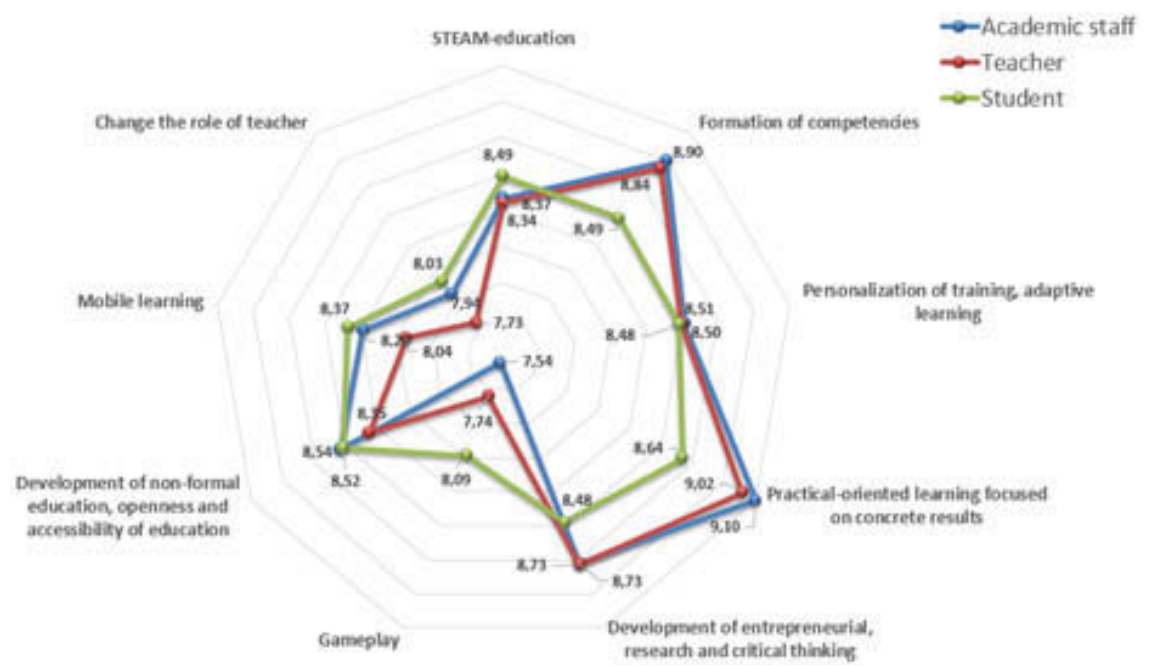

Figure 4. Results of the survey of the Ukrainian students, teachers, and professors regarding current educational trends.

S o u r c e : Own work. 
Figure 4 shows that STEM education is one of the most popular trends among the Ukrainian students, teachers, and professors. In 2017 and 2018 the authors analysed the world trends of using of ICTs in education and scientific research (Strutynska \& Umryk, 2017, 2018).

It is necessary to note that according to a 10-point scale, STEM education has obtained most points from students (8.49 points) out of 1,602 respondents. Professors and teachers give STEM education an almost equal number of points 8.37 and 8.34 out of 562 and 239 respondents respectively. The results of the survey show a high demand for STEM education and a high interest of all participants in the implementation of this kind of training. On the other hand, as already indicated, there is a low level of implementation of STEM education in the Ukrainian educational space.

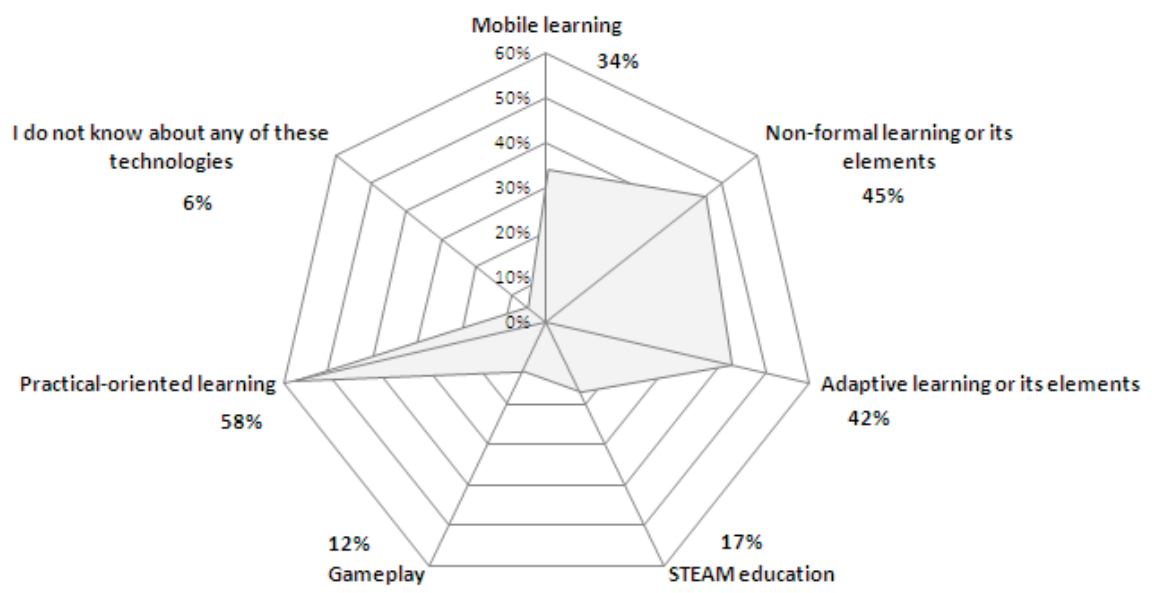

Figure 5. Results of the survey responses on innovative approaches usage in own professional activity.

S ource : Own work.

As we can see in Figure 5, STEAM education turned out to be less important than mobile learning or adaptive learning among Ukrainian students, teachers, and professors (multiple answers are possible, which is why the total responses can be more than $100 \%$ ). It means that they are less familiar with STEAM if compared with other approaches.

In order to effectively overcome this STEM gap problem, we will focus in detail on some aspects of STEM education, especially on the concept of interdisciplinarity, which is one of the key STEM points.

Interdisciplinarity in education is considered to be a pedagogical innovation (Volodchenko, Stryzhak, \& Chrapach, 2016). The key pedagogical problem in the development of STEM-oriented curriculum is the technology of integration of components. This is a combination of close disciplines as well as independent 
ontologies: science as a cognitive way to understand the world; technology as a way to improve the world sensitive to social changes; engineering as a way to design and improve devices to solve real problems; mathematics as a way of describing the world, or "the analysis of the world and real problems by the means of numbers" (Meeth, 1978).

It is necessary to note that scientists distinguish (Meeth, 1978) between several types of an interdisciplinary approach depending on the nature of the relationship between disciplines, namely:

- a crossdisciplinary approach provides consideration of one discipline through the prism of another (for example, the history of mathematics);

- a multidisciplinary approach compares several disciplines that focus on one problem, but does not combine them;

- a pluridisciplinary approach combines related disciplines (for example, physics and mathematics, or physics and engineering);

- a transdisciplinary approach goes beyond the scope of some disciplines, and focuses on a certain problem and obtaining relevant knowledge.

Therefore, the combination of the scientific method, technology, design, and mathematics is based on the educational STEM programme. It is important that the integration may result in the introduction of a separate STEM / science discipline or in some changes in the curriculum of each of the STEM disciplines based on the introduction of innovations and the enhancement of the practical component for solving real problems.

The authors take into consideration one of the sectors of STEM education development, namely robotics. The article introduces the potential foundations of robotics as a modern trend in STEM education development.

\section{Global Trends in the Development of Robotics}

Robotics is one of the world industries that is currently developing in the most intensive manner. This is evidenced by the World Robotics Report of the International Federation of Robotics (IFR) for 2018 (October 2018, Tokyo, Japan), as seen in Figure 6.

According to the results of the World Robotics Report for 2017, the new record figure for production of industrial robots has been achieved, i.e. the volume of their production has increased by $30 \%$ in comparison with the previous year. Besides that, during the last five years (2013-2017), the total sales of industrial robots doubled (see https://ifr.org/ifr-press-releases/news/global-industrial-robot-sales -doubled-over-the-past-five-years, accessed 8 December 2018). 


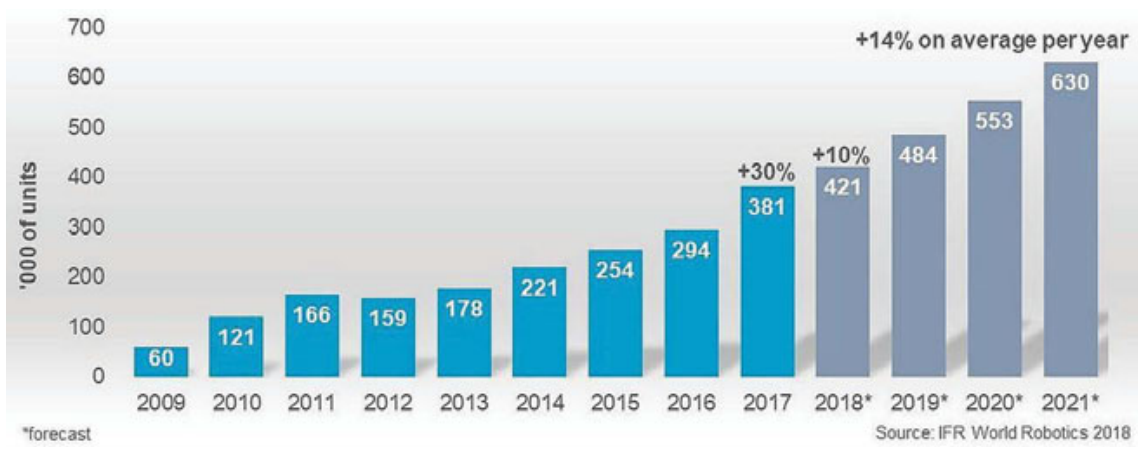

Figure 6. Estimated growth in output of industrial robot production until 2021.

S o u r c e : International Federation of Robotics. Retrieved from https://ifr.org/downloads/press2018 /Executive_Summary_WR_2018_Industrial_Robots.pdf, accessed 22 December 2018.

As of today, industrial robots and integrated automation of production are in demand in many areas of social activity:

- industry (robots for painting, welding robots, robots for cutting metal, etc.),

- military industry (military robots, intelligence robots),

- medicine (microscopic robots for use in microsurgery, robots-couriers in hospitals),

- aircraft (unpiloted robots-airplanes),

- space industry (self-propelled vehicles based on robotic systems),

- service sector (robots to help people with special needs), and

- domestic life (robotic vacuum cleaners).

Robots change the way we live and work. This also means that there is already an urgent need for specialists to design, construct, and programme robots.

\section{Educational Robotics}

The rapid development of the IT industry, robotics, and nanotechnology results in the necessity in the training of professionals. To implement this, a high-quality STEM-subject training is needed (mathematics, physics, technology, engineering, programming, etc.).

Robotics is also one of the areas for the development of the modern STEM education (Morze, Strutynska, \& Umryk, 2018). Educational process with robotics provides students with the opportunity to solve real life problems that require knowledge of STEM disciplines, in particular:

- mathematics (spatial concepts, geometry for understanding the methods of robot movement),

- physics (electronics, principles of sensors operation that constitutes the basis of robots),

- technology and design (design of devices, parts of robots, their design), and

- ICT (programming of robotics systems). 
Robotics is an applied science about the design, development, operation, and use of robots. Nowadays, increased attention is paid to robotics as to applied science, including its educational and developmental potential. This has created a new trend in education: educational robotics. Educational robotics is a crossdisciplinary area of students' learning. Its process integrates the knowledge of STEM subjects (physics, technology, mathematics), cybernetics, mechatronics, and informatics. Teaching educational robotics corresponds to the ideas of advanced training (learning the technologies that will be needed in the future) and allows students of all ages to be involved in the process of innovation, or scientific and technical creativity (Morze, Strutynska, \& Umryk, 2018).

Robotics is a popular and effective method for studying important fields of science and for designing. This is based on the active use of modern technology in production, ICT, and high intellectual level professionals who will work under the conditions of innovation economy.

Incorporation of basic knowledge on the fundamentals of robotics into school education will enable the training of specialists for future professions related to the industries that do not exist today. It is important to remember that the use of educational robotics makes it possible to identify the technical inclinations of students at an early stage and develop them in regard to the STEM competencies formation in general.

Thus, now the issue of robotics implementation in the educational process of educational institutions is of importance. The training of future specialists with regard to robotics requires updating school and university education in accordance with the present requirements.

\section{Examples of Implementation of the Robotics Fundamentals in the Educational Process}

Training in robotics fully corresponds to the principles of STEM education and is best realised by means of the project technology learning. Application of this improves formation of students' skills of team work, development of independent search and creative activities, and formation of interpersonal competencies.

There are examples of STEM-research projects, related to robotics in university and school education.

\section{An example of a research training project in university education}

For the implementation of research projects on robotics in university education, it is proposed to use freely distributed materials from open robotics platforms. For example, the project described in this article uses the materials of the open platform thingiverse.com for 3D printing of robots (ExploreMaking, 2016). As part of the open platform support, all projects have Creative Commons licence, which means that anyone can use or modify any product design that has already been developed.

The research project includes design, 3D part printer work, Juno Rover assembly, and programming based on the Arduino platform (Figure 7). 


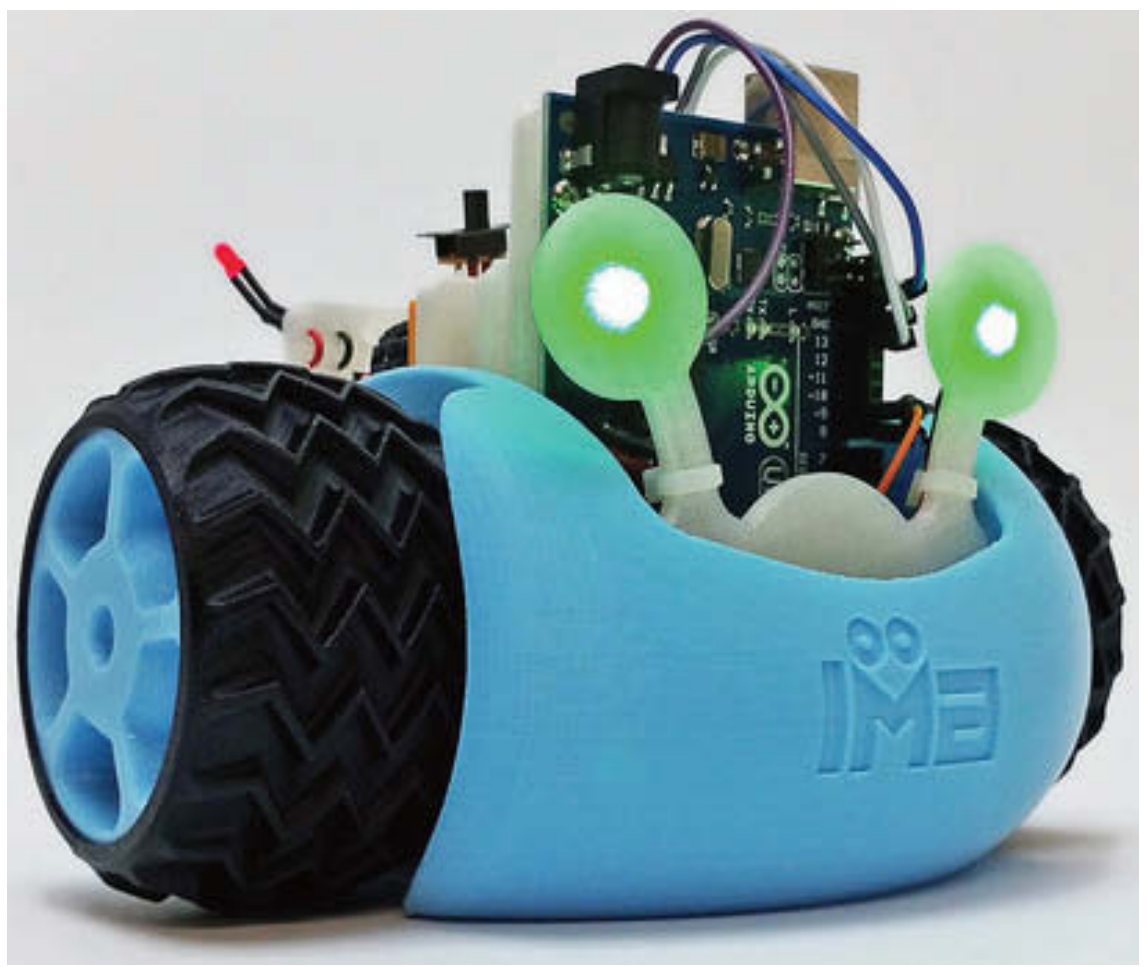

Figure 7. The exterior of Juno Rover robot on the basis of the robotic platform Arduino by ExploreMaking.

S o u r c e : Thingiverse (Juno Rover). Retrieved from https://www.thingiverse.com/thing:1720394, accessed 22 December 2018.

The robot design is made with the use of SolidWorks software package. The peculiarity of the robot is its $3 \mathrm{D}$ parts. They are optimised and designed for printing on any desktop 3D printer.

Work within the research project begins with printing the details of the robot on a 3D printer. The estimated total print time for the Juno Rover is set to 15 hours. Project participants print housing, panels, wheel disks, and tires. Tire covers are made of special Elastan flexible plastic.

In the lower part of the case, the robot provides a battery compartment, and in its upper part it has slots for panels. By using the free online version of the SolidWorks product, project participants can also design additional robot modules, expanding their functions. These modules will be installed in the slots on the panel and connected to the Arduino Uno platform.

For the robot assembly, it is necessary to use electronic cards: Arduino Uno, Bluetooth module, switch, LEDs, holder for 4xAA batteries, spin connectors, shrink tubing, plastic clamp, etc. 
After a successful collection, the programming stage begins (coding). The Juno Rover can be programmed with the use of a smartphone via the Bluetooth module connected to the Arduino Uno platform. Programming "behaviour" of the robot can be done using the online Arduino web editor (www.arduino.cc), as seen in Figure 8. It is also convenient to keep all developments in the cloud with all Arduino built-in libraries.

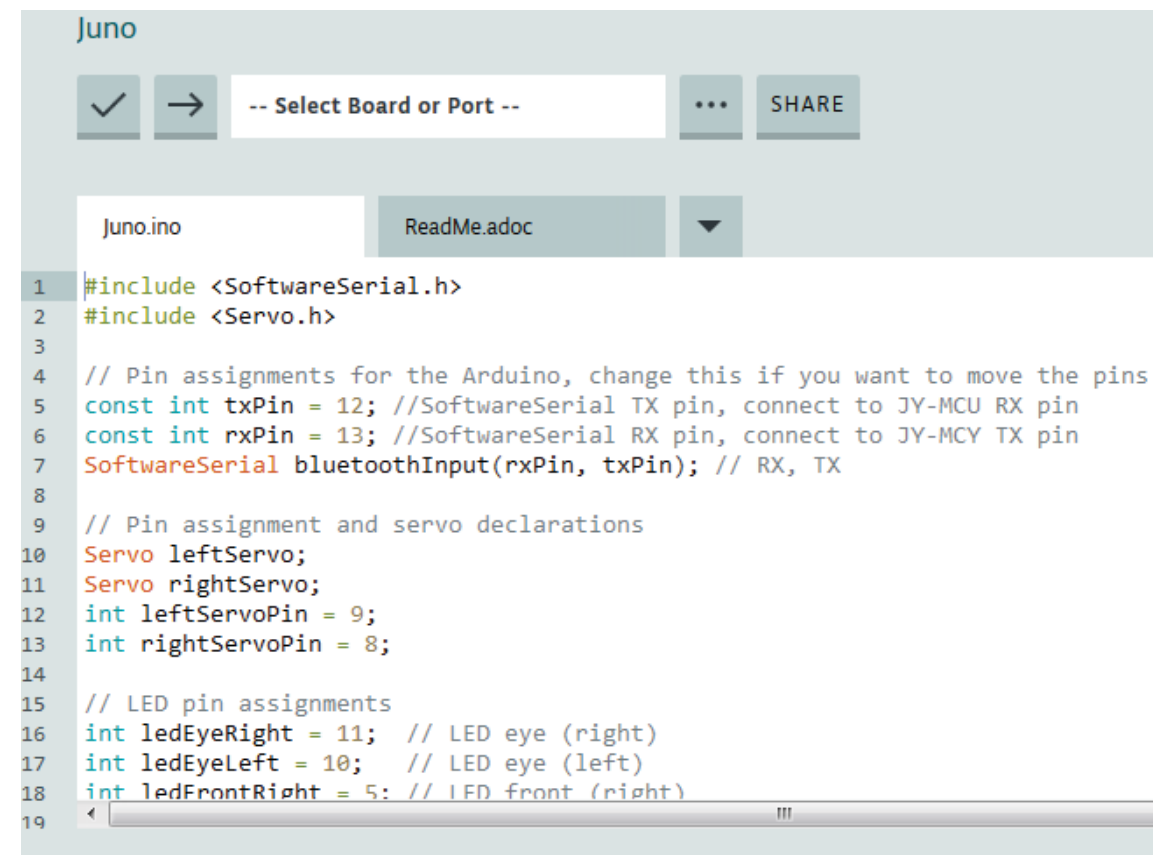

Figure 8. An example of code for the programming of Juno Rover robot based on the Arduino Uno platform.

S our c e : Own work.

Successful completion of the project consists in:

- implementing the robot assembly;

- working out the code for the robots to make their movements forward, backwards, and turns;

- developing full project documentation; and

- designing additional robot modules.

An example of a research training project in secondary school education

One of the examples of research projects on robotics is Poppy Project (https:// www.poppy-project.org/en, accessed 17 December 2018). This project is also implemented as an open source platform with freeloading materials for the creation and use of 3D printed robots. The resources of the platform are proposed for educators, artists, scientists, and hackers. 
One of the interesting projects of the platform is Poppy Ergo Jr (https://www .poppy-project.org/en/robots/poppy-ergo-jr, accessed 17 December 2018), which can be used effectively in school education, since it is possible to programme a created robot in a visual programming system Scratch. This is envisaged in the Ukrainian school computer science course starting from 2013.

The open-source Poppy Ergo Jr robot has been developed by the Flowers lab at Inria (France). The use of educational platforms like Poppy Ergo Jr was added to the French lower secondary curriculum for autumn 2016 for teaching computer science and robotics.

The Poppy Ergo Jr robot is a small 6-degrees-of-freedom robot arm. It is made of 6 cheap motors (XL-320 Dynamixel servos) with simple 3D-printed parts (Figure 9).

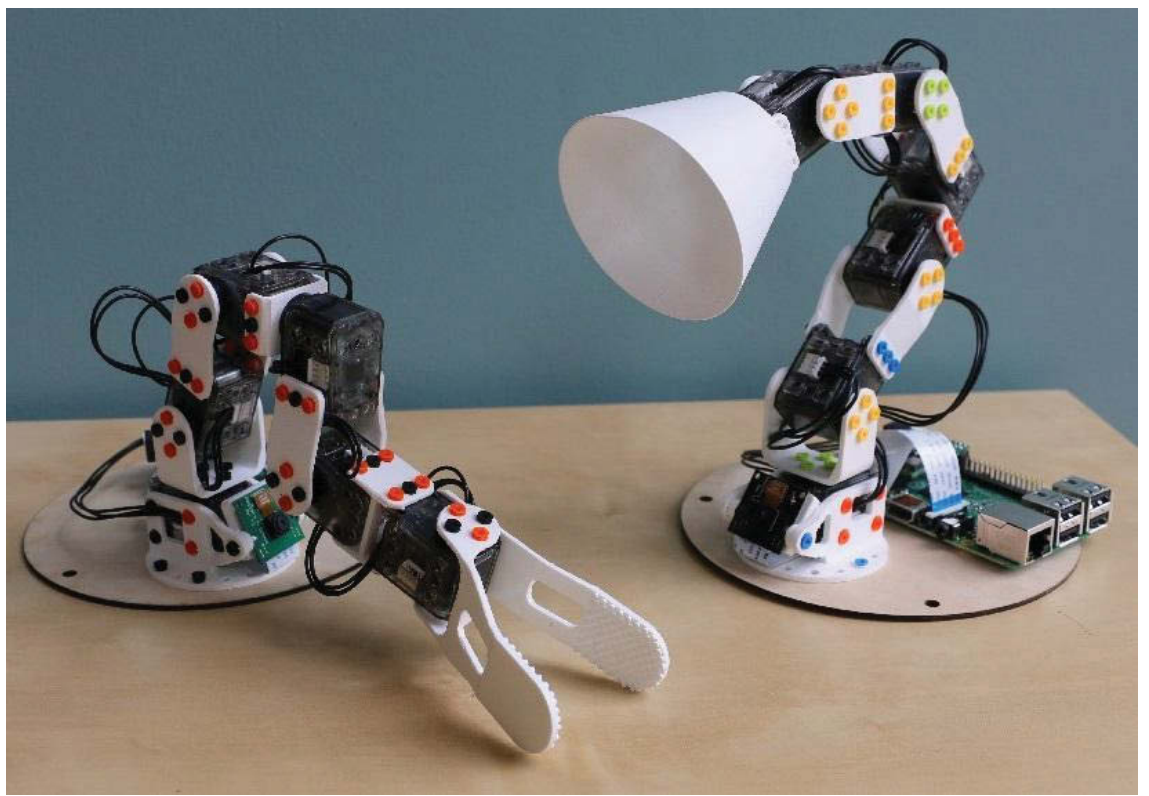

Figure 9. The exterior of Ergo Jr robot based on Raspberry Pi robotic platform.

S o u r c e : Poppy Project (Ergo Jr). Retrieved from https://www.poppy-project.org, accessed 22 December 2018.

The project consists of the following stages:

1) printing parts of the robot on $3 D$ printer;

2) designing a robot arm with the use of $3 \mathrm{D}$ printed parts, robotic platform, and other details; and

3) coding a robot arm.

The peculiarity of such projects lies in the students' need to work with the following technologies: 
- use of 3D technology (basic knowledge and skills in using 3D slicer software for printing 3D models, and work with 3D printers);

- work on robotic platforms such as Arduino, Raspberry Pi; and

- robotic platforms programming, for instance Poppy Ergo Jr robot programing needs the use of the visual programming system Snap! (a variant of Scratch) or Scratch (see Figure 10).

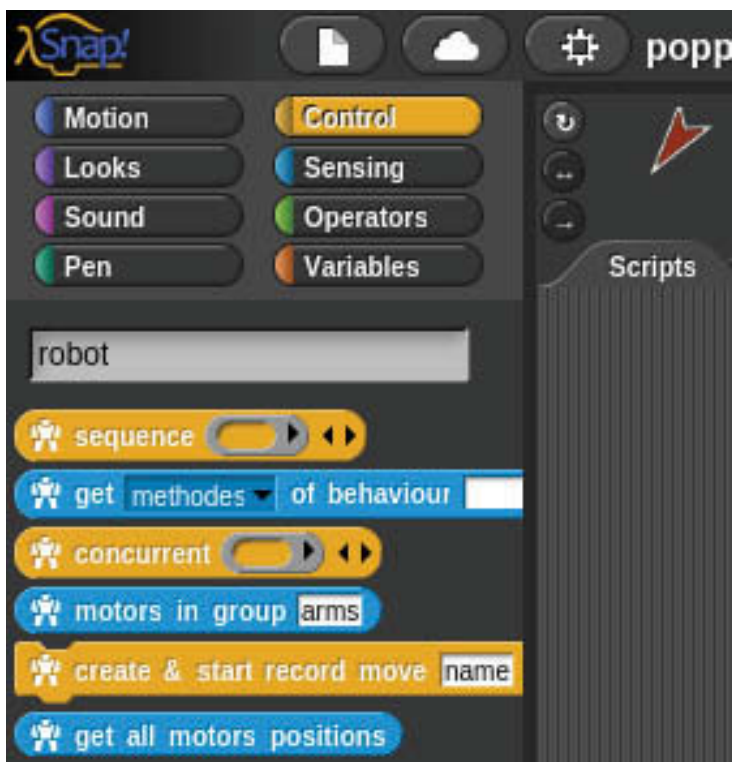

Figure 10. An example of code for the programming of Ergo Jr robot using a visual programming system Snap!

S o u r c e : Own work.

It is obvious that students need the knowledge and skills of STEM subjects. For example, in the process of Poppy Ergo Jr project, students use pre-acquired knowledge from:

- mathematics (spatial awareness and movement);

- computer science (networks, 3D technology, understanding computer network functions and how 3D printing works);

- modelling, engineering, physics, robotics (creation of a technological object, and analysis of its structure and how it functions);

- coding (knowledge of programming, how to create, write, and execute a computer programme); and

- design (using or creating illustrations, robot parts design).

Besides that, there is formation of pupils' skills in collaborative creation of a communicating object prototype. Thus, the crossdisciplinary connections of STEM are realised (robotics and 3D technologies). 


\section{An example of a research training project in primary school education}

Another example of a research training project on robotics in primary school is a scientific all-terrain vehicle. This project can be realised using different robotics platforms. In our own professional activity, we used a robotics platform Makeblock (see Figure 11).
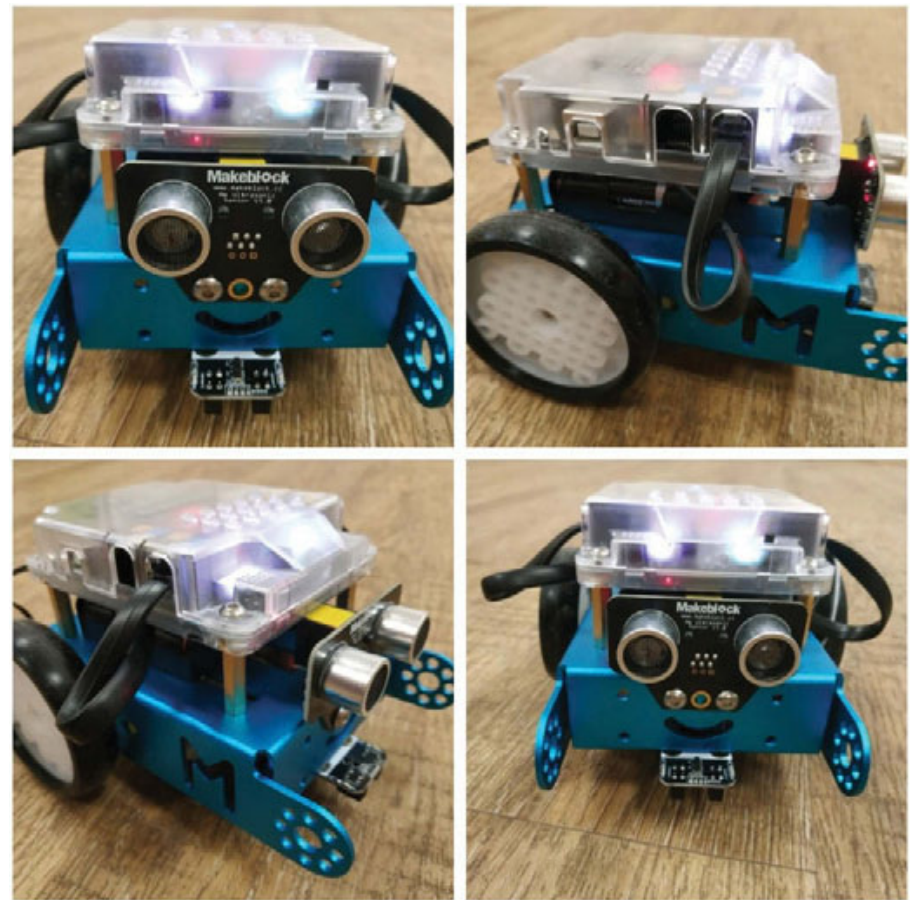

Figure 11. An example of a scientific all-terrain vehicle constructed by primary school pupils.

S o ur c e : Own work.

This project can teach students the various ways in which scientists and engineers can explore hard-to-reach places, including distant planets. The training project includes constructing, programming Makeblock, and checking code to make robot' movements forward, backwards, and turns. An example of code is seen in Figure 12. 


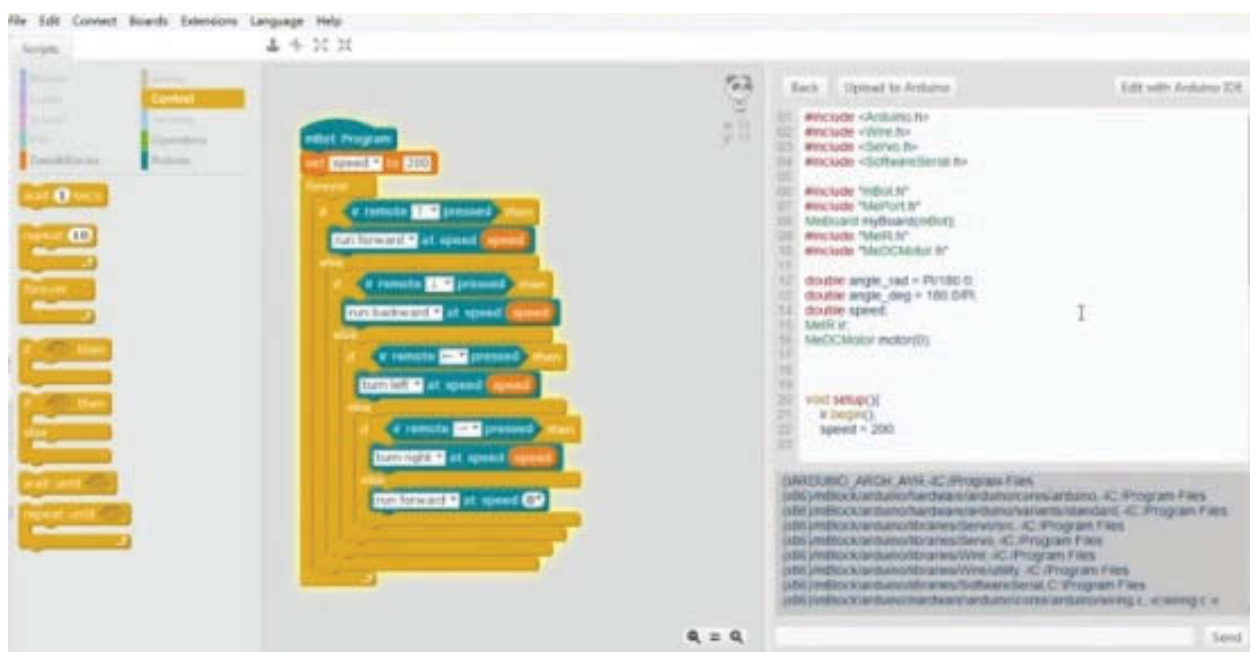

Figure 12. An example of code for the programming of a scientific all-terrain vehicle using a visual programming system mBlock.

S o u r c e : Own work.

As a result of the training project, primary school pupils obtain the knowledge and skills in such STEM subjects as technology, programming, physics, and robotics.

As was discussed above, we can make tentative conclusions about research training projects in university and school education. Therefore, the project activity embodies the priority trends of the modern education to the integration of the subject disciplines.

Implementation of these projects contributes to the formation and development of the following (Morze, Strutynska, \& Umryk, 2018):

- cooperation skills;

- complex problem solving skills;

- research skills;

- critical and creative thinking;

- ability to analyse, synthesise, critically estimate, and present information; and

- ability to obtain and practically use knowledge and skills in the design process. In addition, there is an obvious crossdisciplinary aspect of the implementation of such projects as integration of several subjects in the implementation of projects using 3D technology and robotic platforms. 


\section{Discussion}

Thus, the paper addresses the following issues:

- analysing the STEM education development in Ukraine;

- determining the readiness level of educators for understanding the STEM education principles;

- implementing the crossdisciplinary aspect of STEM education and, as a result, increasing the technological availability of the future specialists; and

- introducing robotics into the educational process based on the use of the project methodology.

According to the research conducted, the authors propose several ways to improve the development level of the STEM education implementation for different target groups of Ukrainian educators (academic staff, teachers, and students):

a) increase of the awareness of some educators' groups regarding different aspects of the STEM education (for all targets groups);

b) implementation of crossdisciplinary links between STEM disciplines and robotics through implementation of the research projects (for all target groups);

c) update of curricula for future teachers through the inclusion of the STEM approach and robotics (for students);

d) trainings for educators regarding implementation of the STEM approach in the academic process (academic staff and teachers); and

e) development of the methodology for teaching STEM, based on the use of innovation technologies, in particular IBL and 5E models, and purposeful skills development.

In order to increase the level of technological availability in the society, it is necessary to develop STEM in education starting from school time, not as a separate discipline, but through well-founded integration and crossdisciplinarity based on the use of pedagogical innovation technologies such as PBL and IBL. It is proposed to teach STEM and robotics through training research projects, by means of integrated faculty courses or by including such projects in a school-based course in informatics and technology. To eliminate the STEM gap in university education, we suggest incorporating STEM education elements into separate disciplines and then engaging students in research projects. Moreover, what is suggested is the elaboration of an appropriate training method based on the use of 5E model and purposeful skills development of all participants of the educational process. This is the target of further development of the described research. 


\section{Conclusions and Perspectives for Further Research}

The results of the survey show the willingness and motivation of the Ukrainian educators to use STEM approaches in the educational process. However, a theoretical analysis of scientific papers by leading experts in the field of STEM education, studying the experience of teachers, shows that there is no scientifically substantiated system for training teachers to prepare them for the systematic introduction of STEM education into the educational process on the basis of the appropriate methodology.

Overcoming the STEM gap needs correct identification of areas for further research which include:

- awareness improvement and development of techniques for using the STEM approach in the educational process,

- understanding of the conditions for the introduction of educational robotics into the process of training for future teachers of natural sciences (informatics, mathematics, physics) as a promising direction of STEM,

- development of an appropriate training method based on the use of 5E model, and

- purposeful skills development of all participants of the educational process.

The quality upgrading of STEM education could be reached through the improvement of curricula for future teachers of informatics, mathematics, or physics and the implementation of crossdisciplinary links between STEM disciplines, robotics, and related industries.

One of the points of our future work is to elaborate a new survey for the Ukrainian educators to define their needs in STEM education and robotics.

\section{References}

Dutta, S., Lanvin, B., \& Wunsch-Vincent, S. (2018). Global Innovation Index 2018. Energizing the world with innovation. Accessed 18 December 2018. Retrieved from https://www.wipo.int/edocs /pubdocs/en/wipo_pub_gii_2018.pdf.

Executive summary World Robotics 2018 Industrial Robots. Accessed 8 December 2018. Retrieved from https://ifr.org/downloads/press2018/Executive_Summary_WR_2018_Industrial_Robots.pdf.

ExploreMaking. (2016). Juno Rover: Intro to electronics and coding. Thingiverse. 15 August 2016. Accessed 17 December 2018. Retrieved from https://www.thingiverse.com/thing:1720394.

Hassan, I. H. (2001). From postmodernism to postmodernity: The local/global context. Philosophy and Literature, 25(1), 1-13. DOI: 10.1353/phl.2001.0011. 
International Federation of Robotics. Global industrial robot sales doubled over the past five years. Accessed 8 December 2018. Retrieved from https://ifr.org/ifr-press-releases/news/global -industrial-robot-sales-doubled-over-the-past-five-years.

Meeth, L. R. (1978). Interdisciplinary studies: Integration of knowledge and experience. Change, $10,6-9$.

Morze, N., Smyrnova-Trybulska, E., \& Gladun, M. (2018). Selected aspects of IBL in STEMeducation. In: E. Smyrnova-Trybulska (Ed.), E-learning and smart learning environment for the preparation of new generation specialists. E-learning series, volume 10 (pp. 361-379). Katowice-Cieszyn: University of Silesia, Studio Noa.

Morze, N., Strutynska, O., \& Umryk, M. (2018). Osvìtnâ Robototehnìka Âk Perspektivnij Naprâm Rozvitku Stem-Osviti /Educational robotics as a prospective trend in STEM-education development/ (in Ukrainian). In Open Educational E-environment of Modern University, 5. Accessed 22 December 2018. Retrieved from http://openedu.kubg.edu.ua/journal/index.php /openedu/article/view/175/233\#.XCValfmLTcs.

Poppy Project - Ergo Jr. Accessed 17 December 2018. Retrieved from https://www.poppy-project .org/en/robots/poppy-ergo-jr.

Strutynska, O. V. \& Umryk, M. A. (2017). ICT tools and trends in research, education and science: Local survey. Open educational e-environment of modern University, 3, 150-160. Accessed 17 December 2018. Retrieved from http://openedu.kubg.edu.ua/journal/index.php/openedu/article /view/79/112\#.Wdys_4-0Pcs.

Strutynska, O. \& Umryk, M. (2018). Analysis of development level of the certain digital competences of the Ukrainian educators. In E. Smyrnova-Trybulska (Ed.), E-learning and smart learning environment for the preparation of new generation specialists (pp. 293-315). Katowice-Cieszyn: University of Silesia, Studio Noa. Retrieved from http://ig.studio-noa.pl/pub/us/E-1-10/10-615 .pdf.

The Fourth Industrial Revolution, by Klaus Schwab. Accessed 18 December 2018. Retrieved from https://www.weforum.org/about/the-fourth-industrial-revolution-by-klaus-schwab.

Volodchenko, A. Y., Stryzhak, O. Y., \& Chrapach, H. S. (2016). Transdisciplìnarnij harakter operacìonal'nostì rozvitku obdarovanostì učnìvs'koï molodì /Transdisciplinary nature of the development of giftedness of school youth/ (in Ukrainian). Navčannâ ta vihovannâ obdarovanoï ditini: teoriâ ta praktika /Teaching and Upbringing of a Gifted Child: Theory and Practice/, 16, 100-110. Retrieved from: http://irbis-nbuv.gov.ua/cgi-bin/irbis_nbuv /cgiirbis_64.exe?C21COM=2\&I21DBN=UJRN\&P21DBN=UJRN\&IMAGE_FILE_ DOWNLOAD=1\&Image_file_name=PDF/Nivoo_2016_1_13.pdf.

Nataliia Morze, Oksana Strutynska, Mariia Umryk

\section{Wprowadzanie robotyki jako współczesnego trendu w edukacji STEM}

\section{Streszczenie}

Artykuł poświęcono kwestii wprowadzania edukacji STEM (edukacji w zakresie nauki, technologii, inżynierii i matematyki) w procesie uczenia się w instytucjach edukacyjnych. Autorzy analizują rozwój edukacji STEM na Ukrainie, określają poziom gotowości edukatorów do zrozumienia głównych zasad edukacji STEM, konkretyzują potrzebę wprowadzenia robotyki do procesu edukacyjnego jako współczesnego i ważnego trendu w edukacji STEM. Zanalizowano pojęcie robotyki edukacyjnej. 
To umożliwia zidentyfikowanie (na bardzo wczesnym etapie) oraz rozwijanie zdolności technicznych, jak również formowanie ogólnych kompetencji STEM. Przedstawione badanie koncentruje się na interdyscyplinarnym aspekcie edukacji STEM, a szczególnie na wprowadzeniu interdyscyplinarnych powiązań między przedmiotami, które obejmuje edukacja STEM a robotyką w prowadzeniu badań i projektów szkoleniowych. Autorzy przedstawiają przykłady wprowadzenia robotyki do procesu edukacyjnego opierając się na metodzie projektów. Podano opis projektu tworzenia robota Juno Rover w oparciu o platformę Arduino oraz Projekt Poppy realizowany w edukacji szkolnej, który wprowadza otwartą platformę zawierającą rozprowadzane za darmo materiały edukacyjne poświęcone tworzeniu oraz wykorzystaniu robotów tworzonych z wykorzystaniem drukarki 3D.

S łow a kluc zow e: robot, robotyka, robotyka edukacyjna, STEM, edukacja STEM

Nataliia Morze, Oksana Strutynska, Mariia Umryk

\section{Внедрение робототехники как современного направления в STEM- образовании}

Анн но т ация

Статья посвящена вопросам внедрения STEM-образования в учебный процесс образовательных учреждений. Авторы анализируют развитие STEM-образования в Украине, определяют уровень готовности педагогов к пониманию принципов STEM-образования, обосновывают необходимость внедрения робототехники в образовательный процесс как современного и важного направления в обучении STEM. Анализируется концепция образовательной робототехники. Это делает возможным выявление технических способностей студентов (в раннем возрасте) и развитие этих способностей, а также формирование STEM-компетентностей в целом. Исследование фокусируется на междисциплинарном аспекте обучению STEM, в частности на реализации междисциплинарных связей между предметами STEM и робототехникой в процессе проведения исследовательских учебных проектов. Авторы приводят примеры внедрения робототехники в учебный процесс на основе использования метода проектов. Представлено описание проекта создания робота Juno Rover на основе роботизированной платформы Arduino в университетском образовании. Также приведены примеры робототехнических проектов в школьном образовании, один из которых реализуется на открытой платформе со свободно распространяемыми материалами для создания и использования роботов с использованием 3D-технологий.

К л ю ч в в ы е с ло в а: бихевиоризм, конструктивизм, электронное обучение, смешанное обучение, цифровая среда, IRNet 
António Manuel Diogo dos Reis, Olga Yakovleva, Eugenia Smyrnova-Trybulska, Nataliia Morze

\section{Implementación de la robótica como una tendencia moderna en Educación CTIM}

\section{Resumen}

El trabajo versa sobre la implementación de la Educación CTIM en el proceso de aprendizaje de las instituciones educativas. Las autoras analizan el desarrollo de la Educación CTIM en Ucrania, determinan también el nivel de preparación de los docentes para comprender los principios de la Educación CTIM, y justifican la necesidad de introducir la robótica en el proceso educativo como una tendencia moderna e importante de la Educación CTIM. Se analiza el concepto de robótica educativa para identificar los intereses técnicos del alumnado (en las primeras etapas) en estos temas, así como la formación de la competencia en Educación CTIM. El estudio se centra en los aspectos interdisciplinares de la Educación CTIM, en particular en la implementación de los vínculos interdisciplinares entre los temas CTIM y la robótica en el proceso de desarrollo de proyectos de formación e investigación. Las autoras proporcionan ejemplos de implementación de la robótica en el proceso educativo basado en métodos basados en proyectos. Se describe el proyecto basado en el desarrollo del robot Juno Rover, robot desarrollado en la plataforma Artuino. También se describen dos ejemplos de aplicación de la robótica en los centros educativos. Uno de ellos es la implementación en una plataforma abierta, con materiales de distribución gratuita, para crear y utilizar robot impresos en 3D.

P a la bra s c lave: robot, robótica, robótica educativa, CTIM, educación CTIM 


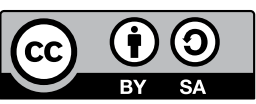

DOI 10.31261/IJREL.2018.4.2.03

\title{
Lilla Koreňová
}

Slovakia (ORCID: 0000-0001-6103-531X)

\section{Jozef Hvorecký}

United Kingdom (ORCID: 0000-0002-5948-1676)

\section{Applying QR Codes in Facilitating Mathematics and Informatics Education}

\begin{abstract}
QR codes are usually discussed in the context of mobile learning. In our article, we show other opportunities of their use with special focus on mathematics and informatics education and its methodology. Appropriately placed QR codes can, for example, be applied to create a feedback for both students and teachers, as an additional source of problems in a problem solver or a worksheet, or as an input gate to a didactic game. The addressees use their smartphones to read their selected $\mathrm{QR}$ code. The code refers to a file containing the data files predesigned and stored by their educator or the author of learning materials. The data are then used in accordance with their educator's instruction. Similarly, a QR code can link additional information sources in a worksheet or open the student's gate to the course/instructor evaluation. In the paper, we portray such an approach using examples from various fields of mathematics, statistics, and databases. Finally, we discuss advantages and disadvantages of this approach.
\end{abstract}

K e y w o rds: QR code, educational technology, mobile learning, distance education 


\section{Introduction}

Schools have to respond to the development of technology. In our article, we study the application of QR codes in education. Various forms in which they may add a value to teaching and learning processes are identified and exemplified.

According to Andrew Ramsden (2008, p. 2), under the QR (Quick Response) code we understand "a two dimension bar code that can be read on devices such as a mobile device (camera phone) or a laptop computer which, once accessed, will allow you to complete an action." The code, therefore, primarily serves as an input to a mobile device - a smartphone or a laptop. The device reads and encodes it. As a final result, the message hidden in the QR code activates the receiving device and ignites its activity. The activity is usually stored on the Internet.

From a general point of view, the entire process consists of three basic steps:

- The mobile phone contains an application capable of recognising and reading QR codes. When the application is running and the device's camera is pointed to a QR code, the encoded information enters the device.

- The device accesses the file specified by the code. (The file must be available on the Internet and its URL address must coincide with the result of decoding.) The application opens the file. In accordance with the type of the file, it may display its data (text, pictures, videos, etc.) or start executing the stored programme.

- In the latter case, the programme takes control over the device (over its screen, keyboard, etc.) If the programme is interactive, the user can communicate with it.

For educators, it means that they can exploit the QR codes in two basic ways. First, they can prepare data files in which announcements of any kind (time schedules, notices, assignments, and so on) are stored. This approach exploits only first two steps specified above. The gained information is static and can be used primarily in the read-only mode.

In our article, we concentrate on the second option - the QR code activates interactions between the programme and its user. This option makes it possible to form an educational environment for active learning. When properly designed and implemented, learners can be instructed by means of, for example, strategies typical of constructivist methodologies i.e. they can be guided to collaborate in building their knowledge (Silberman, 1996; Tóthová, Kostrub, \& Ferková, 2017). 


\section{Using QR Codes in Educational Applications: A Brief Overview}

The authors support the standpoint of Hsin Chih Lai et al. (2013), who understand the use of QR codes in education as a potential expansion of the learning space. The expansion moves to all directions: time, space, and type of the delivered "lessons." Moving in time and space means that anyone reading the barcode can reach its content. The type of delivered material is only limited by the available IT. It can consist of text, sound, video, interaction with the user, etc. Advanced versions can ignite procedures like augmented reality, virtual environments, etc. According to Sabrina Leone (2015, p. 2628), "since learning takes place in many contexts, formal, non-formal and informal, inclusive and quality education become synonyms and are vital for the development of more inclusive societies."

Traditionally, education is performed in classrooms. Even in this environment, QR-based approaches have a quite long tradition (see, for example, Curtis et al., 2002). However, their intensive exploitation is a recent phenomenon related to the widespread use of needed technology. Teaching and learning are moved beyond their traditional limits, and the reasons for it are obvious: appropriate technology is now easily available and less expensive, and with its wider saturation in schools the educators are learning its capability, including its advantages and drawbacks.

However, the technology itself does not suffice. The concept is not well known yet (Chicioreanu, Bilal, \& Butnariu, 2015). The educators must be not only willing to use it (Abas, Yahya, \& Kamaruddin, 2015), but also adequately prepared, that is, trained. The instructions like that of Ramsden (2008) explain the process of the implementation, but do not motivate teachers enough to create their own applications. Below we show how such environments can be prepared by professionals or passionate laymen and later exploited by anyone. We are supporters of the idea that - similarly to the textbook preparation - QR code based applications should be made by highly qualified individuals and teams to ensure their quality. Teodora Daniela Chicioreanu, Essaid Bilal, \& Monica Butnariu (2015) exemplify parts of learning processes which can be transmitted using QR codes:

- the educator's contact information;

- access to required or additional resources;

- syllabi, course handouts, assignments, and tutorials;

- tests and their sample solutions; and

- social and community activities (team-building, invitations to school events, polls and voting, virtual tours, ...).

The last item illustrates how outdoor activities can be promoted using QR codes. A typical example is posting QR code based information at historical monuments or other points of interest (Bohumelová \& Hvorecký, 2015). Their 
activation delivers relevant information to the visitors, often in several forms and formats. The educational value of such an approach is indisputable and presents QR codes as a considerable tool for life-long education.

\section{QR Codes as Links to Learning Materials}

The main feature of QR codes is their ability to refer to distant (Internetbased) information sources. This attribute can be utilised by educators in various situations. The authors employed the access to Internet information via QR addressing different categories of audience. Below are typical examples.

\section{Teacher Manual}

The book by Lilla Koreňová (2015) explores the use of QR codes for addressing external information that can hardly be reached in traditional textbooks. Her book addresses in-service and pre-service mathematics teachers. Due to QR codes, she can consider animation as a supportive tool in her explanations - something impossible in standard textbooks. Because of low familiarity with this concept among older teachers, the book introduction also explains ways of purchasing and implementing relevant software for mobile phones. It addresses two most popular systems - Android and iPhone - as well as a desktop QR code reader.

The book also discusses a variety of external educational software products for pupils and students. Due to their easy reach via QR codes, the teachers can quickly access them and test their relevance to their educational aims and methods.

For a full use of textbook ideas, Geogebra software is required. The text contains instructions on reaching and implementing it, too. The process can be done using a QR code (see Figure 1).

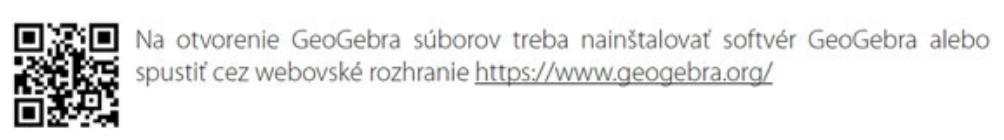

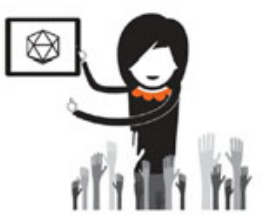

Materiály

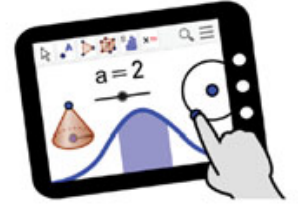

Start GeoGebra

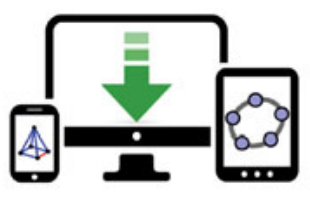

Downloads

Figure 1. QR code support for installing Geogebra.

S o u r c e : Koreňová, 2015. 
Geogebra itself contains many problems which can be incorporated by teachers in their education. The textbook refers to them, too (see Figure 2).

\section{Webstrán|ka tohto softvéru je https://www.geogebra.org/}

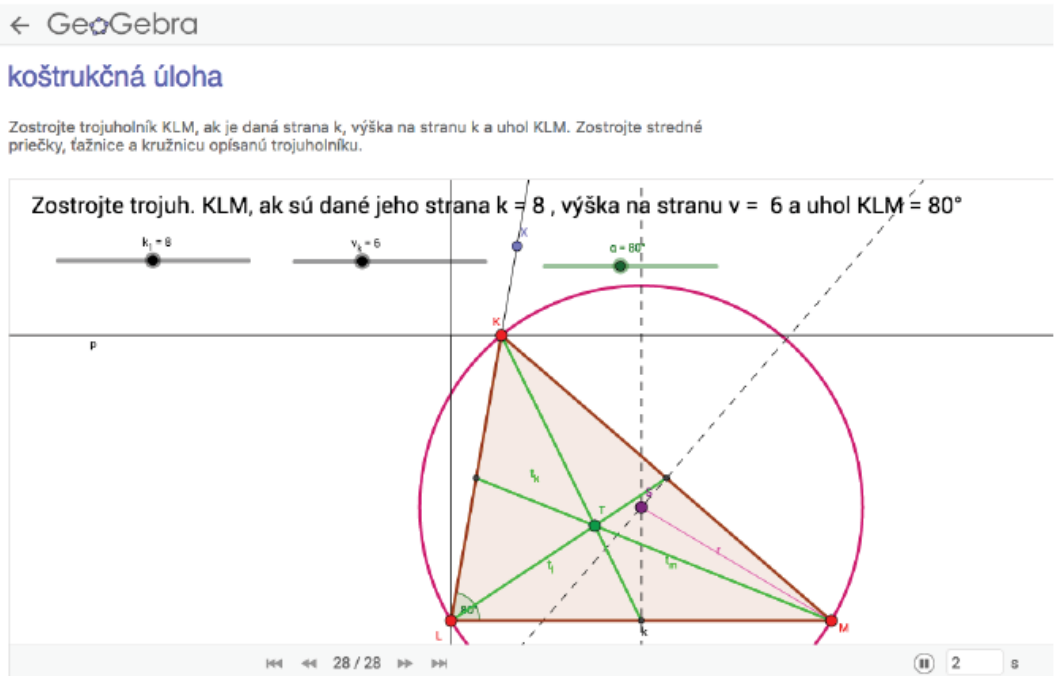

Figure 2. An animated construction problem in Geogebra.

S o u r c e : Koreňová, 2015.

The QR codes may also address links on the portal GeoGebratube. One can benefit from these ready-to-apply applets.

\section{Using a Graphic Calculator as a Student's Individual Display}

The teachers can prepare their own problems by themselves. In this case, they also need a QR code generator - the software encrypting a text (usually an URL address) into its QR code. The CASIO Classwiz calculator includes it in its standard software. First, the teacher prepares the problem by himself or herself to a state in which his or her students' activity should begin. Then, he or she produces its QR code. After its encoding, the data file stores the current status of the Classwiz screen. As CASIO Classwiz is not a graphic calculator, the problem is "frozen" in its numerical format. It can be unfrozen and transferred to a graphic device by anyone who reads it by his or her smartphone or tablet. The file is restored in its memory, and the user can continue its solution from the given moment.

Figure 3 shows a solution of the cubic equation $x^{3}+507 x^{2}+62370 x=0$. Then, the user presses SHIFT+OPTN to read the code. The screen shows the graph (see Figure 3). 
The same approach can be applied for various purposes. As mentioned above, Figure 3 shows a graphic solution of the cubic equation. The solution can continue by determining values of the roots, by finding a local maximum and a local minimum of the function within a specified interval, etc. The partially solved problems can be used during tests and exams. In these situations, the prepared files allow all students to use the same data sets. This is important when a file is extensive e.g. in problems in statistics.

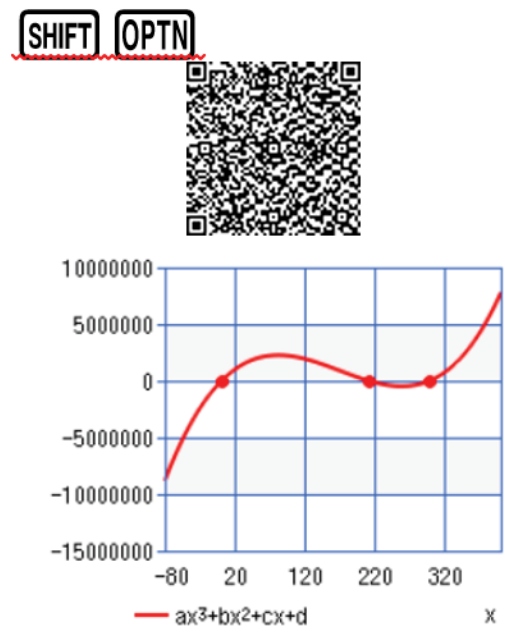

Figure 3. Use of a QR code in Classwiz.

S our c e : Own work.

\section{Sets of QR Codes: Towards Complex Solutions}

As has been indicated above, there are many ways of applying QR codes to facilitate education. All examples were one-purpose. Their only role is to deliver its corresponding content and to evoke an educational activity. At the same time, sets of QR codes can form a complex environment addressing an entire subject. Then, the individual files address a learning unit but their contextual meaning is changing because it builds the course context. We illustrate the idea with the following example - the use of a complex system of self-supporting electronic tools including QR code based access as its part.

The educational process is formed around a textbook (Hvorecký, 2013a). It addresses an introductory database course for students of management. The course is taken by both regular and external students. While the regular students attend lectures and work in laboratories under lecturers' guidance, the external 
students miss these interpersonal contacts. Preparing the textbook came up as the very traditional step to enhance their learning - to write a supplementary text. Then, a question rose: The students need their computer (or at least a regular access to it) to study a database course. Can we find additional computer-based methods to facilitate their study? The implemented solution is complex; access using QR codes is just a part of it.

As a result of these considerations, the textbook contains several hundred problems. In order to make the basic text shorter (it has got almost 300 pages), unsolved problems are collected in a separate booklet (Hvorecký, 2013b). The problem solver itself is about 100 pages long because it contains more than 200 problems of different levels of difficulty.

Database problems require large data sets. Typing them would be timeconsuming. There certainly would appear unintentional errors as a result of manual typing. To avoid the danger, a USB memory key has been attached to the problem solver. It contains databases necessary to all problems.

Počitačové databízy nie sú priamym obrazom nasich tradičných. manuálne spracovávaných databiz. Keby boli talé, nemuseli by sme sa trápit" s návihovym zobrazenim. Mohli by sme zostat' na licnej strane

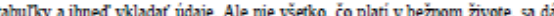
preniest' do počtačových databáz. Nielenže .štyri" nie sú ..4", platia aj dalkíe neobvyklé zásady. Jedina $z$ najdôležitej ǰich zrie:

\begin{tabular}{|c|}
\hline iadne dva riadlky) v tej istej tabul'ke nesmú byf totožmé. \\
\hline 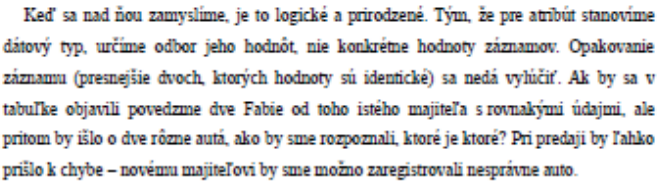 \\
\hline 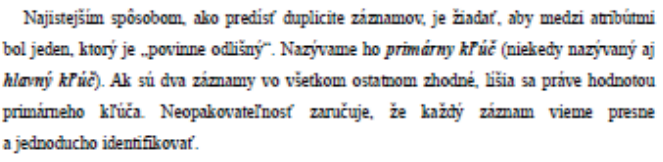 \\
\hline 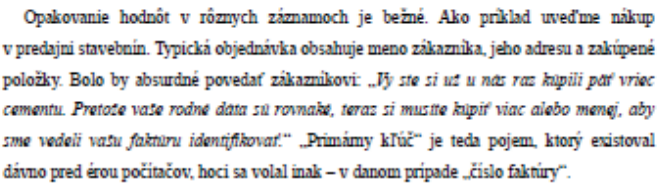 \\
\hline $\begin{array}{r}\text { Hodnoty primárneho kl'úča sa musia lís } \\
\text { opal }\end{array}$ \\
\hline
\end{tabular}

Niektoré skupiny objektov maju prinodzeny primany kluc. Napriklad EVC (evidenćné čislo vozicla) pridelowané policiou garantuje jeho jedinečnost'. Ostamé atribúty sa môžu

Figure 4. A textbook page with a QR code to a video. 
The USB key contains more than just necessary data. The solutions are "partially complete" to the degree that allows the students to concentrate exclusively on their final parts - the study material delivered in the given chapter. For example, when they are asked to build a user-friendly communication, the "raw" database is formally complete but it would require a database specialist to exploit it. As a result, the student can concentrate on building the particular "clearly isolated" task building a user-friendly communication of a completed database. The problems can be solved using analogy with comparable problems presented in the textbook. The chapter numbering in the textbook and in the problem solver are identical, i.e. finding relevant solved problems to unsolved ones is easy.

The database courses are generally accepted as difficult ones. It is based on the fact that working with the database management system (an authoring tool for building databases) is difficult. The solution requires a lot of attention; the probability of unintentional errors is rather high. All detailed steps must be done with caution and tested using large input data sets. The number of these technicalities can overwhelm their readers, and they can easily become lost. To help our students understand the problem at both formal and intuitive levels, new knowledge is also delivered using two formats. The explicit, exact, and detailed description is done in the textbook. Less formal (tacit) knowledge is provided via video lectures. The reference to the particular video is made by a QR code. Its encoded link refers to YouTube (see Figure 5).

In total, thirty videos done by the author were shot and posted on YouTube. In the videos, the author demonstrates slides and speaks about the particular problem in a rather informal style. The videos cover the course sections which - in accordance with the author's experience - represent the most difficult sections of the course. Their duration is four to ten minutes. All videos are stored on YouTube and their corresponding slides at the USB memory key together with the "halfcompleted" databases.

\title{
Vkladanie údajov
}

\author{
Video is on the site: \\ http://www.youtube.com/watch?v=gGOyUZxPtFA
}

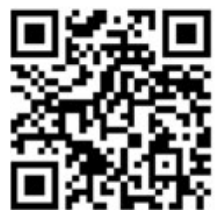

Figure 5. The title slide of PowerPoint file with the QR code and URL address of video lecture.

S o u r c e : Own work. 
The list of course supporting materials is as follows:

- a textbook with thirty QR codes: the code is placed next to the piece of knowledge the lecture explains;

- a problem solver: a booklet with about two hundred problems to be solved using MS Access;

- a USB memory key: a standard device with two file folders - the first one contains databases needed for problems presented in the problem solver, and the second one contains PowerPoint slides used in the videos;

- two hundred MS Access databases (one for each problem): for users' quick orientation, their names are based on the numbering of problems in the problem solver; and

- thirty PowerPoint files with slides: their names are based on the page number in the textbook with the relevant QR code (the first slide contains the same QR code and the URL address at YouTube - see Figure 5).

All this indicates that the set of material can be used for any cohort of novices who are interested in database design and implementation. The methodology was also tested on a group of pre-service students of informatics (Hvorecký, Drlík, \& Munk, 2010). The outcomes were highly positive.

\section{Conclusion}

QR codes offer numerous ways in which the teaching and learning materials can be facilitated. Many positive examples in the previous sections demonstrate it. At the same time, no technology has been - and will ever be - the saviour of education. For that reason, we would like to point to the potential risks of using QR codes.

First, the success in education strongly depends on the personality of the teacher. He or she has to know when to use this technology and when not to. There are moments during the learning process when the support from a knowledgeable person is irreplaceable. As Hvorecký and Koreňová (2018) show, there are ways of reducing them and letting the learner go alone. Again, there has to be a sufficient amount of learning material of good quality.

Then, there can be problems with technology. The work with QR codes presumes the access to the Internet. Without a fast connection, the communication can be limited, with can have negative consequences for the learners' motivation. In addition to that, the quick development of information technology can result in some application's inability to run on the newest devices (due to the updates of hardware, software, operating system, programming languages, and/or other factors). 
It also means that the authors of QR-using applications must pay attention to these innovations, and upgrade their teaching and learning materials, too. As the upgrading process is time-consuming, they should discuss the advantages and drawbacks of technology use, especially when they plan to design and develop their applications for long-time exploitation.

All of it implies that QR codes are excellent tools but - as everything in our contemporary society - keeping them alive requires regular and cautious maintenance.

\section{Acknowledgements}

The paper was written with the support of the grant KEGA 012UK-04/2018 "The Concept of Constructionism and Augmented Reality in the Field of the Natural and Technical Sciences of the Primary Education (CEPENSAR)."

\section{References}

Abas, H., Yahya, F. H., \& Kamaruddin, M. (2015). User readiness evaluation of QR codes in mobile learning (m-learning). In Proceedings from IC-ITS. 2-5 May 2015, Lugano, Switzerland.

Bohumelová, M. \& Hvorecký, J. (2015). Digitized art promotes the cultural heritage. In Proceedings from the $13^{\text {th }}$ International Conference Emerging eLearning Technologies and Applications (ICETA) (pp. 1-5). IEEE, 26-27 November, Starý Smokovec, Slovakia.

Chicioreanu, T. D., Bilal, E., \& Butnariu, M. (2015). QR codes in education - success or failure? In Proceedings from the $11^{\text {th }}$ International Scientific Conference eLearning and Software for Education (pp. 180-187). 23-24 April, Bucharest, Romania

Curtis, M., Luchini, K., Bobrowsky, W., Quintana, C., \& Soloway, E. (2002). Handheld use in K-12: A descriptive account. In Proceedings from Wireless and Mobile Technologies in Education, IEEE International Workshop (pp. 23-30). IEEE. 29-30 August 2002, Växjö, Sweden.

Gunčaga, J. \& Janiga, R. (2016). Virtual labs and educational software as a tool for more effective teaching STEM subjects. In: Proceedings from the Third International Conference on Computer Science, Computer Engineering, and Education Technologies (pp. 1-12). Łódź: Łódź University of Technology.

Hvorecký, J. (2013a). Databázové technológie. Košice: Equilibria.

Hvorecký, J. (2013b). Databázové technológie: Podporný učebný materiál. Košice: Equilibria.

Hvorecký, J., Drlík, M., \& Munk, M. (2010). The effect of visual query languages on the improvement of information retrieval skills. Procedia - Social and Behavioral Sciences, 2(2), 717-723.

Hvorecký, J. \& Koreňová, L. (2018). Learning critical thinking without teacher's presence. DIVAI 2018. 2-4 May, Štúrovo, Slovakia. 
Koreňová, L. (2015). Digitálne technológie vo vyučovani matematiky. Bratislava: Univerzita Komenského.

Lai, H. C., Chang, C. Y., Wen-Shiane, L., Fan, Y. L., \& Wu, Y. T. (2013). The implementation of mobile learning in outdoor education: Application of QR codes. British Journal of Educational Technology, 44(2), E57-E62.

Leone, S. (2015). The QRcode format as a tool for inclusive, personalised, and interdisciplinary learning experiences. In Encyclopedia of Information Science and Technology, $3^{\text {rd }}$ edition (pp. 2626-2635). IGI Global.

Ramsden, A. (2008). The use of QR codes in education: A getting started guide for academics. Bath: University of Bath.

Silberman, M. (1996). Active learning: 101 strategies to teach any subject. Prentice-Hall, PO Box 11071, Des Moines, IA 50336-1071.

Tóthová, R., Kostrub, D., \& Ferková, Š. (2017). Žiak, učitel' a výučba (všeobecná didaktika pre študentov učitel'stva). Prešov: Rokus.

Lilla Koreňová, Jozef Hvorecký

\title{
Stosowanie kodów QR w stymulowaniu edukacji matematycznej i informatycznej
}

\author{
Streszczenie
}

Temat kodów QR porusza się w kontekście uczenia się z wykorzystaniem aplikacji mobilnych. $\mathrm{W}$ artykule przedstawiono inne możliwości wykorzystania tych kodów z podkreśleniem edukacji matematycznej i informatycznej oraz ich metodologii. Kody QR, właściwie umiejscowione, mogą być na przykład użyte w tworzeniu informacji zwrotnej dla zarówno uczniów, jak i nauczycieli, jako dodatkowe źródło zadań problemowych w aplikacjach nauczających rozwiązywania problemów lub kartach zadań, lub też jako bramka informacji w grze dydaktycznej. Uczniowie używają smartfonów, by przeczytać wybrany kod QR. Kod odnosi się do katalogu zawierającego pliki z danymi wcześniej przygotowanymi oraz zapisanymi przez nauczyciela lub twórcę materiałów dydaktycznych. Dane te są następnie wykorzystywane zgodnie z instrukcją nauczyciela. Kod QR może również służyć do powiązania źródeł dodatkowej informacji na karcie pracy lub otworzyć uczniowi bramkę umożliwiającą ewaluację kursu lub wydanie oceny przez instruktora. W artykule przedstawiono przykład takiego podejścia z różnych obszarów matematyki, statystyki oraz baz danych. Na zakończenie omówiono zalety i wady takiego podejścia.

Słow a kluczowe: kod QR, informatyka, uczenie się z wykorzystaniem aplikacji mobilnych, uczenie się na odległość 
Lilla Koreňová, Jozef Hvorecký

\title{
Применение QR-кодов в обучении математике и информатике
}

\section{А н но т а ц я}

\begin{abstract}
QR-коды обычно обсуждаются в контексте мобильного обучения. В нашей презентации мы показываем другие возможности их использования с акцентом на образовании в области математики и информатики и его методологии. Надлежащим образом размещенные QR-коды могут, например, использоваться для создания обратной связи, как для учащихся, так и для преподавателей, в качестве дополнительного источника проблем для решения на листе или в качестве начала дидактической игры. Адресаты используют свои смартфоны, чтобы прочитать выбранный QR-код. Код относится к файлу, содержащему данные, предварительно разработанные и сохраненные преподавателем или автором учебных материалов. Затем данные используются в соответствии с инструкцией преподавателя. Аналогичным образом, QR-код может связывать дополнительные источники информации на рабочем листе или открывать доступ студента к оценке курса / преподавателя. В статье мы иллюстрируем такой подход, используя примеры из различных областей математики, статистики и баз данных. В заключении мы обсуждаем преимущества и недостатки данного подхода.
\end{abstract}

К л ю ч е в ы е с л о в а: QR-код, Образовательные технологии, Мобильное обучение, Дистанционное обучение

Lilla Koreňová, Jozef Hvorecký

\section{Aplicación de códigos QR en la adquisición de la Educación Matemática e Informática}

Resumen

El debate de los códigos QR suele tener lugar generalmente en el contexto del aprendizaje móvil. En nuestro trabajo, mostramos otras oportunidades de su explotación poniendo el acento en la Educación Matemática e Informática y su metodología. Los códigos QR empleados apropiadamente pueden, por ejemplo, ser explotados para crear una retroalimentación tanto para estudiantes como para docentes, como una fuente adicional para la resolución de problemas o una hoja de trabajo o como una puerta de entrada a un juego didáctico. Las personas destinatarias usan sus teléfonos inteligentes para leer el código QR seleccionado. El código se refiere a un archivo que contiene los archivos de datos prediseñados y almacenados por su profesorado o el autor o autora de los materiales de aprendizaje. Los datos se explotan de acuerdo con las instrucciones del docente. De manera similar, un código QR puede vincular fuentes de información adicionales en una hoja de trabajo o para abrir la puerta del estudiante a la evaluación del curso / instructor. En el documento, ejemplificamos este enfoque utilizando ejemplos de diversos campos de Matemáticas, Estadísticas y Bases de datos. Finalmente, se discuten las ventajas y desventajas de este enfoque.

Palabras c lave: código QR, tecnología educativa, aprendizaje móvil, educación a distancia 


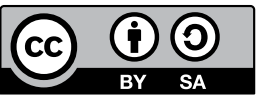

DOI 10.31261/IJREL.2018.4.2.04

\author{
Nadiia Balyk \\ Ukraine (ORCID: 0000-0002-3121-7005)
}

\title{
Galina Shmyger
}

Ukraine (ORCID: 0000-0003-1578-0700)

\section{Yaroslav Vasylenko}

Ukraine (ORCID: 0000-0002-2954-9692)

\section{Influence of University Innovative Educational Environment on the Development of Digital STEM Competences}

\begin{abstract}
The article deals with the problem of the influence of the innovative educational environment of the university on the development of digital STEM competences in the process of training teachers of the new formation. It is determined that the innovative educational environment of the university consists of organisational, educational, methodological, and technological and information resources, the purpose of which is to create conditions for the development of digital STEM competences of teachers. The main aspects of introduction and development of STEM education in different countries of the world are analysed. Particular attention is paid to the functioning of the STEM Centre, which is the basis of the innovative educational environment of the pedagogical university. The practical experience in introduction of STEM education at Ternopil Volodymyr Hnatiuk National Pedagogical University is summarised. The peculiarities of the influence of the innovative educational environment of the university on the development of digital STEM competences are explored.
\end{abstract}

K e y w o r d s: STEM education, digital STEM competences, innovative educational environment, project-based learning, research 


\section{Introduction}

Many countries in the world, including developed economies such as those of the United States and the European Union (EU), transform their education systems in order to be competitive in the age of innovation (Schleigh, Bossé, \& Lee, 2011; Williams, 2011). Innovation is largely dependent on advances in science, technology, engineering, and mathematics. More and more jobs in all sectors of the economy require STEM knowledge, which goes beyond training for specific jobs. STEM education is aimed at developing deep mathematical and scientific knowledge, as well as developing a way of thinking and reasoning. STEM education promotes the development of creative skills and critical thinking that young people can use in all areas of their lives (Morze, Smyrnova-Trybulska, Kommers, Gladun, \& Zuziak, 2017).

Ukrainian students should also be competitive on the labour market of the $21^{\text {st }}$ century. Reforms taking place in the sphere of education of Ukraine contribute to this. The implementation and development of STEM education is especially important today. Within the framework of STEM education, interdisciplinary curricula are introduced, students' knowledge of STEM subjects and STEM professions increases, STEM courses are provided for students, and students are trained for successful post-school employment and education. At the same time, at each stage, this system develops students' ability to do research, work analytically, experiment, and think critically; it combines school and out-of-school opportunities and teaching methods (LaForce, Noble, King, Century, Blackwell, Holt, Ibrahim, \& Loo, 2016).

The analysis of pedagogical literature shows the interest of scientists in various aspects of STEM education. Taking into account that STEM education is one of the most important directions of reforming Ukrainian education, it is worth highlighting some aspects of its implementation in the educational process.

\section{Integrative STEM Education}

In the scientific literature, researchers (Sar1er, 2010; Schleigh, Bossé, \& Lee, 2011) distinguish five aspects of STEM education.

1. STEM education is focusing on challenges and problems. At STEM lessons, students are faced with real social, economic, and environmental issues and seek solutions.

2. STEM lessons focus on the engineering design process. STEM education provides a flexible design process. In this process, students determine the 
problem, conduct preliminary research, put forward a few ideas for their solutions, develop and create a prototype, and then test it, evaluate it, and implement it. STEM lessons provide student teams with opportunities to conduct their research based on their own ideas, test different approaches, make mistakes, discuss them and learn from them, and carry out further research. Their focus is on finding solutions.

3. STEM education immerses students in a practical inquiry and open study. The students' work is practical and collective, and their decisions are coordinated. Students communicate, exchange ideas, and, if necessary, upgrade their prototypes. They control their own ideas and conduct their own research.

4. STEM education involves students in productive collaborative work. They need help from teachers to work together as a productive team. This becomes possible if all the teachers at school work together and meet students' expectations.

5. STEM education integrates math and science. It is necessary to create plans for joint work of teachers of various subjects. Using knowledge from various subjects during lessons will teach students to understand that combining mathematics and other sciences can solve important life problems. This will increase interest in mathematics and science. The art teacher should be drawn to such lessons as well, since art plays an important role in the development of a practice-oriented project, enhancing its attractiveness, design, and demand. In order to integrate mathematics and science, M. Sencer Corlu, Robert M. Capraro, and Mary M. Capraro (2014) suggested the STEM education model. According to it, for the successful transition from the traditional to the integrated model of education, emphasis is placed on the importance of integrated study of disciplines and on the interaction between teachers and students. This model involves a systematic approach to the study of natural and mathematical disciplines, and promotes the development of innovation, the implementation of creative potential of the individual, and its pre-professional education.

A prominent place in this model belongs to a well-educated and experienced teacher with strong skills to interact with other subject teachers, students, and parents. Such a teacher must understand the importance of integrated pedagogical education programmes, and have expert knowledge from the main subject area and working knowledge in other areas (Corlu, R. Capraro, \& M. Capraro, 2014; Williams, 2011).

Implementation of STEM disciplines is required depending on the level of development of the innovative educational environment of the educational institution. Under the innovative educational environment of the university, we will understand organisational, educational, methodological, technological, and informational resources, the purpose of which is to create conditions for the development of digital STEM competences of teachers. 
The purpose of this article is to consider the problem of the influence of the innovative educational environment of the university on the development of digital STEM competences in the process of training teachers of the new formation.

\section{Implementation of STEM Education at Ternopil Volodymyr Hnatiuk National Pedagogical University}

The policy of coordination between school and university will improve the quality of pedagogical education at the initial stages of the implementation of STEM education. Such coordination activity can be carried out in two directions: programmes for training of future teachers and teachers' qualification upgrading. Teacher training programmes developed in tandem with school curricula will facilitate the teachers' acquisition of the necessary knowledge and experience in the educational environment of a modern school where the principles of STEM education are implemented (Sanders, 2009).

The implementation of the principles of STEM education at Ternopil Volodymyr Hnatiuk National Pedagogical University succeeded in providing:

- integration of the best STEM educational practices of domestic and foreign experience;

- development of new teaching materials (interdisciplinary programmes) in educational institutions; and

- encouragement of students of the pedagogical university to study STEM subjects.

The STEM Centre, which is the basis of the University's innovative educational environment, has been operating in Ternopil Volodymyr Hnatiuk National Pedagogical University - at the Faculty of Physics and Mathematics - for three years. The scientific and technical activity of STEM Centre is carried out with the participation of scientific and pedagogical staff of the Department of Computer Science and Teaching Techniques. Teachers of the Department provide educational services in the field of STEM to students and teachers.

The aim of the STEM Centre as an innovative educational environment of the University is to create organisational and pedagogical conditions for advanced scientific and technical youth education in accordance with the priority directions for science and technology development, and to form the competences that determine the competitiveness of the individual in the labour market. The profile of the educational activities of the STEM Centre of the University determines the following areas of STEM education: IT, robotics, virtual reality, Internet of things, $3 \mathrm{D}$ modelling, and 3D printing. 
This profile is provided by the availability of the appropriate equipment: LEGO construction toys, robotic systems, models, measuring complexes and sensors, 3D printers, computers, digital projectors, projection screens, interactive whiteboards, document cameras, etc. High-tech equipment helps students in designing and researching, modelling various processes and phenomena, and mastering new transdisciplinary knowledge consciously and qualitatively.

The activities of the STEM Centre are based on pilot-oriented project-based learning aimed at in-depth study of specialised disciplines and the acquisition of digital STEM competences required for experimental, design, and inventive activities.

The STEM Centre activity forms STEM competence of students, and they acquire knowledge in many disciplines and learn skills in using interdisciplinary approaches to solve real-life problems (Balyk, Barna, Shmyger, \& Oleksiuk, 2018).

The transition to the competence model of STEM education at Ternopil Volodymyr Hnatiuk National Pedagogical University is based on the application of the following methodological approaches:

- shifting in emphasis in educational activities from narrow-subject to common didactics;

- setting a new goal in the pedagogical process;

- updating the structure and content of curricula, courses, and specialised courses;

- introducing competence-oriented forms and teaching methods;

- assessing learning outcomes in terms of competences;

- introducing innovative teaching technologies (case-study technologies, interactive methods of group training, problem-oriented techniques for developing critical and system thinking, etc.); and

- creating pedagogical conditions for gaining experience of project activity and start-ups development.

The STEM Centre provides education based on the principles of differentiated and individual approaches to learning, taking into account age, individual abilities, interests, likes, abilities, and health status of children and young people, using different organisational forms of work.

A special form of pervasive STEM education are integrated lessons aimed at establishing inter-subject relationships and contributing to the formation of a holistic, systematic outlook. Integrated classes are conducted by combining similar topics of several educational subjects or forming individual ones. The basis of the effectiveness of such classes is a clear definition of their purpose and plan.

The use of the leading principle of STEM education, that is, integration (interdisciplinary, transdisciplinary) makes it possible to modernise methodological foundations, content, and volume of educational material and to apply modern technologies during education process in order to form competences on a qualitatively new level. 
In order to involve students in practical activities at the STEM Centre, organisational forms and teaching methods, as well as methods of educational interaction were expanded. For better acquisition of learning material and formation of digital STEM competences, we conduct tours, quests, contests, festivals, hackathons, trainings, and seminars.

In addition to traditional intellectual events (contests, tournaments), the STEM Centre plans to conduct scientific-educational events, STEM weeks, scientific picnics, festivals on robotics, and maker fairs. The STEM Centre also organises and holds events for vocational guidance (trainings, excursions) of students concerning a conscious choice of future profession, taking into account the regional characteristics of the labour market. Examples are: STEM-creaton regional festival, STEM-spring all-Ukrainian festival, Day of Science, Visiting TNPU, Class Idea festival of startups, the all-Ukrainian festival of innovations, winter and summer STEM-schools.

An effective tool for the development of digital STEM competences is a project activity that changes the emphasis of learning activities. The acquisition of knowledge, skills, and abilities that - in the global information environment - are losing their relevance cannot be a goal in itself, while the research skills and practical experience gained in the process of project activity will promote acceleration of adaptation of young people to a changing social and economic life.

Implementation of educational projects involves an integrated research and creative activity of students, aimed at obtaining independent results under the teacher guidance. In the process of studying various courses and specialised courses, students develop training projects based on the system of integrated tasks simulated from real life situations.

The teacher manages such activities, encourages students to search; he helps in determining the goals and objectives of the project, advisory methods or techniques of the research, and in information seeking to solve certain educational and cognitive tasks. Students themselves choose the form of presentation and defend the received results. Evaluation of the project activity is carried out individually.

During the execution of educational projects, a number of different levels of didactic, educational, and developmental tasks are solved: new knowledge, abilities, and skills are acquired; motivation and cognitive interests are developed; the abilities to independently navigate the information space, express one's own judgments, and identify competence are formed. The design work contributes to the formation of STEM competences (Shmyger \& Balyk, 2017), and allows passing the technological algorithm from the problem's discovery, or the origin of the idea, to the creation of a commercial product - a startup, as well as learning to present it to potential investors. Ultimately, this will contribute to changing the value priorities and ideological position of youth in the direction of the formation of responsible and socially active social behaviour. 
In the educational process, the teachers of the Department of Computer Science and Teaching Techniques of Ternopil Volodymyr Hnatiuk National Pedagogical University test different types of projects: project-task, project-discipline, and project-start-up. Here are some examples of the projects:

- study with pleasure,

- STEM projects,

- technologies of a successful personality development,

- make the city better,

- development of the project and social management system,

- development of media resources for the creation of an open co-learning centre for the promotion of the ideas of the Ukrainian Charter of the Free Person,

- development of innovative educational projects based on the concept of the New Ukrainian School, and

- innovative approaches to the use of ICT and competence education in the conditions of the New Ukrainian School.

Let us place greater focus on the implementation of the educational project "Development of innovative educational projects based on the principles of the New Ukrainian school," which started in 2017. As a result of it, more than two hundred portfolios of integrated educational projects were developed and performed by undergraduates of all specialties of the University for primary and secondary school teachers.

The current vector of the innovative educational environment of the University is the organisation of the educational process as an integral part of the entire educational process and orientation, primarily, on universal human values. One of such innovative projects in the social sphere, which implements the innovative function of the University for the creation of new social and humanitarian practices, was the project to popularise the ideas of the Ukrainian Charter of the Free Person.

Future teachers created methodological support with media to promote ten Charter novels and their practical use with education and training aim in educational institutions, as well as for public community activities in Ukraine.

\section{Research Results}

In our opinion, the key to the development of digital STEM competences was the impact of the University's innovative educational environment and the activities of the STEM Centre. In 2017/2018, a poll was conducted to determine the factors of the University's innovative educational environment that have the greatest impact on the development of digital STEM competences for preservice teachers. 
The survey involved 138 students of the third year of the Faculty of Physics and Mathematics and the Faculty of Chemistry and Biology. The questionnaire offered to evaluate the components of the innovative educational environment of the university on a 5-point scale and to determine the importance of the development of each component on a 3-point scale: 1 - low, 2 - medium, and 3 - high.

Let us consider the results of the survey conducted concerning the importance of developing the hardware, organisational, methodological, and software components of the university's innovative educational environment for the development of digital STEM competences of students at Ternopil Volodymyr Hnatiuk National Pedagogical University (Figures 1-4).

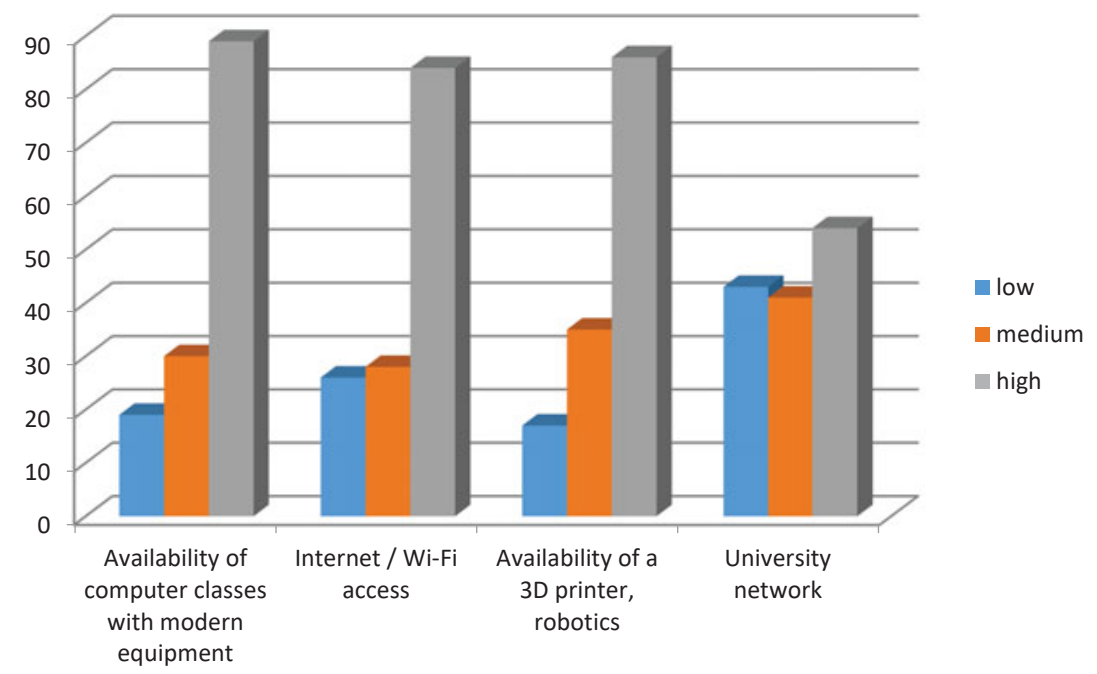

Figure 1. Results of the study of the importance of the hardware component of the university's innovative educational environment in the context of the development of digital STEM competences.

S ource : Own work.

Concerning the hardware component, such indicators as availability of a 3D printer, robotics, and other equipment of the STEM Centre (65\%), modern computer classes (61\%), high-speed Internet (62\%), and developed university computer network $(39 \%)$ are the most significant (the importance of the component on a 3-point scale is high) for development of the digital STEM competences of students. A small percentage of university network component can be explained by the fact that there is a sufficient number of students possessing gadgets with Internet access.

In recent years, the University has been actively introducing non-formal education (training sessions, workshops, seminars, webinars, round tables, conferences, contests, internships). Therefore, $63 \%$ of students (the importance of development of a component on a 3-point scale is high) noted it as a factor that 
greatly influenced the development of their digital STEM competences. It can be summarised that in the framework of the innovative educational environment of the university, formal and non-formal education of future teachers complement each other, compensating for disadvantages of these types of education.

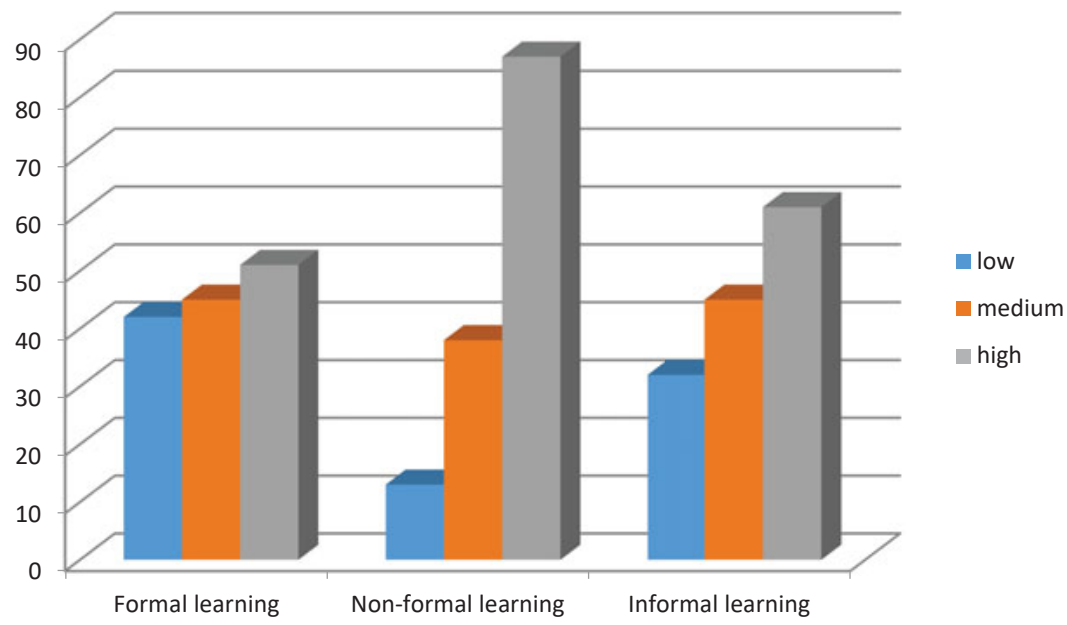

Figure 2. Results of the study of the importance of the organisational component of the university's innovative educational environment in the context of the development of digital STEM competences.

S o u r c e : Own work.

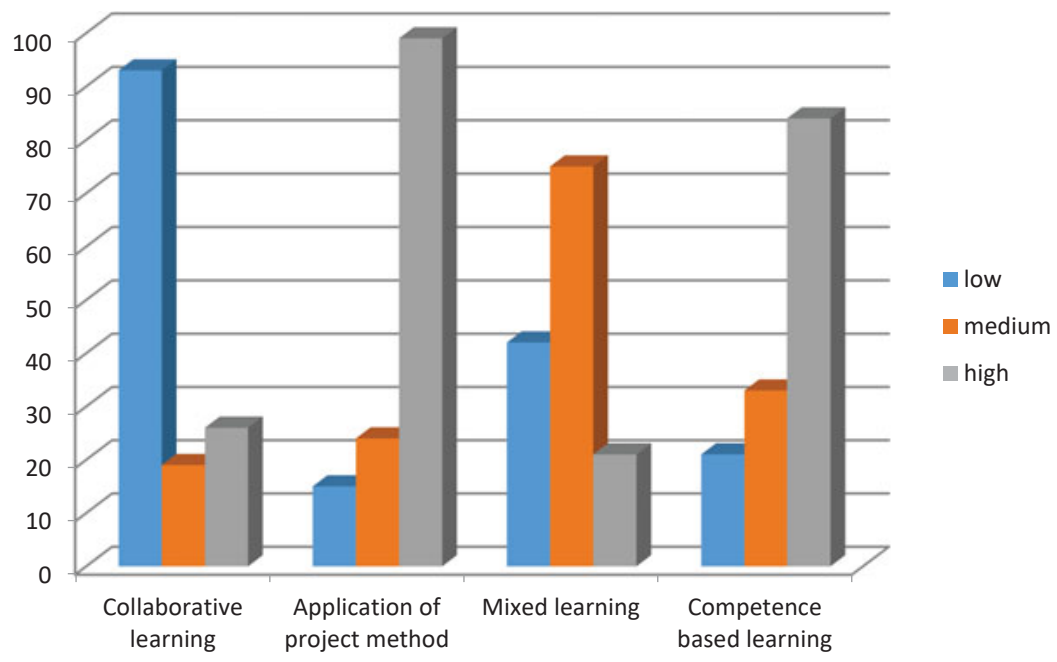

Figure 3. Results of the study of the importance of the methodical component of the university's innovative educational environment in the context of the development of digital STEM competences.

S o u r c e : Own work. 
Among the teaching methods, students of Ternopil Volodymyr Hnatiuk National Pedagogical University have allocated project-based learning (72\%) and competence-based learning $(61 \%)$ as important ones (the importance of development of the component on a 3-point scale is high). Despite the high rates of project-based learning and competence-based learning, students (67\%) still do not accept collaborative learning (the importance of development of the component on a 3-point scale is low).

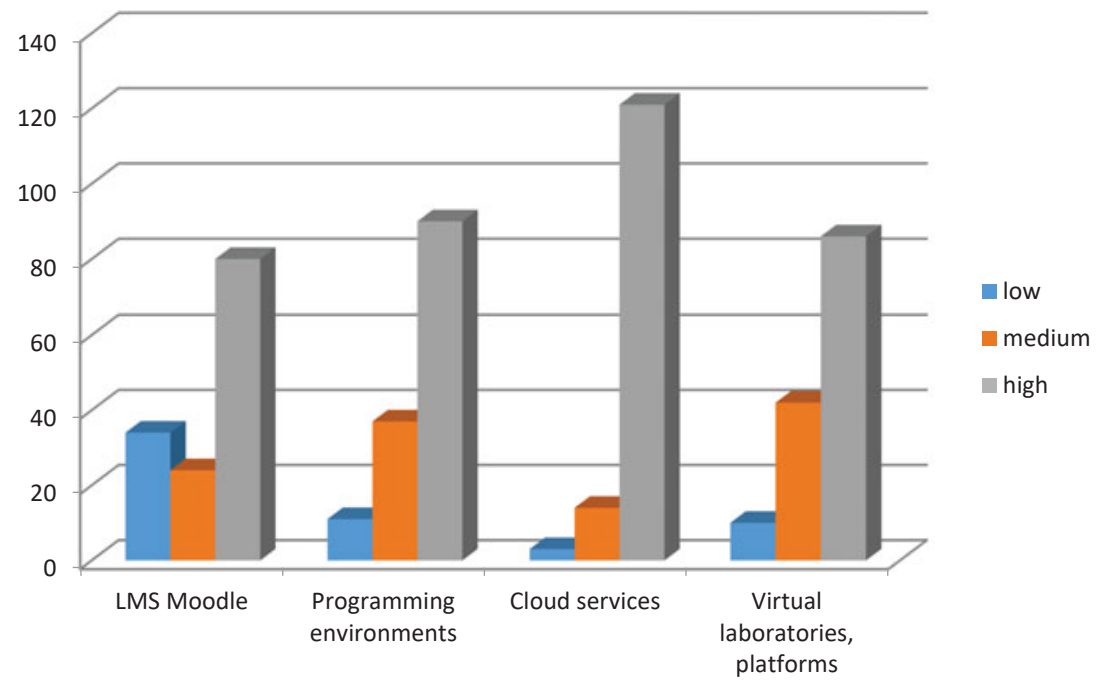

Figure 4. Results of the study of the importance of the programming component of the university's innovative educational environment in the context of the development of digital STEM competences.

S our c e : Own work.

Cloud computing (87\%), programming environments $(65 \%)$, virtual laboratories and platforms $(62 \%)$ proved to be the most important concerning the software component of the programme (the importance of development of the component on a 3-point scale is high) for the development of digital STEM competences of students.

Modernisation of the software component enabled combining traditional and cloud-based learning tools, integrating cloud services (Google, Microsoft) into the IT infrastructure of the University, and organising training courses based on cloud platforms and cloud services.

In the learning process, we use cloud services for the development of creativity (Table 1), leadership and responsibility (Table 2), and problem solving (Table 3), but also for strengthening collaboration and team work (Table 4), and the development of effective communication (Table 5). 


\section{Digital Tools for STEM Competences Development}

Table 1.

Digital tools for development of creativity

\begin{tabular}{ll}
\hline & \multicolumn{1}{c}{ Creativity - an innovative mindset } \\
\hline Easely & creating posters and infographics \\
Prezi & online presentation tool \\
Dumpr & creating photo collages by templates \\
BannerSnack & creating banners \\
EnjoyPic & creating combined images with photos and applying \\
Photosynth & creating three-dimensional modelling of photo panoramas \\
\hline
\end{tabular}

S our c e: Own work.

Table 2.

Digital tools for development of leadership and responsibility

\begin{tabular}{ll}
\hline \multicolumn{1}{c}{ Leadership and responsibility - initiative and awareness of personal responsibility } \\
\hline Google Apps & $\begin{array}{l}\text { organising collective work by creating a joint document or } \\
\text { presentation } \\
\text { moderating a thematic group in a social network, } \\
\text { Facebook }\end{array}$ \\
Trello & $\begin{array}{l}\text { effective management of own tasks and tasks of members of } \\
\text { a team (group, project) } \\
\text { keeping an online diary, covering the news and own vision, } \\
\text { Blog }\end{array}$ \\
\hline
\end{tabular}

S o u r c e: Own work.

Table 3.

Digital tools to develop problem solving

\begin{tabular}{ll}
\hline \multicolumn{2}{c}{ Problem solving - will, awareness of the causes and consequences } \\
\hline Bubells, Mind42 & $\begin{array}{l}\text { creating a map of knowledge with all possible options for } \\
\text { solving the problem, thinking out the possible results of each } \\
\text { solution } \\
\text { writing down problems and tasks, adding decision ideas, and } \\
\text { noting solved problems and tasks }\end{array}$ \\
FoneNote & $\begin{array}{l}\text { organising forums for communication and discussion } \\
\text { WebTalk, Skype }\end{array}$ \\
\hline
\end{tabular}

S o u r c e: Own work. 
Table 4.

Digital tools for enhancing cooperation and teamwork

Cooperation and teamwork - abilities to plan activities collectively, work together, distribute roles and responsibilities, and focus on results

\begin{tabular}{ll}
\hline Google Docs & $\begin{array}{l}\text { creating and editing documents, spreadsheets, or } \\
\text { presentations together; commenting and discussing created } \\
\text { materials }\end{array}$ \\
saving documents, programmes, music, videos, photos in \\
a shared repository; giving access to files to other users \\
sharing reviews or suggestions on a shared board; printing \\
text, drawing, embedding files, using full board for further work \\
Padlet & $\begin{array}{l}\text { organising work with groups } \\
\text { creating an informational virtual board (images, stickers, text) }\end{array}$ \\
Doogle groups & $\begin{array}{l}\text { creating a joint on-line organiser with a schedule of } \\
\text { events, promptly updating information, conducting group } \\
\text { correspondence on a certain topic }\end{array}$ \\
\hline
\end{tabular}

S o u r c e: Own work.

Table 5.

Digital tools for the development of effective communication

Effective communication - expressing and arguing opinion, possessing rhetorical skills, achieving communicative goals

Skype, Viber communicating and solving problems with people anywhere, regardless of their location; teaching and learning through online communication

Buzzumi, Speakplace organising video communication, conferences, webinars, video interviews; creating and organising audio conferences creating questionnaires and conducting online surveys to

Google Forms determine the needs or personal opinions of people; analysing the results of the surveys in the charts

Gmail, Outlook communicating competently by e-mail, taking into account the ethics of communication; organising the contacts of people

S o u r c e: Own work.

Using the abovementioned cloud services made it possible for students to aggregate computing resources, increase the flexibility of their use, and create scalable repositories based on cloud computing. 


\section{Conclusions}

The basis of the innovative educational environment at Ternopil Volodymyr Hnatiuk National Pedagogical University is the modern STEM Centre. Transition to STEM education competence model in Ternopil Volodymyr Hnatiuk National Pedagogical University is based primarily on creating conditions for teachers to gain experience of project activities.

The study revealed the factors that most contributed to the development of digital STEM competences in the pedagogical university: the availability of hightech equipment STEM Centre; modern computer labs and high-speed Internet; advanced university computer network; virtual laboratories and platforms; programming environments and various cloud services; project-based learning and competence-based learning.

The results of the survey will enhance the effectiveness of the learning process and further development of teachers' digital STEM competences.

The prospect for further research is to develop educational strategies for the implementation of STEM education in the process of teachers' qualifications upgrading.

\section{References}

Balyk, N., Barna, O., Shmyger, G., \& Oleksiuk, V. (2018). Proceedings from the ICTERI 2018 - ICT in Education, Research and Industrial Applications. Integration, Harmonization and Knowledge Transfer. Accessed 27 July 2018. Retrieved from http://ceur-ws.org/Vol-2104/paper_157.pdf.

Corlu, M., Capraro, R., \& Capraro, M. (2014). Introducing STEM education: Implications for educating our teachers for in the age of innovation. Education and Science, 39(171), 74-85.

LaForce, M., Noble, E., King, H., Century, J., Blackwell, C., Holt, S., Ibrahim, A., \& Loo, S. (2016). The eight essential elements of inclusive STEM high schools. International Journal of STEM Education, 3(1), 1-11.

Morze, N., Smyrnova-Trybulska, E., Kommers, P., Gladun, M., \& Zuziak, W. (2017). Robotics in primary school in the opinion of prospective and in-service teachers. A comparison study. International Journal of Continuing Engineering Education and Life-long Learning, 27(4), 318-338.

Sanders, M. (2009). STEM, STEM Education, STEMmania. Technology Teacher, 68(4), 20-26.

Sarier, Y. (2010). An evaluation of equal opportunities in education in the light of high school entrance exams (OKS-SBS) and PISA results. Ahi Evran Üniversitesi Eğitim Fakültesi Dergisi, 11(3), $107-129$.

Schleigh, S., Bossé, M., \& Lee, T. (2011). Redefining curriculum integration and professional development: In-service teachers as agents of change. Current Issues in Education, 14(3), 1-14. 
Shmyger, G. \& Balyk, N. (2017). Formation of digital competencies in the process of changing educational paradigm from e-learning to smart-learning at pedagogical university. In E. Smyrnova-Trybulska (Ed.), Effective development of teachers' skills in the area of ICT and e-learning, Monograph, Vol. 9 (pp. 483-497). Katowice-Cieszyn: University of Silesia Press.

Williams, J. (2011). STEM education: Proceed with caution. Design and Technology Education, $1(16), 26-35$.

Nadiia Balyk, Galina Shmyger, Yaroslav Vasylenko

\title{
Wpływ uniwersyteckiego innowacyjnego środowiska edukacyjnego na rozwój cyfrowych kompetencji STEM
}

\author{
Streszczenie
}

Artykuł dotyczy kwestii wpływu uniwersyteckiego innowacyjnego środowiska edukacyjnego na rozwijanie cyfrowych kompetencji STEM (kompetencji cyfrowych z zakresu nauki, technologii, inżynierii i matematyki) w procesie szkolenia nowego pokolenia nauczycieli. Określono, że innowacyjne środowisko edukacyjne uniwersytetu składa się z zasobów organizacyjnych, edukacyjnych, metodologicznych, technologicznych i informacyjnych. Celem takiego środowiska jest rozwój cyfrowych kompetencji STEM u nauczycieli. Zanalizowano główne aspekty wprowadzenia i rozwoju kompetencji STEM w edukacji w różnych krajach świata. Zwrócono szczególną uwagę na funkcjonowanie centrum STEM, które jest podstawą innowacyjnego środowiska edukacyjnego uniwersytetu pedagogicznego. Dokonano podsumowania praktycznego doświadczenia we wprowadzaniu edukacji o profilu naukowym, technicznym, inżynieryjnym i matematycznym (STEM) na Narodowym Uniwersytecie Pedagogicznym im. Wołodymyra Hnatiuka w Tarnopolu na Ukrainie. Zbadano szczególne aspekty wpływu innowacyjnego środowiska edukacyjnego Uniwersytetu na rozwój cyfrowych kompetencji STEM.

S łow a kluc z ow e: edukacja STEM, cyfrowe kompetencje STEM, innowacyjne środowisko edukacyjne, uczenie się metodą projektów, badania

Nadiia Balyk, Galina Shmyger, Yaroslav Vasylenko

\section{Влияние инновационной образовательной среды университета на развитие STEM компетенций в области цифровых технологий}

А н н о т а ция

В статье рассматривается проблема влияния инновационной образовательной среды университета на развитие цифровых компетенций STEM в процессе подготовки преподавателей для нового образования. Определено, что инновационная образовательная среда университета состоит из организационных, образовательных, методических, технологических и информационных ресурсов, целью которых является создание условий для развития цифровых STEM компетенций преподавателей. Анализируются основные аспекты внедрения и развития обучения STEM в разных странах мира. Особое внимание уделяется функционированию центра 
STEM, который является основой инновационной образовательной среды педагогического университета. Обобщен практический опыт внедрения STEM-образования в Тернопольском национальном педагогическом университете имени В. Н. Гнатюка. Рассмотрены особенности влияния инновационной образовательной среды университета на развитие цифровых компетенций STEM.

К л ю ч е в ы е с л о в а: STEM образование, цифровые STEM компетенции, инновационная образовательная среда, проектное обучение, исследования

Nadiia Balyk, Galina Shmyger, Yaroslav Vasylenko

\title{
Influencia de entornos educativos universitarios innovadores en el desarrollo de competencias digitales innovadoras
}

\author{
Resumen
}

El artículo aborda la influencia de entornos educativos universitarios innovadores en el desarrollo de competencias digitales STEM en la formación del profesorado. Se determina que un entorno educativo innovador en la universidad consiste en recursos organizativos, educativos, metodológicos, tecnológicos e informativos, cuyo objetivo es crear un contexto apropiado para el desarrollo de las competencias digitales de los docentes. Se analizan los principales aspectos de la implementación y el desarrollo de la educación STEM en diferentes países del mundo. Se presta especial atención al funcionamiento del centro STEM, que es la base del entorno educativo innovador de la universidad pedagógica. Además, se resume la experiencia llevada a cabo en Volodymyr Hnatiuk Ternopil National Pedagogical University con competencias STEM. Se exploran las peculiaridades de la influencia del entorno educativo innovador de la universidad en el desarrollo de las competencias STEM.

P a labra s c lave: educación STEM, competencias digitales STEM, entorno educativo innovador, aprendizaje basado en proyectos, investigación 



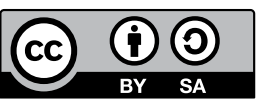

DOI 10.31261/IJREL.2018.4.2.05

\title{
Nadia Saleem
}

Pakistan (ORCID: 0000-0002-6990-7474)

\author{
Aisha M Din \\ Pakistan (ORCID: 0000-0001-6266-5444)
}

\section{Saba Sadiq}

Pakistan (ORCID: 0000-0001-8130-7626)

\section{Masroor Ahmed}

Pakistan (ORCID: 0000-0002-1702-0337)

\section{MDB as an Effective Platform of Communication between Students and Teachers A Study of the Virtual University of Pakistan}

\begin{abstract}
The integration of distance learning and Information Communication technology has brought a lot of convenience for the students who were earlier facing problems in education due to time and geographical limitations. Since the concept of e-learning is comparatively new and different, the discourse on teaching methodologies and the student-teacher relationship in an e-learning environment has brought many new dimensions under discussion. In a virtual system, the communication bonding between a student and a teacher is not so strong. Students are dependent on one-way communication in the form of recorded lectures, published announcements, and information given on a website. Bridging the communication gap between a student and a teacher through MDB (Moderate Discussion Board) is an effective step taken by the Virtual University of Pakistan in online education to address students. The presented research was aimed at investigating the effectiveness of MDB as an interaction platform between students and course instructors at the Virtual University of Pakistan. The effectiveness of MDBs was measured through analysing the number of MDBs posted in a certain
\end{abstract}


course and the nature of questions asked in MDBs by students. It was a quantitative study in which two Mass Communication subjects were selected through purposive sampling. The collected data were analysed in percentages, and a statistical test Correlation was applied to find out if there was some relation between the strength of students and questions asked through MDB. The study found that although the number of MDBs is quite lower than that of enrolled students, it is an effective platform of communication between students and a teacher, as students can ask questions related to subject, exams, semester activities, and general concerns.

K e y w o r d s: e-learning, MDB, communication gap, virtual system

\section{Distance Learning and ICT}

The integration of distance learning and Information Communication technology has brought a lot of convenience for the students who were earlier facing problems in education due to time and geographical limitations. It has indeed provided a great ease and flexibility to the aspiring students residing in far flung areas (Chang, 2002).

Since the concept of e-learning is comparatively new and different, the discourse on teaching methodologies and the student-teacher relationship in an e-learning environment has brought many new dimensions under discussion. Although in an online education system students have some opportunities to communicate with their teachers, these opportunities for communication and interaction are very limited and restricted in comparison to conventional teaching. Educationists and academics believe that interpersonal interaction between students and teachers is one of the key elements in any educational environment. Desmond Keegan believes that since students and teachers are communicating at a distance, the vital link of communication is lost, and thus that link must be restored through overt institutional efforts so that the teaching-learning transaction may be "reintegrated" (Keegan, 1996).

The major source of interaction between a student and a teacher in an e-learning environment is e-mail. It is pertinent to mention here that a teacher in an e-learning institute can provide assistance to only those who have the knowledge thirst in them. Teaching techniques have been shifted to a student-centred approach, where a teacher is there to facilitate a student along with delivering formal education, and success can only be achieved with the collaborative effort of both a student and a teacher. Thus, the students' ability and intent to understand course content and ask questions accordingly appear to be a crucial variable (TerzI \& Çelík, 2005). 
In an online education system, automated grading is always preferred due to convenience, so it is normally restricted to multiple choice questions. This is easy for both students and teachers. Similarly, the result is announced and shared with students immediately after the quiz or exam. However, these multiple choice questions lack in qualitative feedback of the teacher (Tu \& McIsaac, 2002). Critics say that online education is good for multiple choice questions only. It is appreciated by teachers due to convenient marking, but it does not motivate students to think critically about new ideas. On the other hand, in a conventional mode of teaching, students get qualitative feedback not only in assignments, but also in classroom discussions. This interaction is missing in an online education system. To bridge this gap, certain platforms have been introduced in online education.

In online education, various platforms have been introduced, like discussion boards that make it possible for students to communicate with their teachers and ask subject-related and general queries. Such platforms help students remain active throughout the semester, and they get confidence through these interactions. These are also helpful to take students out of a passive learning environment by asking new questions from teachers. These discussion platforms help students interact with other students, which helps in learning and confidence building. Discussion boards give a feeling of classroom sharing and build a community of learners by studentstudent interaction (AlJeraisy, Mohammad, Fayyoumi, \& Alrashideh, 2015).

Education can be effectively transformative when teachers and students synthesise and share information related to subjects and experiences with each other. Teachers are capable to inculcate critical learning among students and are fortified to improve their abilities of analysis, creativity, and self-awareness. Anna Sun and Xiufang Chen (2016) argued that a successful system of online education depends on the designed content, inspired communication between the instructors and students, and a supportive system of communication. As they further added, what should be developed is an online educational community that motivates ongoing conversation of operative plans that can improve faculties' and universities' achievements in transitioning to online teaching.

The online education system has been getting popular all over the world. Flexible education settings have been incorporated by distance education system to facilitate the quality education and learning opportunities to the public. The learning tools of distance learning enable students and teachers to bridge the learning gap due to geographical dissemination (Nsiah \& Oti-Boadi, 2015).

Online education is becoming more popular due to its easy access to content, instructions, and guidance. It can provide an opportunity to learn for persons who cannot attend the conventional classroom. The online learning system provides the best forum in assembling the informational content more effectively. Kathleen J. Marino (2012) explored the faculty viewpoint and the faculty's adaptation of social presence in the online system. It has been found that faculty members of the online education system interact effectively with students by replying 
to their queries, but have less intimacy. The faculty members are required to develop a balance between intimacy and interactivity by trying different means like video chats.

J. Mateo and A. Sangra (2007) claimed that quality of learning not only depends on the success of students, but is also related to the effectiveness of instructions that have been given by the instructors. They emphasised the need of improvement in the assessment method of distance education and recommended to focus on students' learning through the process of feedback. Muntajeeb Ali Baig (2011) found in his research that the achievement of students in an online learning environment is higher than in the face-to-face learning conditions. He further added that interaction among students and teachers in face-to-face learning system is limited whereas students can interact in online learning environment more effectively and receive guidance along with the valuable content, so an online teaching system makes learning process more centred.

The educated and skilled manpower is crucial for social and economic development of any state. In this regard, universities have adopted open and distance learning systems to give education and skill to the students. Bogadi NageSibande and Bantu Lulu Morolong (2018) conducted a case study at University of Botswana and found that universities are required to change their action plans with reference to open and distance learning systems and enhance this system to create uniformity between open / distance systems and face-to-face facility. This is achieved with improving the communication facility among teachers and students.

The Virtual University of Pakistan is completely based on modern information and communication technologies. It is promoting an equal opportunity of standard education to all Pakistani, even abroad. In view of the lack of qualitative interaction between students and teachers, a platform of MDB (Moderate Discussion Board) has been introduced. This platform provides an opportunity for students to ask the course instructor a subject / lesson related query. Students can ask any subjectrelated or semester activity related question through MDB. Students can also post their own comments in response to other students' queries. MDBs are replied to on priority basis by course instructors to give immediate responses to students.

This research was aimed at investigating the effectiveness of MDB as an interaction platform between students and course instructors at the Virtual University of Pakistan. The effectiveness of MDBs was measured through analysing the number of MDBs posted in a certain course and nature of questions asked in MDBs by students.

\section{Research objectives:}

- to find out the frequency of MDBs asked by the students in one semester,

- to find out the nature of questions being asked by students in MDB.

\section{Research methodology:}

It was a quantitative study in which two Mass Communication subjects were selected through purposive sampling. MDBs of two subjects of Mass 
Communication MCM101 (Introduction to Mass Communication) and MCM301 (Communication Skills) for eight semesters - from Spring 2014 to Fall 2017 - were studied. The rationale of selecting these subjects is similarity as one of the basic subjects with maximum enrolment. This research studied the frequency and nature of asked questions through MDB in these courses.

\section{Data Analysis}

Figure 1 shows the number of enrolled students in MCM101 in each semester and the number of MDBs asked by the students.

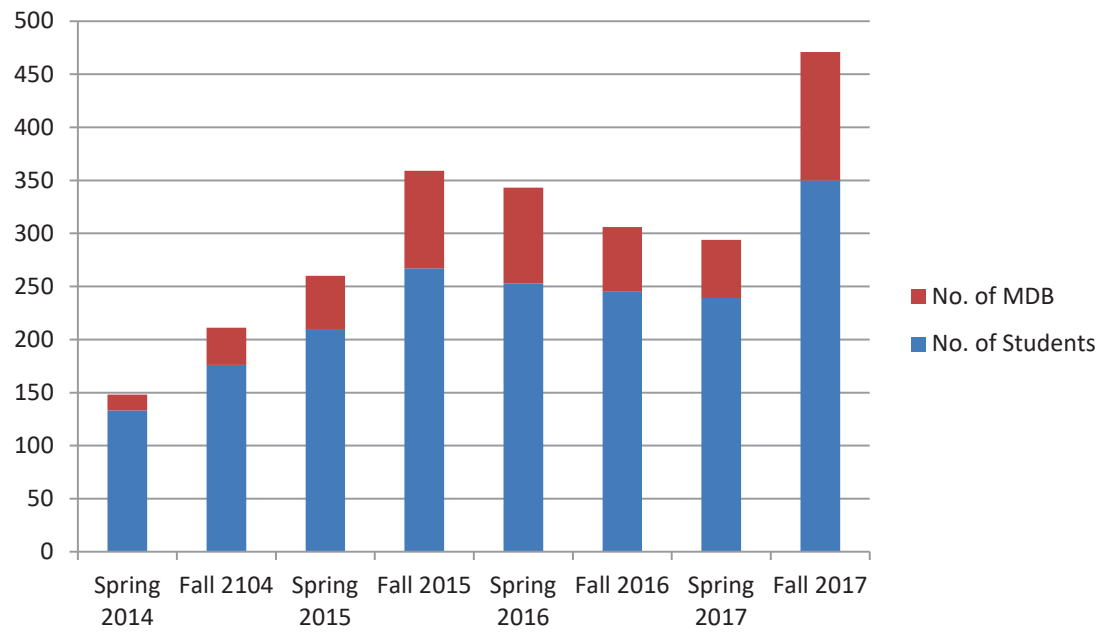

Figure 1. Ratio of MDBs asked to the number of enrolled students in MCM101.

S o u r c e : Data collected from Virtual University Learning Management System (Course Interface).

As can be seen in Figure 1, the number of enrolled students increased until the Fall 2015 semester, and there is a decrease in enrolment in Spring 2016, Fall 2016, and Spring 2017; in turn, Fall 2017 has the maximum number of enrolled students - 350. Similarly, the number of asked MDBs was highest in the Fall 2017 semester - it equalled 121. The data shown in Figure 2 and Table 2 indicate that the number of asked MDBs is also increasing with the increase in students in MCM101. 
Table 1.

Ratio of MDBs asked to the number of enrolled students in MCM101

\begin{tabular}{lcc}
\hline \multicolumn{1}{c}{ Semester } & No. of MDB & No. of enrolled students \\
\hline Spring 2014 & 15 & 133 \\
Fall 2014 & 35 & 176 \\
Spring 2015 & 51 & 209 \\
Fall 2015 & 92 & 267 \\
Spring 2016 & 90 & 253 \\
Fall 2016 & 61 & 245 \\
Spring 2017 & 55 & 239 \\
Fall 2017 & 121 & 350 \\
\hline
\end{tabular}

S o u r c e: Data collected from Virtual University Learning Management System (Course Interface).

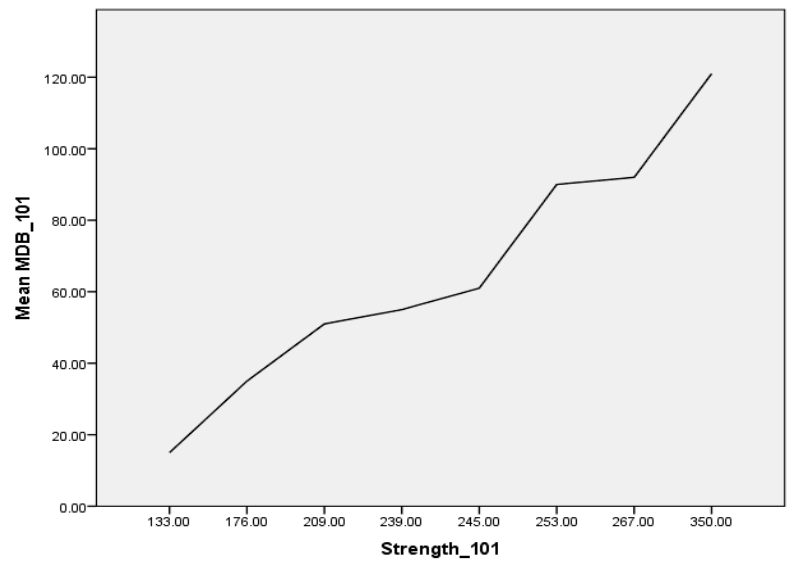

Figure 2. Correlation of MDBs asked to the number of enrolled students in MCM101.

S o u r c e : Data collected from Virtual University Learning Management System (Course Interface).

Table 2.

Correlation of MDBs asked to the number of enrolled students in MCM101

\begin{tabular}{llrr}
\hline & & Strength_101 & MDB_101 \\
\hline \multirow{2}{*}{ Strength_101 } & Pearson Correlation & 1 & $.963^{* *}$ \\
& Sig. (2-tailed) & .000 \\
& $\mathrm{~N}$ & 8 & 8 \\
& Pearson Correlation & $.963^{* *}$ & 1 \\
MDB_101 & Sig. (2-tailed) & .000 & 8 \\
& $\mathrm{~N}$ & 8 & \\
& $* *$ & Correlation is significant at the 0.01 level (2-tailed).
\end{tabular}

S o u r c e: Data collected from Virtual University Learning Management System (Course Interface). 


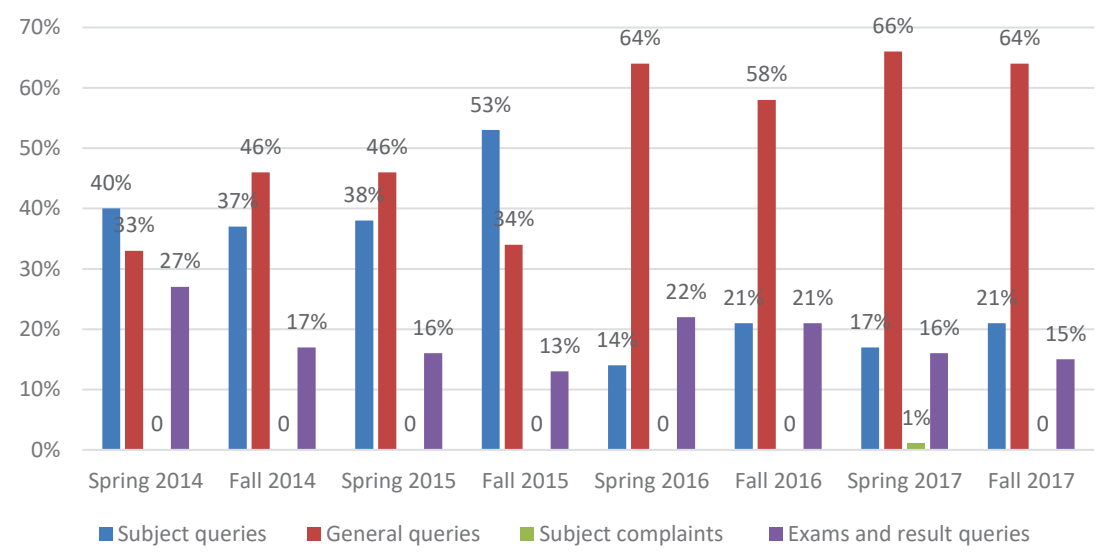

Figure 3. Semester wise MDB data of MCM101.

S o u r c e: Data collected from Virtual University Learning Management System (Course Interface).

Various categories of queries in the MDB have been assigned the following values:

- subject queries,

- general queries,

- subject complaints, and

- exams and result queries.

Table 3 shows the data obtained in four categories of MDB queries in semester wise and presents the questions asked by students on MDB with reference to the abovementioned four categories.

As shown in Table 3, in Spring 2014, students asked 40\% queries related to the subject's content, $33 \%$ students asked about general queries, $27 \%$ - about exams related queries, and no complaint was found. In Fall 2014, 37\% of MDB queries were asked about subject related issues, $46 \%$ were about general matters, and $17 \%$ of queries concerned exams; no issue was found with reference to the subject. In Spring 2015, students asked 38\% queries about the content of the subject, and $46 \%$ queries were related to the general concerns regarding the subject; no complaints were found. In Fall 2015, 53\% of queries were found related to the subject, $34 \%$ of general queries were asked, and $13 \%$ of queries were asked about exam related issues; no complaints were found. In Spring 2016, 14\% of students asked subject related queries, $64 \%$ asked about general issues, and $22 \%$ asked queries related to exams; no query was found related to the subject complaints. In the Fall 2016 semester, 21\% of students asked subject related queries, 58\% asked general queries, and $21 \%$ - exam and result related queries; no complaints were found in this semester. In Spring 2017, 17\% of students asked about subject related issues, $66 \%$ asked general queries, $16 \%$ posted exam and result related queries, and 1\% complained about the course issue. In Fall 2017, $21 \%$ of queries 
were related to the subject's content, $64 \%$ were of general queries, and $15 \%$ were asked about the exams and results issues by the students.

Table 3.

Code sheet of MCM101

\begin{tabular}{ccccccc}
\hline & & & \multicolumn{3}{c}{ Categories } \\
S. No. & ID & Semester & $\begin{array}{c}\text { Subject } \\
\text { queries } \\
\text { (series 1) }\end{array}$ & $\begin{array}{c}\text { General } \\
\text { queries } \\
\text { (series 2) }\end{array}$ & $\begin{array}{c}\text { Subject } \\
\text { complaints } \\
\text { (series 3) }\end{array}$ & $\begin{array}{c}\text { Exams and result } \\
\text { queries (series 4) }\end{array}$ \\
\hline 1 & 1 & Spring 2014 & $6(40 \%)$ & $5(33 \%)$ & 0 & $4(27 \%)$ \\
2 & 1 & Fall 2014 & $13(37 \%)$ & $16(46 \%)$ & 0 & $6(17 \%)$ \\
3 & 1 & Spring 2015 & $19(38 \%)$ & $23(46 \%)$ & 0 & $8(16 \%)$ \\
4 & 1 & Fall 2015 & $50(53 \%)$ & $32(34 \%)$ & 0 & $12(13 \%)$ \\
5 & 1 & Spring 2016 & $12(14 \%)$ & $57(64 \%)$ & 0 & $19(22 \%)$ \\
6 & 1 & Fall 2016 & $13(21 \%)$ & $35(58 \%)$ & 0 & $13(21 \%)$ \\
7 & 1 & Spring 2017 & $10(17 \%)$ & $35(66 \%)$ & $1(1 \%)$ & $9(16 \%)$ \\
8 & 1 & Fall 2017 & $30(21 \%)$ & $87(64 \%)$ & 0 & $22(15 \%)$ \\
\hline
\end{tabular}

Note: Serials depict categories of student queries in MDB

Key: ID: for identification of the subjects, value 1 will be assigned to MCM101, MCM301=2; semester: Spring 2014=1, Fall 2014=2, Spring 2015=3, Fall 2015=4, Spring 2016=5, Fall 2016=6, Spring 2017=7, Fall $2017=8$.

S o u r c e: Data collected from Virtual University Learning Management System (Course Interface).

\section{MCM301}

Figure 4 and Table 4 show that there is an increase in the number of enrolled students from Spring 2014 to Fall 2017.

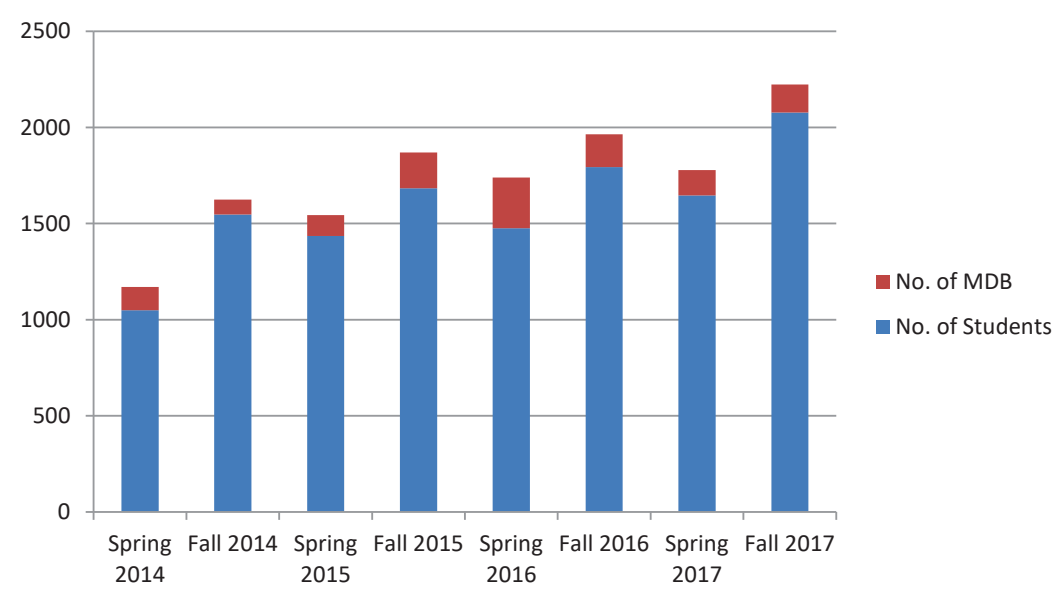

Figure 4. Ratio of MDBs asked to the number of enrolled students in MCM301.

S o u r c e : Data collected from Virtual University Learning Management System (Course Interface). 
Table 4.

Ratio of MDBs asked to the number of enrolled students in MCM301

\begin{tabular}{lcc}
\hline \multicolumn{1}{c}{ Semester } & No. of MDB & No. of enrolled students \\
\hline Spring 2014 & 120 & 1050 \\
Fall 2014 & 78 & 1547 \\
Spring 2015 & 108 & 1436 \\
Fall 2015 & 185 & 1684 \\
Spring 2016 & 263 & 1476 \\
Fall 2016 & 172 & 1793 \\
Spring 2017 & 132 & 1647 \\
Fall 2017 & 145 & 2078 \\
\hline
\end{tabular}

S o u r c e: Data collected from Virtual University Learning Management System (Course Interface).

The Fall 2017 semester has the highest number of students enrolled in MCM301, whereas the highest number of MDBs asked by students was 263 in Spring 2016. One can observe that there is a decline in asking MDB by the students enrolled in MCM301. As can be seen in Figure 5 and Table 5, there is an increase in the number of enrolled students, but the number of MDBs asked by students is not increasing in accordance.

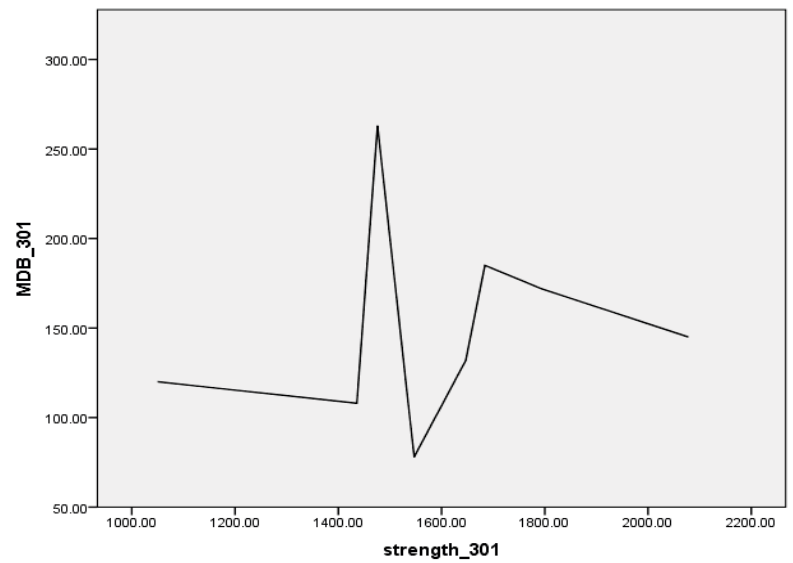

Figure 5. Correlation of MDBs asked to the number of enrolled students in MCM301. S o u r c e : Data collected from Virtual University Learning Management System (Course Interface). 
Table 5.

Correlation of MDBs asked to the number of enrolled students in MCM301

\begin{tabular}{cccc}
\hline & & strength_301 & MDB_301 \\
\hline \multirow{4}{*}{ strength_301 } & Pearson Correlation & 1 & .145 \\
& Sig. (2-tailed) & & .732 \\
& $\mathrm{~N}$ & 8 & 8 \\
\multirow{4}{*}{ MDB_301 } & Pearson Correlation & .145 & 1 \\
& Sig. (2-tailed) & .732 & \\
& $\mathrm{~N}$ & 8 & 8 \\
\hline
\end{tabular}

S o u r c e: Data collected from Virtual University Learning Management System (Course Interface).

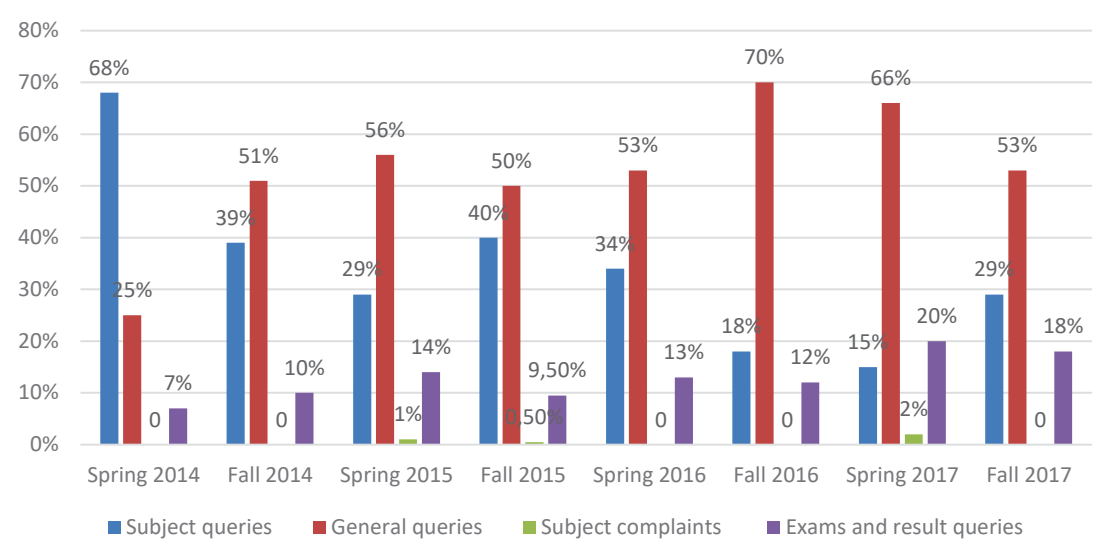

Figure 6. Semester wise data of MCM301.

S o u r c e : Data collected from Virtual University Learning Management System (Course Interface).

Table 6 shows the data obtained in the four categories of MDB queries. In the Spring 2014 semester, $68 \%$ of students' queries were subject queries, $25 \%$ general queries and 7\% - exam and result queries. In Fall 2014, 39\% of queries concerned academic subjects, $51 \%$ - general issues, and $10 \%$ - exams and their results. In Spring 2015, 29\% of queries students asked were subject queries, 56\% general queries, $1 \%$ - subject complaints, and $14 \%$ - exams and result queries. In the Fall 2015 semester, students queries were related to: subject (40\%), general issues $(50 \%)$, complaints $(0.5 \%)$ and exams and results $(9.5 \%)$. In the Spring 2016 semester, $34 \%$ of students' queries were related to subjects, $53 \%$ to general issues, and 13\% to exams and results. In Fall 2016, students asked about subject matters $-18 \%$ of queries, general issues $-70 \%$ of queries, and exams and results $12 \%$ of MDB queries. In Spring 2017, there were $12 \%$ of student queries related to subjects, $66 \%$ of queries concerned general issues, $2 \%$ of queries with complaints, and $20 \%$ of queries about exams and results. In Fall 2017, most queries were about 
general issues (53\%), $29 \%$ of queries were about academic subjects, and $18 \%$ of queries were related to exams and results.

Table 6.

Code sheet

\begin{tabular}{ccccccc}
\hline & & & \multicolumn{4}{c}{ Categories (\%) } \\
S. No. & ID & Semester & $\begin{array}{c}\text { Subject } \\
\text { queries } \\
\text { (series 1) }\end{array}$ & $\begin{array}{c}\text { General } \\
\text { queries } \\
\text { (series 2) }\end{array}$ & $\begin{array}{c}\text { Subject } \\
\text { complaints } \\
\text { (series 3) }\end{array}$ & $\begin{array}{c}\text { Exams and result } \\
\text { queries (series 4) }\end{array}$ \\
\hline 1 & 2 & Spring 2014 & $80(68 \%)$ & $30(25 \%)$ & 0 & $9(7 \%)$ \\
2 & 2 & Fall 2014 & $30(39 \%)$ & $40(51 \%)$ & 0 & $8(10 \%)$ \\
3 & 2 & Spring 2015 & $31(29 \%)$ & $61(56 \%)$ & $1(1 \%)$ & $15(14 \%)$ \\
4 & 2 & Fall 2015 & $73(40 \%)$ & $92(50 \%)$ & $1(0.5 \%)$ & $19(9.5 \%)$ \\
5 & 2 & Spring 2016 & $88(34 \%)$ & $139(53 \%)$ & 0 & $36(13 \%)$ \\
6 & 2 & Fall 2016 & $30(18 \%)$ & $121(70 \%)$ & 0 & $21(12 \%)$ \\
7 & 2 & Spring 2017 & $15(12 \%)$ & $87(66 \%)$ & $3(2 \%)$ & $27(20 \%)$ \\
8 & 2 & Fall 2017 & $41(29 \%)$ & $77(53 \%)$ & 0 & $27(18 \%)$ \\
\hline
\end{tabular}

Note: Serials depict categories of student queries in MDB

Key: ID: for identification of the subjects, value 1 will be assigned to MCM101, MCM301=2; semester: Spring 2014=1, Fall 2014=2, Spring 2015=3, Fall 2015=4, Spring 2016=5, Fall 2016=6, Spring 2017=7, Fall2017 $=8$; categories: various categories in the MDB have been assigned the following values: subject queries (series 1), general queries (series 2), subject complaints (series 3), exams and result queries (series 4).

S o u r c e: Data collected from Virtual University Learning Management System (Course Interface).

From the data obtained it can be concluded that MDB is an effective platform for addressing general queries of students $(51 \%, 56 \%, 50 \%, 53 \%, 70 \%, 66 \%$, and $53 \%$ ), followed by students' subject queries (68\%, 34\%, 39\%, and 40\%). MDBs to some extent address students' queries related to exams and results $(18 \%, 20 \%$, $14 \%$ ), which indicates additional guidance provided to students through MDB.

\section{Discussion and Conclusion}

It can be concluded from the data that MDB is an effective platform for addressing general queries of students. Data analysis shows that not only do students use MDB to ask questions related to lessons, but also the platform provides an opportunity for students to ask exam related queries and questions of general nature. The ratio of asked MDBs to enrolled students is quite low. In Spring 2015, 1,436 students were enrolled in MCM301, but only 95 MDBs were received 
throughout the semester. However, there is an increase in asked MDBs, as it was highest in Spring 2016 - the semester with 263 MDBs and 1,476 enrolled students. In turn, in MCM101 the highest number of MDBs was 121 with 350 students. Results show that the number of MDBs asked by students in MCM301 is decreasing, whereas the number of MDBs is increasing with the increase in enrolled students in each semester. The data analysis shows that the ratio of asking MDB was higher in MCM101 as compared to MCM301.

The data analysis shows that MDB is an effective platform of communication between students and teachers. Lack of relationship building and interaction in online education may seem minor, but they have large effects on teachers and students. Although the opportunity for teachers and students to interact still exists in online education, it is often criticised as a more limited environment that cannot reproduce the same depth of interactions that occur face-to-face. Interpersonal interactions are considered to be essential by many educators and learners. These types of interaction can help learners and instructors develop a feeling of community and connectedness to the course.

In virtual systems, the communication bonding between a student and a teacher is not strong. Students depend on one-way communication in the form of recorded lectures, published announcements, and information given on the website. Bridging the communication gap between students and teachers through MDB is an effective step taken by the Virtual University of Pakistan in online education, as students can ask subject related and general queries.

\section{References}

Akyol, Z. \& Garrison, D. R. (2009). Community of inquiry in adult online learning: Collaborative constructivist approaches. In T. T. Kidd (Ed.), Adult learning in the digital age: Perspectives on online technologies and outcomes (pp. 65-83). Hershey, PA: IGI Global.

AlJeraisy, M. N., Mohammad, H., Fayyoumi, A., \& Alrashideh, W. (2015). Web 2.0 in education: The impact of discussion board on student performance and satisfaction. The Turkish Online Journal of Educational Technology, 14(2), 247-258.

Baig, M. A. (2011). A critical study of effectiveness of online learning on students' achievement. I-manager's Journal of Educational Technology, 7(4), 28-34. DOI: 10.26634/jet.7.4.1391.

Chang, F. C.-I. (2002). Intelligent assessment of distance learning. Information Sciences, 140(1), $105-125$.

Keegan, D. (1996). The foundation of distance education. London: Croom Helm.

Marino, K. J. (2012). A qualitative study exploring faculty perception and adaptation of social presence in the online classroom. Dissertation. Seton Hall University Dissertations and Theses (ETDs), 1796. Accessed 5 May 2018. Retrieved from https://scholarship.shu.edu/dissertations/1796. 
Mateo, J. \& Sangra, A. (2007). Designing online learning assessment through alternative approaches: Facing the concerns. Accessed 5 May 2018. Retrieved from http://www.eurodl .org/?keyword $=$ online $\% 20$ learning\&article $=294$.

Nage-Sibande, A. \& Morolong, B. (2018). A trend analysis of opportunities and challenges of open and distance learning provision in dual-mode institutions. Distance Education, 39(4), 495-510. Accessed 15 April 2018. Retrieved from https://www.tandfonline.com/doi/full/10.1080 /01587919.2018.1457951?scroll=top\&needAccess $=$ true.

Nsiah, G. \& Oti-Boadi, M. (2015). Assessing the effectiveness of distance education within the context of traditional classroom. Creative Education, 6, 707-710. Accessed 15 April 2018. Retrieved from https://file.scirp.org/pdf/CE_2015051915571007.pdf.

Sun, A. \& Chen, X. (2016). Online education and its effective practice: A research review. Journal of Information Technology Education: Research, 15, 157-190. Accessed 15 April 2018. Retrieved from http://www.informingscience.org/Publications/3502.

Terzİ, S. \& Çelïk, A. (2005).Teacher-student interactions in distance learning. The Turkish Online Journal of Educational Technology, 4(1), 54-56.

Tu, C.-H. \& McIsaac, M. (2002). The relationship of social presence and interaction in online classes. The American Journal of Distance Education, 16(3), 131-150.

York, C. S. \& Richardson, J. C. (2012). Interpersonal interaction in online learning: Experienced online instructors' perceptions of influencing factors. Journal of Asynchronous Learning Network, 16(4), 83-98.

Nadia Saleem, Aisha M Din, Saba Sadiq, Masroor Ahmed

\section{MDB jako efektywna platforma komunikacji między uczniami a nauczycielami: studium z Uniwersytetu Wirtualnego w Pakistanie}

\section{Streszczenie}

Integracja nauczania na odległość oraz technologii komunikacyjnych i informacyjnych stała się źródłem wielu udogodnień dla uczniów, którzy wcześniej doświadczali problemów z edukacją z powodu ograniczeń czasowych lub geograficznych. Ponieważ e-learning jest pojęciem nowym i odmiennym, dyskurs dotyczący metodologii nauczania i relacji uczeń-nauczyciel w środowisku e-learningowym wprowadził wiele nowych elementów wartych omówienia i rozważenia. W systemie wirtualnym powiązanie komunikacyjne miedzy uczniem a nauczycielem nie jest tak mocne jak w systemie klasycznym. Uczniowie muszą polegać na jednostronnej komunikacji w postaci nagranych wykładów, publikowanych ogłoszeń lub informacji zamieszczanych w sieci. Redukowanie luki komunikacyjnej między uczniem a nauczycielem za pomocą MDB (platformy zarządzania dyskusją) jest efektywnym krokiem w zakresie edukacji online podjętym przez Uniwersytet Wirtualny w Pakistanie. Prezentowane w artykule badania miały na celu zbadanie efektywności MDB jako platformy interakcji między uczniami a instruktorami na Uniwersytecie Wirtualnym w Pakistanie. Efektywność MDB mierzono za pomocą analizy liczby MDB wysłanych w ramach danego kursu oraz rodzaju pytań zadawanych za pośrednictwem MDB przez studentów. Przeprowadzono badanie ilościowe, w którym wybrano poprzez losowanie celowe dwa przedmioty z kursu Komunikacji Masowej. Dane zebrano i poddano analizie procentowej, a także zastosowano statystyczny test korelacji, aby stwierdzić, czy istnieje zależność między liczbą uczniów a pytaniami zadawanymi poprzez MDB. Stwierdzono, że chociaż liczba MDB jest niższa od liczby uczniów, którzy zapisali się na kurs, to jednak MDB stanowi efektywną platformę komunikacji między uczniem a nauczycielem. Dzieje się 
tak, ponieważ uczniowie mogą zadawać pytania odnoszące się do przedmiotu, egzaminów, aktywności w semestrze oraz spraw ogólnych.

S łow a kluc z ow e: e-learning, MDB, luka komunikacyjna, system wirtualny

Nadia Saleem, Aisha M Din, Saba Sadiq, Masroor Ahmed

\section{Модерируемая доска обсуждений (MDB) как эффективная платформа общения студентов и преподавателей: исследование виртуального университета Пакистана}

\section{Анн но т а и я}

Интеграция дистанционного обучения и информационно-коммуникационных технологий принесла много удобства студентам, которые ранее сталкивались с проблемами в образовании из-за временных и географических ограничений. Поскольку концепция электронного обучения является сравнительно новой, дискурс в области методологии преподавания и взаимоотношениям учителей и учеников в среде электронного обучения привел к обсуждению многих новых аспектов. В виртуальной системе связь между учеником и учителем не так сильна. Студенты зависят от одностороннего общения в форме записанных лекций, опубликованных объявлений и информации, представленной на веб-сайте. Преодоление разрыва в общении между учеником и преподавателем с помощью MDB (модерируемая доска обсуждений) - это эффективный шаг, предпринятый Виртуальным университетом Пакистана в онлайн-образовании для решения проблем студентов. Это исследование было направлено на изучение эффективности MDB как платформы взаимодействия между студентами и преподавателями курса в Виртуальном университете Пакистана. Эффективность MDB измерялась путем анализа количества сообщений, опубликованных в определенном курсе, и характера вопросов, задаваемых студентами. Это было количественное исследование, в котором 2 предмета из массовых коммуникаций были отобраны путем целенаправленной выборки. Собранные данные были проанализированы в процентах, и был применен статистический коррелиционный анализ, чтобы выяснить, есть ли какая-то связь между уровнем студента и вопросом, задаваемым через MDB. Исследование показало, что, хотя число вопросов в MDB значительно меньше, чем зачисленных студентов, тем не менее, это эффективная платформа общения между учениками и преподавателями, поскольку студенты могут задавать вопросы, связанные с предметом, экзаменами, семестровой деятельностью и общими проблемами.

К л ю ч е в ы е с л о в а: электронное обучение, модерируемая доска обсуждений (MDB), коммуникационный разрыв, виртуальная система 
Nadia Saleem, Aisha M Din, Saba Sadiq, Masroor Ahmed

\section{MDB como plataforma efectiva de comunicación entre estudiantes y profesores: un estudio en la Universidad Virtual de Pakistán}

Resumen

La integración de la enseñanza a distancia y las tecnologías de la Información y de la Comunicación ha generado viabilidad a los estudiantes que antes tenían dificultades debido a las limitaciones de tiempo y espacio. Considerando que el concepto de e-learning es relativamente nuevo, el discurso sobre las metodologías de enseñanzas y la relación que se establece entre el profesorado y el alumnado ha generado nuevas perspectivas de análisis. En la enseñanza virtual hay dificultades en la relación entre docentes y alumnado. Los estudiantes dependen de la comunicación establecida en una sola dirección en forma de clases grabadas, material publicado y la información en la web. Eliminar los problemas de comunicación entre el profesorado y el alumnado a través de MDB (Moderate Discussion Board) es un objetivo de la Universidad Virtual de Pakistán en sus cursos virtuales. Esta investigación tuvo como objetivo investigar la eficacia de MDB como plataforma de interacción entre estudiantes y docentes en la Universidad Virtual de Pakistán. La eficacia de los MDB se midió a través del análisis de la cantidad de MDB publicados en un curso determinado y la naturaleza de las preguntas formuladas en los MDB por los estudiantes. El estudio es cuantitativo en el que se seleccionaron 2 asignaturas de Mass Communication a través de un muestreo intencional. Los datos recopilados se analizaron en porcentajes y a través de una prueba de correlación para determinar si existe alguna relación entre las competencias de los estudiantes y las preguntas formulada a través de MDB. Los resultados muestran que el número de MDB es bastante inferior al de los estudiantes matriculados, sin embargo, resultó una plataforma eficaz de comunicación entre estudiantes y docentes, ya que los estudiantes pueden hacer preguntas relacionadas con la materia, los exámenes, las actividades del semestre y sobre cuestiones generales.

P a labras clave: e-learning, MDB, brecha de comunicación, sistema virtual 



\section{II \\ Innovative Models, Methods, and Means in Electronical Education}





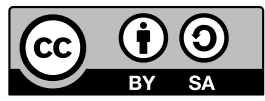

DOI 10.31261/IJREL.2018.4.2.06

\title{
Svetlana Skvortsova
}

Ukraine (ORCID: 0000-0003-4047-1301)

\section{Maryna Haran}

Ukraine (ORCID: 0000-0002-7438-126X)

\section{The Multimedia Presentation of a Lecture as the Means of Perception, Comprehension, and Memorisation of Educational Information by Students}

\begin{abstract}
The demand for teachers of Ukrainian universities to create multimedia presentations of lectures and their use in the process of teaching the course "Methodology of teaching mathematics" has been formulated as the result of the experimental research. Taking into account the specificity of the discipline and the peculiarities of the perception, comprehension, and memorisation of educational information by students, what has been determined are the requirements for visual and audio content, for the text presented on presentation slides, and for the design and navigation, and their effectiveness has been experimentally proved. In particular, it has been established that, in order to facilitate students' perception of educational information, presentation slides should not contain large text arrays. Text slices of presentations should be executed using a certain font, with a certain font size and dominant colours of the headings and main text. To facilitate understanding and memorisation of the content of teaching, the theoretical information should be structured and presented in the form of circuits, tables, diagrams, etc. To stimulate interest in learning, a positive emotional background should be created, and thus a presentation should contain bright colour objects, photographs, and video footage of real mathematics lessons. It is emphasised that, in order to create conditions for the perception, understanding, and memorisation of educational information, presentation design should provide a single style of
\end{abstract}


design and identical compositions of components; for example, image of the same type of information should be in the form of identical elements of "SmartArt."

K e y w ords: teacher training, methodology of teaching mathematics, lecture, multimedia presentation

\section{Introduction}

The current stage of the development of primary education in Ukraine is characterised by the implementation of the concept of reforming general secondary education "New Ukrainian School," the new State Standard of Primary Education, and new Typical Educational Programmes for 1-2 forms, which brings up to date the problem of upgrading the content and methods of training future primary school teachers, and the effectiveness of this training.

The training of a primary school teacher for teaching mathematics takes place in the process of mastering the course "Methodology of teaching mathematics at primary school," which provides lectures and practical / laboratory classes. In order to study the teaching tools used by university lecturers in teaching the course "Methodology of teaching mathematics," we conducted an experiment. Twenty lecturers of this subject were included in the study (South Ukrainian National Pedagogical University named after K. D. Ushynsky in Odessa, Kherson State University, Berdyansk State Pedagogical University, Mykolaiv National University named after V. Sukhomlynsky, Vasyl Stefanyk Precarpathian National University, Chernihiv National Pedagogical University named after T. Shevchenko, Ivan Franko National University of Lviv, Cherkasy National University named after B. Khmelnytsky, Pavlo Tychyna Uman State Pedagogical University, National Pedagogical Dragomanov University in Kyiv, Sumy State Pedagogical University named after A. Makarenko, Hlukhiv National Pedagogical University named after O. Dovzhenko, Khmelnytsky Humanitarian Pedagogical Academy, Lviv regional institutes of postgraduate pedagogical education, Zaporizhzhya regional institutes of postgraduate pedagogical education, Cherkasy regional institutes of postgraduate pedagogical education, Kherson Academy of Continuing Education and Odessa Institute of Teacher's Training). Questionnaires were suggested in order to make it possible for the academic teachers to indicate which means of information technologies they use during their lectures, as well as to express their views on the need of multimedia presentations of lectures.

The survey results showed that most teachers during their teaching of methodology of teaching mathematics use a lot of educational materials, both electronic and non-electronic: the texts of lectures in paper (70\%) and electronic 
$(60 \%)$ form, material visualisation (55\%) and schematic visualisation (35\%), paper textbooks on mathematics $(75 \%)$ and methodology of teaching mathematics at primary school (90\%), study guides $(65 \%)$, electronic textbooks on methodology of teaching mathematics $(45 \%)$ and electronic study guides $(50 \%)$, paper copies of normative documents $(60 \%)$ and their electronic versions $(65 \%)$. They also offer links to the pages of the MONU (65\%), and show students the programme of the course in paper $(60 \%)$ and electronic $(50 \%)$ form. A significant number of teachers use presentations of lectures $(80 \%)$ and video materials $(80 \%)$. Yet these presentations, although being done in MS PowerPoint, mostly represent the lecture theses in the textual form, ready samples of the solution.

All teachers who participated in the survey (100\% of respondents) are sure that increasing the effectiveness of students' learning of methodology of teaching mathematics can be achieved by learning materials developed on the basis of information technologies. In addition, most teachers (95\%) are sure of the feasibility of using information technologies precisely during lectures. Thus, we confirmed the relevance of the development of learning tools based on IT, in particular, multimedia presentations of lectures with animation, as the result of the experiment.

Proceeding from the fact that teaching mathematics at primary school is realised with the involvement of a big number of distribution materials, with which pupils perform practical actions in the process of studying, and that it is carried out using objective and schematic visualisation, it becomes obvious that during lectures a teacher should demonstrate the method of working with these tools to students. At the same time, the use of distribution materials and visual materials in the material form requires a lot of time and does not allow the lecturer to demonstrate the qualitative method of working with them. Thus, the question of illustrating the work of visualisation appears, which is possible with the use of multimedia presentations of lectures. In a multimedia presentation with the help of animation effects, it is possible to imitate the work of students with distribution materials and other means of visualisation, distinguishing key steps, gradually performing the required entries.

An essential feature of the modern stage of primary education is variability - the variability of forms and methods of teaching and, most importantly, the variability of textbooks, the variability of calendar and thematic plans, the variability of methodological support, etc. Therefore, during the lecture, the teacher has to appeal to valid textbooks, manuals, lesson development, etc., showing their pages. The use of paper books during the lecture does not allow the teacher to demonstrate students the page in an enlarged form or to compare the specific tasks of one textbook consistently, as well as the corresponding tasks from the textbooks of different authors; the teacher has to spend time finding the right pages, and students have no way to look at them in detail. Overcoming these disadvantages is possible by means of using multimedia presentations in which electronic versions of paper textbooks, manuals, normative documents could be replaced by providing hyperlinks to them. 
The consideration of methodological approaches to teaching a particular programme issue to primary school pupils should be accompanied by a large number of structural schemes and records of solutions of certain tasks during the lecture. Moreover, colour separations are desirable, which require a lot of time for the teacher to prepare. A multimedia presentation will allow to accelerate the lecture rate significantly, in which records can be similarly deployed with animation, which makes it possible to demonstrate to students only those fragments of the solution which they have already understood. In this way, students' cognitive activity is stimulated by facilitating the perception, analysis, and awareness of the information through the colour highlighting, movements, and other visual effects.

In addition, multimedia presentations can also include audio and video files such as videos of maths lessons, illustrating the methodical reception or implementation of a particular learning technology, etc. Such wide opportunities make the multimedia presentation a universal means of teaching methodology of teaching mathematics.

That is why all the interviewed lecturers expressed the need to use multimedia presentations of lectures on methodology in teaching mathematics. However, despite the teachers' awareness of the necessity and appropriateness of using information technologies in the process of teaching mathematics, only $20 \%$ of respondents confirm that presentations are always used during lectures. In our opinion, this is due primarily to the fact that not all teachers understand completely the possibilities of using information technologies during classroom work for students' acquisition of the material, and most importantly - many of them lack skills and experience in creating such presentations.

\section{Multimedia Presentation of the Lecture on the Methodology of Teaching Mathematics}

\section{The Lecture on the Methodology of Teaching Mathematics}

To stimulate cognitive activity of students, we use a problem lecture on the methodology of teaching mathematics at primary school. The problem lecture is based on the principle of personal learning, aimed at developing the creative possibilities of students. The teacher of methodology of mathematics teaching should acquaint students with the available methodological techniques, formed as the result of the functioning of various educational systems and the variability of educational and methodological complexes, in particular, from the initial course of mathematics, to perform their comparative analysis, to outline the problem "What methodological approach is most effective for forming a certain notion, skill, 
or ability of primary school pupils?" At the same time, the lecturer must provide the students with the opportunity to choose their personal positions, encouraging them to give their own judgments.

In our study, we follow the plan of the problem lecture on the methodology of teaching mathematics developed by Svetlana Skvortsova and Yana Haievets (2013). This plan covers the following stages: motivation of students' educational activity; creating a problem situation, outline of the problem; analysis of the given problem, which consists in studying various methodological approaches; forming proposals, expressing a hypothesis. After mastering the content of the lecture by the student, comparing the outlined methodological approaches, drawing up their comparative characteristics, the student must make his or her own decision in choosing the most expedient and effective approach.

It should be mentioned that even despite the problem nature of the lecture on the methodology of teaching mathematics, a number of didactic problems are taken from real situations since they appear in the practice of conducting lectures in higher professional education. This problem is associated with using mainly one channel of perception ("hearing"), with the significant amount of information offered to students in conjunction with the insufficient level of its structuring, with a static form of presentation of information, which complicates the flexible adaptation to changes in the content of education, with a large number of listeners at the lecture and the conservative form of lecture classes, etc. One of the most effective means of correcting the abovementioned disadvantages of the traditional lecture is creating multimedia presentations of lectures on the methodology of teaching mathematics.

Valery Viun, Iryna Huz, Mykola Shyshlakov, and Alexiy Demydenko (2012) found that using predominantly a single channel of perception by a teacher does not ensure the adequate comprehension of the educational material - the main amount of information should be understood by the student "by hearing" (which provides another complexity - inaccurate and fuzzy drawing up of notes). This problem can be solved by means of a multimedia presentation of the lecture, which creates opportunities for simultaneous audio and visual perception of students of educational information, due to the presentation of educational content on its slide. The presentation itself is only an auxiliary means, and the lecturer is free in his or her comments. Also, during the multimedia presentation of lectures, students need to make notes before the lecture disappears, as all the teaching material is reflected in the presentation. We also emphasise that the multimedia presentation of the lecture creates the opportunity for students to repeat the lectures aloud after the teacher, to comment on samples of the lecturer's instruction in the process of solving tasks with dynamically deployed solutions using animation effects, and thus to try their own strengths, to master certain speech constructions, to accompany the methodological activity of the teacher, to correct all possible inaccuracies, and to obtain the minimal experience of methodical activity, etc. 
The form of presentation of information is usually static and cannot adapt flexibly to the changes in the content of traditional lecture (Viun, Huz, Shyshlakov, $\&$ Demydenko, 2012). In this context, the possibility to use, during the lecture, the presentation on methodology of teaching mathematics in electronic versions of updated normative support of primary education, hyperlinks to Internet resources, including on the MES website of Ukraine, should be emphasised.

A modern high school lecturer, as a rule, works with numerous student batches - this kind of load also affects the quality of learning (Viun, Huz, Shyshlakov, \& Demydenko, 2012). The multimedia presentation creates conditions for reducing the teacher's workload: the presentation is a means for presenting the content of the lecture on the methodology of teaching mathematics, reflecting its main content, and thus the lecturer has only to comment on the slides of the presentation, without putting any effort to write on the board, and therefore is not distracted by necessary notes and keeps the entire student audience in sight.

We also note that in order to implement a differentiated approach to students, it is possible to use video lectures or multimedia presentations of lectures with a sound commentary to each slide. Under these conditions, students are able to master the content of the lecture at their own pace, returning, if it is necessary, to certain content elements.

The conservative form of lecture classes does not contribute to the active work of students and formation of a subjective position regarding the didactic process (Viun, Huz, Shyshlakov, \& Demydenko, 2012). The problem character of the lecture on methodology of teaching mathematics, as well as presenting educational content on the presentation slides of the lecture and animation effects (colour separations, movements, etc.), facilitates the students' process of perception, comprehension, and memorisation of educational information, and therefore it promotes the activation of educational and cognitive activities of students during the lecture.

\section{Multimedia Presentation of the Lecture}

A presentation as an electronic document is a set of slides (each of which can contain text blocks, graphic elements, and design elements) and special effects that accompany the display on the screen.

There are numerous software tools for creating multimedia presentations (ProShow Producer, MS PowerPoint, OpenOffice Impress, Kingsoft Presentation Free, Corel Show, SmartDraw, etc.); each of them has its own advantages and features (Smyrnova-Trybulska et al., 2015). MS PowerPoint is reasonably considered to be one of the most popular and most used tools. An important argument in favour of MS PowerPoint is the availability of the programme, and lecturers', students', and primary school teachers' elementary skills to work with it (MS PowerPoint is a part of the standard Microsoft Office suite that is used by most government agencies in Ukraine, and it is the subject of study of the school 
computer science course). MS PowerPoint was identified as one of the most effective presentation tools in a comprehensive analysis of 20 programmes for creating presentations according to 26 criteria in the study of Eugenia SmyrnovaTrybulska and other researchers (2016).

It should be noted that - according to the survey data dealing with teaching methods and technologies, conducted at Lethbridge College, Alberta, CA in 2012 MS PowerPoint was selected by $83 \%$ of teachers as the programme used in the educational process. The uptake of this programme in the educational process is in part different in Ukraine. Thus, the analysis of the results of the questionnaire of teachers of methodology of teaching mathematics, conducted by us within the framework of the ascertaining experiment, has shown that $100 \%$ of teachers use MS PowerPoint to create and view presentations. However, although all interviewed teachers $(100 \%)$ agree about the necessity to use presentations during the lectures on the methodology of teaching mathematics, most of them do not do this regularly - only $20 \%$ of respondents confirm that presentations are always used during their lectures. The majority of lecturers use presentations of lectures, and their presentations contain the title slide with the theme (100\%), lecture plan $(100 \%)$, problem issues $(70 \%)$, the reference list $(85 \%)$, the main content of the topic in the form of abstracts $(65 \%)$ or in full $(5 \%)$, and reflection $(50 \%)$. Lecturers often add to their lecture presentations videos of mathematics lessons at primary school $(65 \%)$, fragments from the current textbooks on mathematics $(60 \%)$, fragments of normative documents $(55 \%)$, and examples of ready-made tasks $(55 \%)$. A significantly smaller number of teachers of the methodology of teaching mathematics use visual means of presentation (40\%) or visual means with work simulation with the help of animation effects, with a dynamic demonstration (25\%); examples of the teacher's work on individual tasks with a clear fixing of the steps of the teacher $(40 \%)$ or examples of solving tasks that dynamically unfold in animation (15\%); real pupils' photos at mathematics lessons (30\%).

In our opinion, this is not an entirely optimal use of the possibilities of presentations during lectures, primarily due to the fact that most of the teachers do not have enough knowledge about Microsoft PowerPoint to create them. So, only $30 \%$ of teachers are completely competent in using the programme. The rest use only the basics of MS PowerPoint: use templates (65\%); write the text on slides (75\%); add tables, graphs, charts (65\%); adjust the animation of the transition between slides (50\%); adjust the animation of the text $(45 \%)$; add and format images (45\%); add hyperlinks and control elements (45\%); use "SmartArt" objects (40\%); add video and sound (35\%); and apply animation effects in writing mathematical equation (35\%). Most teachers cannot customise their animation on presentation slides, but they think that animation effects, illustrating actions with visualisation or the process of solving tasks, increase the rate of lectures significantly, visualise their content, and facilitate better understanding of the educational information by students. In addition, it is concluded that those 
teachers who already use presentations at lectures on the methodology of teaching mathematics mostly created them on their own and submitted the main theses of the lecture on the presentation slides, but did not use the means of structuring the theoretical material (tables, flowcharts, "SmartArt" objects, etc.), although $90 \%$ of teachers agreed that the structuring of educational materials in a schematic form facilitates students' perception and comprehension of the educational information significantly.

Thus, taking into account the lecturers' objective need in existing presentation material for lectures, found during the pedagogical experiment, using as an editor which has the best features of MS PowerPoint programme, and with regards to the didactic features of the course, a multimedia presentation of lectures on the educational course "Methodology of teaching mathematics" was developed.

We understand "Multimedia presentation of the lecture on the course 'Methodology of teaching mathematics"' as a presentation in which the educational content is presented in a structured form; methodological approaches are illustrated with colour and animation effects; the methodology of work on certain mathematical problems is given by means of dynamic deployment of the solution; the natural visualisation is replaced by the electronic one, and the methodology of working with it is demonstrated with animation effects; hyperlinks to electronic versions of normative documents and textbooks on mathematics for primary school, and to video fragments of real mathematics lessons at primary school, illustrating an appropriate element of the educational content (structure of a lesson, teaching technology, etc.) are given, as well as video fragments with students' reflections, demonstrating the ways of calculating, work on tasks, etc.

Unlike a regular lecture presentation, which is usually based on linear logic, the multimedia presentation is organised according to the logic of a problematic presentation - it requires a special presentation structure and the presence of hyperlinks (Meixner, 2017).

Developing the structure of the multimedia presentation, we used the problem lecture scheme on the methodology of teaching mathematics of Skvortsova and Haievets (2013), which contains the following compulsory elements: motivation of students' educational activity; creating a problem situation, formulating the problem; analysis of the problem, consisting in the analysis of various methodological approaches; outline of suggestions, hypothesis offering.

Consequently, the multimedia presentation of the lecture on the topic of methodology of teaching mathematics contains separate slides, which include: the topic of the lecture (Figure 1); problem issues that motivate educational and cognitive activity of students at the lecture (Figure 2); reference (Figure 3); the plan of the lecture (Figure 4); presentation of the main content, in accordance with the points of the plan (Figure 5); the slide directing students' activity to the reflection of their own educational activities during the lecture (Figure 6). 


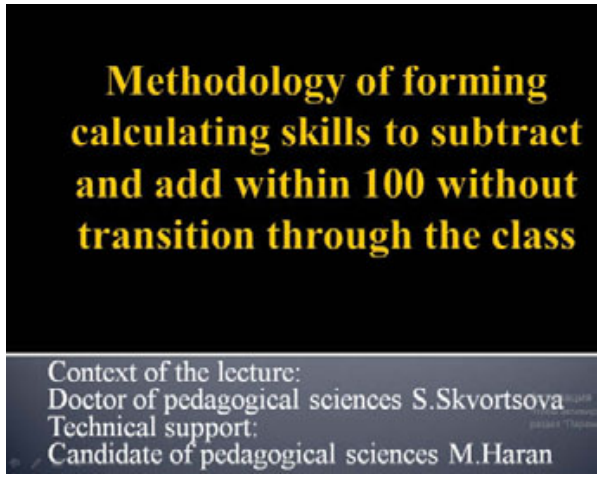

Figure 1. The topic of the lecture.

S ource : Own work.

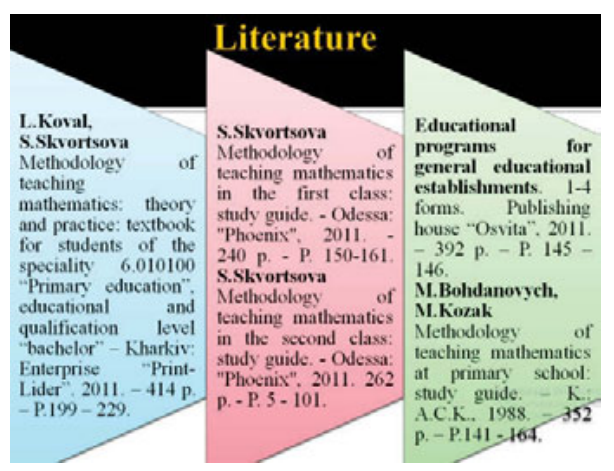

Figure 3. Reference.

S ource : Own work. Adding and subtracting numbers within 100
without passing through the discharge. The dynamics of presentation of cases of calculation

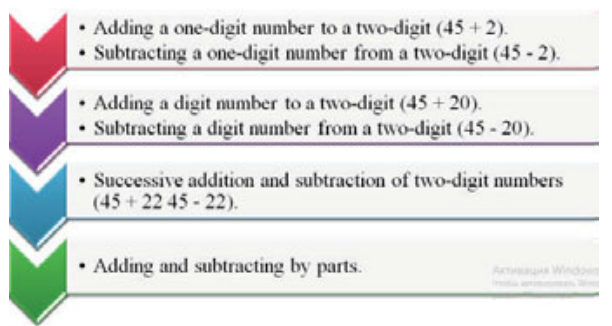

Figure 5. Presentation of the main content, in accordance with the points of the plan.

S o u r c e: Own work.

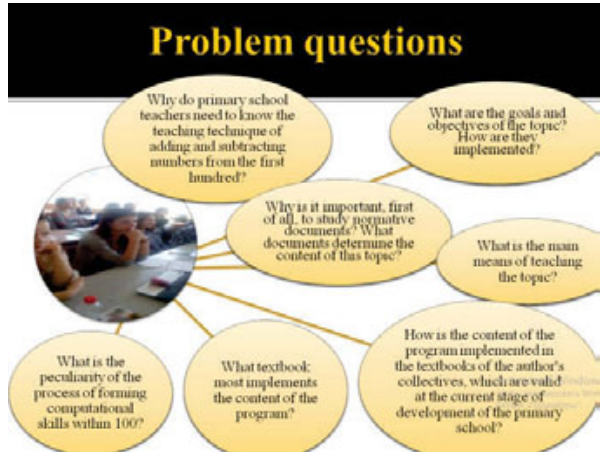

Figure 2. Problem issues.

S o u r c e : Own work.

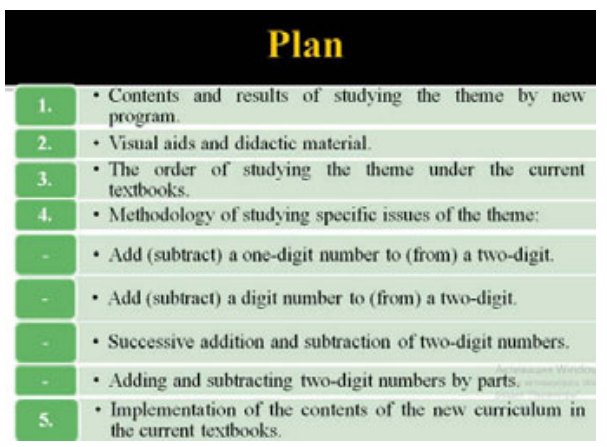

Figure 4. The plan of the lecture.

S our c e : Own work.

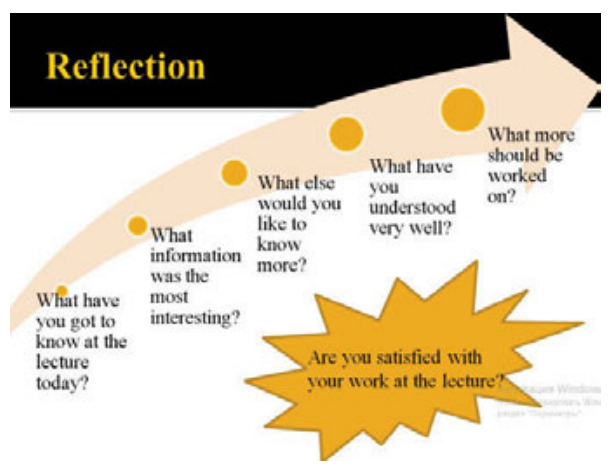

Figure 6. Reflection.

S o u r c e : Own work. 


\section{The Requirements for Multimedia Presentations of Lectures}

Multimedia presentations must meet certain requirements regarding the structure and content of presentation slides, use of fonts and colours, and so on.

The analysis of recent researches has shown that domestic (B. Herasymchuk, N. Morze, N. Dementievska, A. Mokrohuz, S. Ryzhenko, O. Skafa, O. Tutova, Yu. Tkach) and foreign (A. Luzghina, H. Tokarieva, V. Ryzhov) scholars are developing recommendations for the creation of educational multimedia presentations, including presentation of lectures. Existing requirements and recommendations, representing both own experience of the scientists from their developments and the generalised results of individual researches, are mostly general. In this regard, they are not final criteria for creating an effective presentation, since it is not possible to unify a priori recommendations for presentations, related to different branches of knowledge, having different goals, different contingents, etc.

On the basis of the generalisation of the research results (V. Andriievska, N. Olefirenko, N. Morse, N. Dementievska, O. Skafa, A. Tutova, etc.), during the creation of the presentations of lectures on the methodology of teaching mathematics, we have taken into account the general requirements: for the content of the multimedia presentation; for the visual and sound series; for the text; for the design; and for the quality of navigation.

Acquisition of knowledge on any discipline begins with perception, which, as it is known, is affected by the action force of the goad on the senses; thus, it depends on the physical qualities of the object of perception (brightness, dynamism, etc.) and on the physical conditions in which it is perceived (remoteness, visualisation, contrast with the background, etc.). Therefore, the form of representation of educational information and its visual design affect the quality of perception, comprehension, and memorisation of material, and can optimise the understanding of the lecture content.

It is advisable to take into account the peculiarities of the process of perception of information and the means of facilitating the process of perceiving educational information that requires its special design in the process of creating a multimedia presentation (Lin, Leh, Kim, \& Baylen, 2018), namely: the combination of the principle of contrast (contrast, according to psychologists, is the main means of enhancing perception) in the colour of the background and colour of the text on the slides of the presentation; using bright font colour (chromatic colours: red, orange, yellow, green, blue, dark blue, violet, purple should be used to transfer emotionallyevaluative components of information; achromatic colours: white, black and all shades of grey - for information, containing mostly cognitive components).

We consider it necessary to take into account another feature of the participants in the process of perception - gender. Scientists understand the differentiation of development by sex. Nina Yerofieieva, Jean Piaget, Igor Kon, Antonina Khrypkova, and others prove the existence of physiological, intellectual, moral, emotional, and behavioural differences between men and women, which should be emphasised 
during the construction of the educational process. Thus, the physiological features of visual perception are conditioned by the genetic programme of development that motivates the specificity of the duration of mental processes of males and females. For example, women (the students of the direction of training "Primary education" are mostly people of female sex) perceive colours much brighter than men. This confirms that using a wide range of colours in the development of presentations will make it possible to substantiate the content of the training material. In addition, differences in the structure of the brain of men and women prove that women are more emotional and have imaginative thinking more developed than men, so teaching women should be more emotional. One of the ways to create emotional background can be by using bright images, coloured objects, etc. It is possible to cause positive emotions and therefore provide students' motivation to study methodology of teaching mathematics by using photographs of real mathematics lessons at primary school, which demonstrate brightly the emotions and interest of children in learning mathematics in slide presentations (Figure 7). The particular attention should be paid to including video fragments of real mathematics lessons that relate to the topic of the lecture in the presentations (Figure 8).

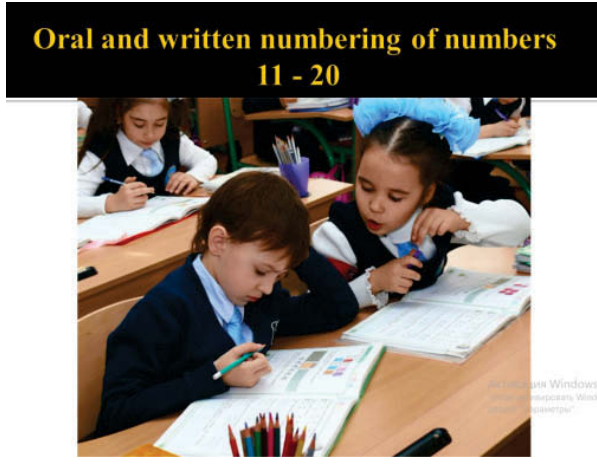

Figure 7. Fragment of the lecture on the topic "Methodology of teaching numeration of the first hundred numbers."
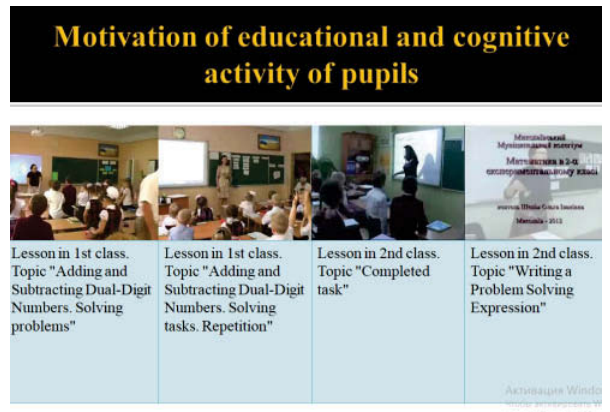

Figure 8. Fragment of the lecture on the topic "Modern Mathematics Lesson at Primary School."

S o u r c e : Own work.

S o u r c e : Own work.

Such intersections create the atmosphere of significance and practicality of the acquired knowledge, which is an impetus for more productive and conscious activity of students and contributes to the formation of the values-based attitude to the received information.

Psychologists state that the brightness and emotional colouring of objects affect spontaneous memorisation - one of the main processes of memory. As it is known, cognitive activity begins with sensations and perception, but all the necessary information is kept in memory. It has been proved in psychology that involuntary 
memorisation is possible even when a phenomenon or an object appears in contrast to the general background, confirming the necessity to choose the colour gamut for the background of the slides and objects, placed on it very carefully.

Yuliia Tkach emphasises that choosing the colour of the presentation background should also take into account the fact that information will be perceived from the screen (TV, interactive whiteboard, projection screen, etc.) during the presentation at the lecture. In the case of a large screen size, it is not recommended to use chromatic colours as background. Typically, lectures on the methodology of teaching mathematics are conducted for the whole students' batch in a large lecture classroom, where there is a large screen. Considering this, it is advisable to choose achromatic colours as a background, namely the black colour for the slide title and the white colour for its working section. The main colour of the font is black, and other colours should be used to highlight the definitions and key concepts, and with a methodical aim (as the illustration of the process of solving tasks, etc., Figure 9).

Writing text information on presentation slides, in addition to the colour of the font, as well as its type, size, etc., it is necessary to follow certain rules, concerning the form of its image, the volume of text blocks, and syntactic features, as work with texts is especially difficult for human eyes.

For example, it is not desirable to use more than two types of fonts on one presentation slide. The Times New Roman and Arial fonts are considered to be the most acceptable, while the use of art fonts can lead to the negative students' reaction due to difficulties in reading, resulting in the weakening of attention and perception (Luzghina \& Tokarieva, 2007). Choosing the font size, we should be focused on the audience size, screen size, age audience features, etc. We consider it appropriate to use for titles such properties as: $36 \mathrm{ctrl}$ for the title slides, 24 for the main text (Figure 10) in the process of creating lecture presentations on the course of the methodology of teaching mathematics.

It is well-known that a solid text, even in the case of voice-over, cannot hold the attention of a listener-viewer for a long time. Instead, attention, or focus on the subject of the study, gives the student the opportunity to use power of thinking and memory to master educational content and ways of action, to ensure successful educational activity. It also should be mentioned that attention is a "weak point" in students' activity. According to the analysis of age characteristics of students, in the age period of 19-21 (the academic subject "Methodology of teaching mathematics" is mainly studied in 2-3 years, the average age of students who master it is 19-21), the cognitive sphere is characterised by a relatively high level of thinking and memory development, while the level of attention development is not high enough then. As noted above, there is a need to stimulate attention when presenting theoretical data, in particular through the structuring and selection of information. 


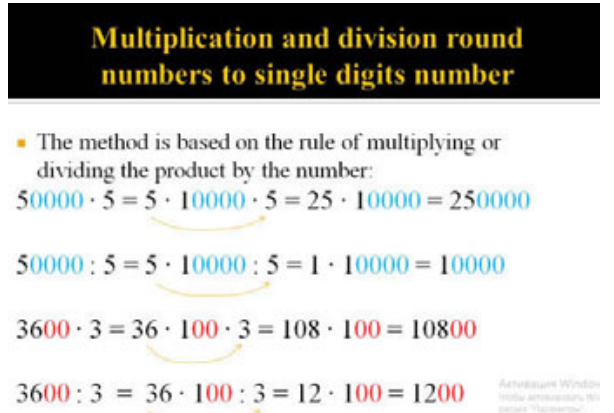

Figure 9. Fragment of the lecture on the topic "Methodology of teaching numeration of the multiplate numbers."

S o u r c e : Own work.

\section{Visual aids and didactic material}

- Set of geometric shapes of different colors and sizes: triangles,

quadrangles (including squares):

circles;

pentagons.

- cubes.

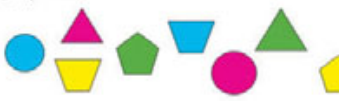

In the demonstration and distributing versions.

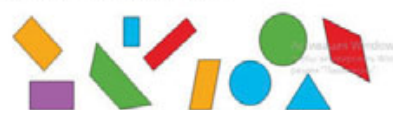

Figure 10. Fragment of the lecture on the topic "Methodology of actualization of first-grade pupils' knowledge at the beginning of the school year."

S our c e : Own work.

Some scholars (Luzghina, Tokarieva) consider the principle of multilevel font-colour marking as the most appropriate way of highlighting the text, which makes the content of the slide conventional. Thus, during the lecture the audience is taught to respond to a certain colour and font as markers of typological series, for example, a certain colour means the definition of concepts, another colour means the keywords of the text, etc. (Luzghina \& Tokarieva, 2007). According to the content of "Methodology of teaching mathematics," which to a lesser extent involves consideration of definitions of concepts but mainly presents significant features of methodological approaches, we consider it appropriate to use, apart from highlighting of information in colour and font, its presentation with the help of "SmartArt" graphic elements. Thus the same type of information (for example, the theoretical basis of the calculation methods) can be depicted in the form of the same "SmartArt" objects, which will help not only to submit the material in the structured form, but also to provide "recognition" by students of known structural elements (Figure 11). In addition, this way of presenting information will make it easier for them to perceive and memorise. It is known that familiar information is easier for memorising. In addition, psychologists note that the memory and reproduction of verbal material can be more successful if it is mediated, that is, basic points are created for that: the image of objects, charts, tables, means of visualisation. 

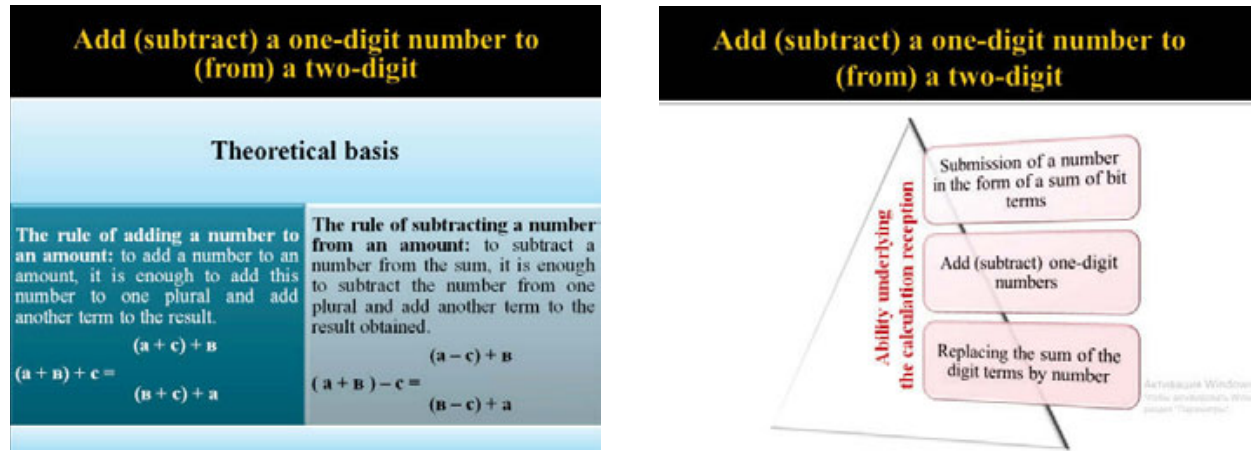

Figure 11. Fragment of the lecture on the topic "Methodology of teaching numeration of the multiplate numbers."

S o u r c e : Own work.

It should be noted that the perception of visual images facilitates the use, within the whole presentation, of the same component compositions and general style of the presentation, which in its turn it does not require additional psychological efforts during transiting from one slide to another (Mokrohuz, 2012). In addition, compliance with the requirements for organising information inside a single slide significantly increases the effectiveness of the presentation as a whole. For example, a presentation slide should not contain more than 9 different elements (text fragments, graphic objects, etc.), as it is well-known that a person is able to hold in a short-term memory 5-9 logically unrelated objects. The spatial organisation of the slide elements is projected on the basis of the analysis of the perspective trajectory. Information objects should be placed on the slide in a such a way that minimises visual paths along the screen (the placement of the information, perceived consistently, should not cause a transference of the view more than 20 $0^{\circ}$ (Mokrohuz, 2012). Returning to gender specifics, we note that the structure of the visual analyser helps women to reach the sight of the sector at $45^{\circ}$ from all sides, unlike men, who are characterised by tunnel vision.

Scientists (Ryzhov, Kornienko, \& Demidovich, 2002) describe the following principles of creating a composite solution for the presentation of visual information which should be taken into account, in particular when creating presentations of lectures on the academic subject "Methodology of teaching mathematics": conciseness (the slide contains only the necessary elements for informing the student about the essential information, the form of information presentation corresponds to the level of awareness of students); generalisation and unification (the main forms of graphical representation of the information on the slide are enlarged, the non-essential details of objects are eliminated, their form is rationally generalised; within the whole complex of presentations, the elements that designate the same objects are unified); the emphasis is on the main semantic elements 
(changing their size, form, colour is expedient and methodically motivated); autonomy (parts of the presentation showing relatively autonomous messages are clearly separated from the other parts); structuring (each part of the presentation having a central position has a distinct structure that is easily memorised and differentiated from others); and sequence (depending on the presentation stages, certain information is presented sequentially inside the slide).

The images of perceived things and objects are the result of perception, and using various visual material contributes to creating images. As mentioned above, it is the multimedia presentation that helps clarify the content of the lecture on the academic subject "Methodology of teaching mathematics" due to using dynamic visualisation, etc. (Figures 12, 13).

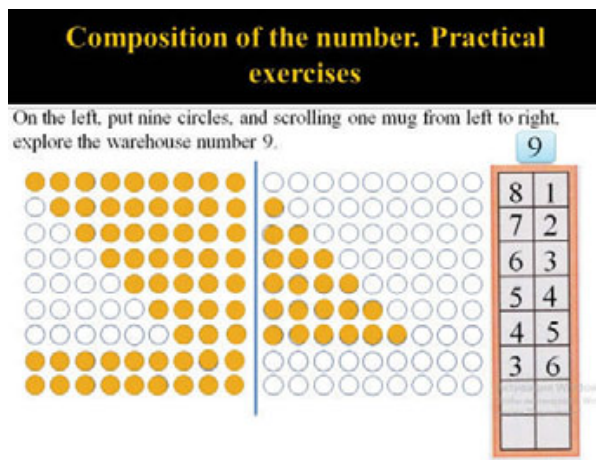

Figure 12. Fragment of the lecture on the topic "Methodology of teaching numeration of the numbers of the first dozen."

S our c e : Own work.

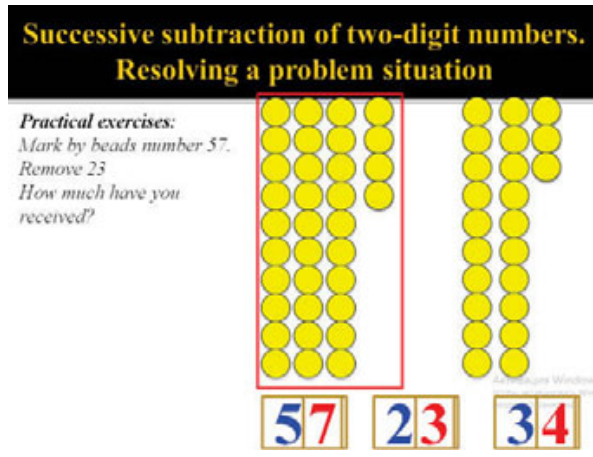

Figure 13. Fragment of the lecture on the theme "Methodology of forming calculating skills to subtract and add within 100 without transition through the class."

S o u r c e : Own work.

Perception is closely connected with the comprehension of educational information, which results in understanding the studied information and forming concepts. Psychologists state that at the stage of comprehension of the educational information it is necessary to induce students to isolate the essential elements in it, to find out the causal relationships, to compare the analysed phenomena, facts, and events.

In our opinion, successful comprehension of the educational information in "Methodology of teaching mathematics" presented in the format of a multimedia presentation will facilitate the presentation of information in the structured form with the help of tables, diagrams, charts, etc. (Figure 14), as well as using animation effects, for example, during the transfer of a known method of action to a new situation (Figure 15). 


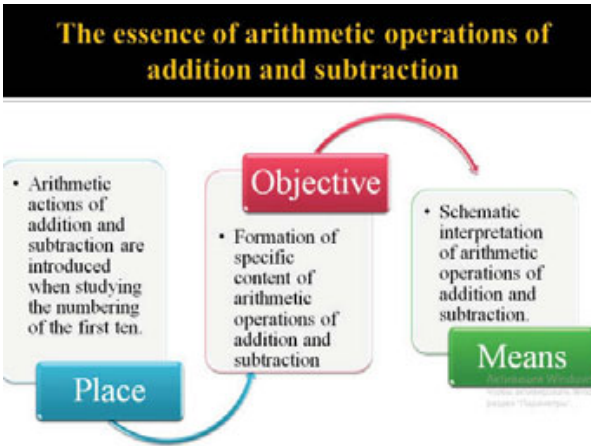

Figure 14. Fragment of the lecture on the topic "Methodology of forming calculating skills to add and subtract within 10."
COMPARE:

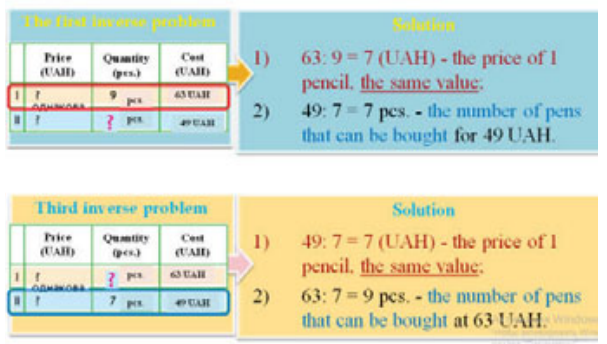

Figure 15. Fragment of the lecture on the topic "Methodology of forming skills to solve tasks in finding the fourth proportional."

S o u r e : Own work.

S o u r c e : Own work.

It should be noted that the MS PowerPoint programme allows us to apply animation effects both to objects, placed on the slide, and to the slides themselves during transition to the next slide. Such effects, on the one hand, can contribute to the aggravation of perception, but, on the other hand, they can serve as a serious obstacle for perception. Using animation should be didactically reasonable and substantiated. In this case, the effects of the transition between the slides are unjustified because they do not carry meaningful load, but are only the factors that can distract students' attention. Instead, the ability to customise the animation of slide elements is perhaps the most important advantage of using presentations in general. Applying the effects of appearance, selection, disappearance, movement of objects helps reveal the methodological aspects of the lecture. In addition, using animation effects in textual information facilitates the implementation of two-way communication and attention activisation due to the gradual appearance of text fragments, in the process when a lecturer or the students themselves comment on the material. Using animation makes it possible to submit the teaching material dosed, which optimises the perception process and at the same time structures information (Figure 16).

Sometimes, for the concentration of large volumes of illustrative material, scientists recommend using the technique of "scrolling" ("paging") of illustrations. "Paging" simulates reading the book and helps trace the deployment of the plot, the order of presentation of the material, etc. This technique was used during the inclusion of fragments of mathematics textbooks for primary school in order to analyse the order of studying the topic and comparing the methodological approaches (Figure 17). 


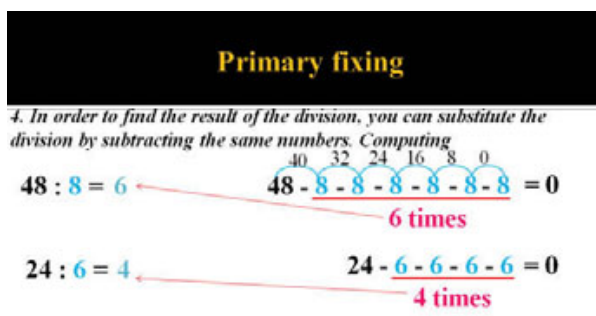

expressions in which there is a division sign between numbers is read as follows.

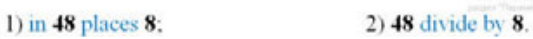

Figure 16. A fragment of the lecture on the topic "Methodology of forming calculating skills of table multiplication and division."

S ource : Own work.

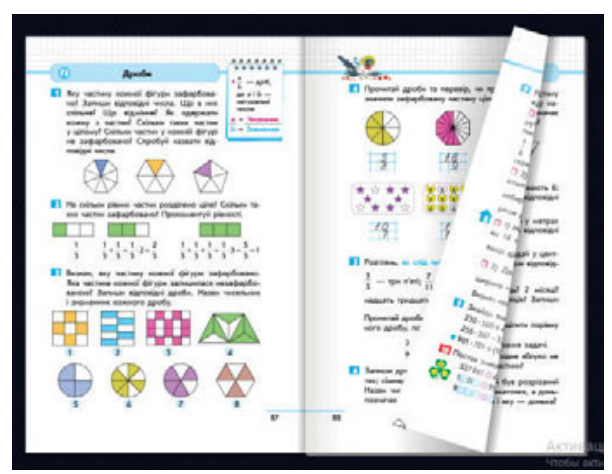

Figure 17. A fragment of the lecture on the topic "Methodology of forming the concept of a fraction."

S o u r c e : Own work.

We will concentrate on the fact that monotony must be avoided to achieve the effectiveness of learning during the lecture. It is necessary in presentations of lectures to arrange the presentation of the educational content in accordance to the change of students' activity. Thus, during the development of presentations of lectures on the methodology of teaching mathematics, it is necessary to present the content which should induce students to different types of activities.

Separate elements of the content (for example, the implementation of the methodology on the example of solving specific problems) must be presented on the slides in a consistent manner, according to the logic of presentation; others should appear immediately in the finished form. In this case, the students themselves reproduce the sequence of actions, can check the correctness of the solution by comparing their results with the result given on the slide. The task which students have to perform themselves, using the newly acquired experience, can be on the following slides. Consequently, only within the framework of mastering the method of forming a particular concept or method of action, a change in students' activity from cognition to reproduction and application can be stimulated. Such a change promotes increased attention (due to active forms of activity), awareness and comprehension of the educational material (due to the ability to recreate the acquired knowledge), and memorising (according to the pyramid of remembering, the largest part of the information is remembered during the reproduction, simulation of activity).

In order to achieve the effectiveness of the multimedia presentation of the lecture, it is advisable to take into account the described features of the basic psychological processes, which form the basis of students' cognitive activity.

Concluding, we will generalise the requirements for a multimedia lecture presentation that follows directly from the specifics of the subject "Methodology 
of teaching mathematics" and from the analysis of age-related physiological and psychological characteristics of the students of the direction of training "Primary education."

According to the general requirements for the content of the multimedia presentation, presentations of lectures on methodology of teaching mathematics should not contain large text arrays, but the theoretical information should be structured and presented in the form of charts, tables, diagrams, etc.

Requirements for the visual and sound series of multimedia presentations of lectures on methodology of teaching mathematics include using vivid colour objects, photographs, and video fragments of real mathematics lessons.

Among the requirements regarding the text given on the presentation slides of the lectures on the topic "Methodology of teaching mathematics," using the following should be mentioned: the font Times New Roman, size 36 for the headings, 24 for the main text, the dominant colour of the text is black (using other colours for the main text is allowed if it is necessary to highlight the keywords), the colour of the title text is yellow.

Requirements for the design of the presentation of lectures on methodology of teaching mathematics include: a single style of designing and same components compositions; image of the same information in the form of identical "SmartArt" elements; using black for the slide background in the header part, white for the slider working space; methodically motivated representation of the animation of slide objects, the absence of transition effects between slides.

Requirements to navigating presentations of lectures on the academic topic "Methodology of teaching mathematics" are connected with expedient and rational hyperlinks, both on separate elements of the presentation and on other objects (normative documents, textbooks, video fragments, etc.) (Skvortsova \& Haran, 2016).

Compliance with all abovementioned requirements made it possible to create high-quality multimedia presentations of lectures on methodology of teaching mathematics, capable to increase the efficiency of the educational process in view of the following facts: increasing the informativity of the lecture; stimulating learning motivation; improving visualisation of learning; intensifying students' attention through the use of animation and colour effects; accessibility in perception of information due to the parallel representation of information in various modules (visual and auditory), etc.

\section{Organisation and Results of Experimental Teaching with the Use of Presen- tations of Lectures}

The effectiveness of the introduction of multimedia presentations of lectures on the methodology of teaching mathematics in the educational process was verified in the process of methodical training of future mathematics primary school teachers 
during the formative experiment that took place during academic years 2014-2015 and 2015-2016.

In order to choose the control and experimental groups that participated in the forming experiment, in the academic year 2014-2015 an initial test of students' knowledge of the methodology of teaching mathematics was conducted.

Since subject-mathematical and didactic-psychological knowledge and skills form the basis of methodological competency, the initial test consisted of two parts, each of which contained 20 closed-ended questions to choose the correct answer, each evaluated with one score. The first part of the test was aimed at verifying didactic-psychological knowledge of students. The questions presented in this part of the test envisaged the verification of general didactic knowledge (10 questions) and were related to the normative documents of primary education, forms, methods, and teaching methods used in primary schools; verification of psychological and pedagogical knowledge of students (10 questions); and the psychological patterns of education, age, and psychological characteristics of primary school pupils, etc. The second part (20 questions) of the test aimed at testing students' knowledge of the mathematics course. This part included questions on logic, set theory, combinatorics, the theory of divisualisation, solving equations and inequalities, the basis of geometry, etc.

Testing was carried out by 325 students. They were: 84 students of the $3^{\text {rd }}$ year (PNPU named after K. Ushynsky), 70 students of the $2^{\text {nd }}$ year (KSU), 50 students of the $2^{\text {nd }}$ year (MNU named after V. Sukhomlynsky), and 121 students of the $3^{\text {rd }}$ year (UNPU named after P. Tychyna).

As a result of processing the students' responses to the test questions, the ratio of the total number of scores received by the students during the performance of the test tasks to the maximum number of points for the test (test run rate) was calculated. The generalised results of the initial test, reflecting the level of didacticpsychological and mathematical preparation of students, are shown in Table 1.

Table 1.

Generalised indicators of the level of didactic-psychological and mathematical training of students before beginning the study of methodology of teaching mathematics

\begin{tabular}{lcc}
\hline \multicolumn{1}{c}{ Name of the university } & Average score & Coefficient of the test run \\
\hline PNPU named after K. Ushynsky & 26.2 & 0.66 \\
KSU & 26.8 & 0.67 \\
MNU named after V. Sukhomlynsky & 26.4 & 0.66 \\
UNPU named after P. Tychyna & 26.0 & 0.65 \\
\hline
\end{tabular}

S ource: Own work. 
Almost equal results of the initial test were observed. Taking this into account, the students of MNU named after V. Sukhomlynsky (50 respondents) and the students of UNPU named after P. Tychyna (121 respondents) became the control group (CG). The experimental group (EG) includes students of PNPU named after K. Ushynsky (84 respondents) and students of KSU (70 respondents). Thus, the sample was 325 students: 154 in the experimental group and 171 in the control group (Haran, 2016).

In the experimental groups, during the lectures the teachers of the methodology of teaching mathematics used multimedia presentations during the formative stage of the pedagogical experiment in the educational process. Teaching methodology of teaching mathematics in control groups was traditional, without using presentation materials.

The educational subject "Methodology of teaching mathematics" provides the formation of methodological competency of future primary school teachers; therefore, the experiment was aimed at studying the influence of the developed presentations of lectures on the level of forming these personal qualities in them.

In order to determine the level of forming methodical competency of the primary school teacher in teaching mathematics, the technique of Skvortsova and Haievets (2013) was used. In the structure of every component of methodological competency (normative, variational, special-methodical, technological, designmodelling, control-evaluation), the researchers distinguish the motivational-value, cognitive, activity, and reflexive-creative components. Thus, the researchers suggest to characterise the state of formation of all components of the methodological competency of the primary school teacher in teaching mathematics to students through motivational, content, and operational-activity criteria. Effectiveness of multimedia presentations of lectures should be verified by examining the cognitive component of methodological competency precisely according to the content criterion, which characterises the degree of mastery of future teachers of methodological knowledge on teaching mathematics to primary school pupils.

The formation of the cognitive component of the methodological competency of future primary school teachers in the teaching of mathematics to pupils was characterised by the following levels:

- the low level, which is characterised by fragmentary, superficial methodological knowledge that is insufficient for the performance of professional functions;

- the average level, which is characterised by the partial possession of methodological knowledge;

- the sufficient level, which is characterised by the availability of complete, generalised knowledge of the methodology, and the ability to apply it independently in educational, cognitive, and practical-oriented situations; and

- the high level is characterised by a creative approach to teaching mathematics to primary school pupils and the ability to create innovative methodological approaches. 
In order to determine the level of formation of methodological competency of future primary school teachers, a control section was conducted according to the content criterion. Students of the control and experimental groups were offered to undergo a test on the methodology of teaching mathematics. The control section consisted of six tests, each of which foresaw determining the level of formation of normative, variational, special-methodical, technological, designmodelling, control, and evaluation components of methodological competency. Each of the tests included tasks of the closed type that contained a selection of one or several correct answers (mostly reproductive and partly productive) and open type (partially productive, productive, and creative levels). Each test contained 2 options for 5 questions.

Summarised results, obtained according to the content criterion, are presented in Table 2. The table shows the number of students of EG and CG and the levels of formation of these criteria. The distribution of students according to the levels of formation of the content criterion in the percentage is clearly represented in the diagram (Figure 18).

Table 2.

Levels of forming of the content criterion of the components of methodical competency of the students of control and experimental groups

\begin{tabular}{lcccc}
\hline \multirow{2}{*}{ Groups } & \multicolumn{3}{c}{ Distribution of the students according to the levels of forming criteria } \\
& Low & Average & Sufficient & High \\
\hline EG & 19 & 79 & 56 & 0 \\
CG & 51 & 83 & 37 & 0 \\
\hline
\end{tabular}

S ource: Own work.

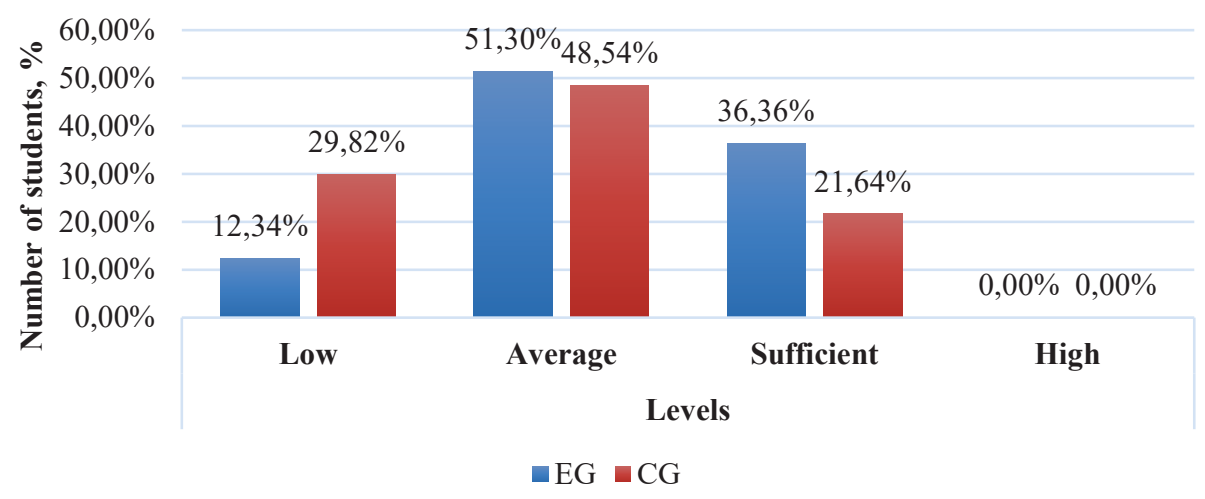

Figure 18. Distribution of students of the experimental and control groups by the levels of the formation of methodological competency.

S o u r c e : Own work. 
The Pearson criterion is used to substantiate the differences in student distributions statistically. As a result of the calculations, the value of $\chi_{\exp }^{2}=17.77$ was obtained, while $\chi_{\text {cont }}^{2}=5.99$. Hence, $\chi_{\text {exp }}^{2}>\chi_{\text {cont }}^{2}$, it shows that the differences in the distribution of respondents in the control and experimental samples are statistically significant.

Consequently, the analysis of the study leads to the conclusion that the use of multimedia presentations - developed in accordance with the abovementioned requirements of the methodology of teaching mathematics, which became the basis of experimental training - gives significantly higher results than traditional training.

\section{Conclusion}

Application of information technologies, in particular multimedia presentations, is one of the ways to increase the efficiency of lectures. Teaching with the use of a presentation stimulates cognitive and creative activity of students, and helps them master the teaching material better.

During a survey of teachers from 18 universities in Ukraine, we stated that there was a need for creating and using presentations in the course of teaching the course "Methodology of teaching mathematics" for future teachers of primary school. The research revealed the need to develop multimedia presentations to lectures in which: the educational content is given in a structured form; methodical approaches are illustrated with the use of colour and animation effects; the method of work on certain mathematical problems is given by means of dynamic deployment of the solution; natural visuality is replaced by the electronic one, and the method of working with it is demonstrated with animation effects; hyperlinks to electronic versions of normative documents and textbooks of mathematics for primary school, to video footage of real mathematics lessons in primary school illustrating an appropriate element of educational content (structure of a lesson, teaching technology, etc.), as well as video footage with students' reflections demonstrating ways of calculating, work on tasks, etc. are present. We call such a presentation a multimedia presentation of a lecture on the topic "Methodology of teaching mathematics," which its teacher can use during the entire training session and manage it interactively.

In order to create a multimedia presentation that is an effective means of teaching students, we have analysed the characteristics of the course of cognitive processes of 19-21-year-olds. Based on the specifics of the course "Methodology of teaching mathematics" and based on the characteristics of perception, comprehension, and memorisation of educational information by future students, primary school teachers formulated the requirements concerning content, visual, and sound series, 
the preparation of the text presented on the slides of the presentation, design and navigation. Since the very form of presentation of educational information and its visual design affects the quality of perception, comprehension, and memorisation of material, and optimises the absorption of the content of the lecture, presentation slides should not contain large text arrays, while the theoretical information should be structured and presented in the form of circuits, tables, diagrams, etc. Moreover, the presentation should contain bright colour objects, photographs, and video clips of real mathematics lessons. For text slices of presentations, the font, font size of the headings and main text, the dominant header colours and the main text are defined. Design of presentations should include a single style of design and identical compositions of components; images of the same type of information must be presented in the form of identical elements of "SmartArt," as well as the use of animation should be methodically motivated, and there should be no transition effects between slides.

Compliance with the above requirements makes it possible to create highquality presentations of lectures, which, in turn, allow to increase the efficiency of the educational process, namely: to increase transmission of information and to improve the presentation of the content of the lecture; to stimulate students' motivation to study the course; to intensify their cognitive activity; to focus and keep students' attention; to facilitate their understanding and memorisation of the content through its submission in a structured form using animation and colour effects, and the parallel presentation of information in various modules (visual and auditory), etc.

The results obtained convincingly prove the efficiency of the use of information technologies - in particular in the form of presentations - during the preparation of future primary school teachers for the study of mathematics, compared with the traditional one.

\section{References}

Andrievska, V. \& Olefirenko, N. (2010). Mul'timedijnì tehnologiï u počatkovìj lancì osvìti /Multimedia technologies in the elementary level of education/ (in Ukrainian). İnformacijnì tehnologiï i zasobi navčannâ /Information Technologies and Teaching Aids/, 2, 6-12.

Erofeeva, N. (2012). Osnovy gendernoj pedagogiki /Fundamentals of gender pedagogy/ (in Russian). Textbook. Izhevsk: Udmurt University Publishing House.

Gerasimchuk, B. (2004). Rekomendacï ŝodo stvorennâ ì provedennâ slajd-lekcì /Recommendations for creating and conducting slide lectures/ (in Ukrainian). Lutsk: LSTU.

Haran, M. (2016). Perevìrka efektivnostì vikoristannâ mul'timedìjnogo metodičnogo kompleksu u procesì metodičnoï pìdgotovki majbutnìh učitelìv počatkovih klasìv do navčannâ matematiki /Checking the effectiveness of the use of multimedia methodical complex in the process of 
methodical preparation of future primary school teachers to mathematics training/ (in Ukrainian). In: Pedagogika ta psihologîa: sučasnij stan rozvitku naukovih doslidžen’ ta perspektivi / Pedagogy and psychology: the current state of development of scientific research and prospects/ (pp. 43-47). Zaporizhzhia: KPU.

Khripkova, A., Antropova, M., \& Farber, D. (1990). Vozrastnaâ fiziologiâ i škol'naâ gigiena /Age physiology and school hygiene/ (in Russian). Učeb. posobie [dlâ studentov ped. in-tov] / textbook, manual (for students ped. Inst.). Moskva: Enlightenment.

Kon, I. (2006). Meždisciplinarnye issledovaniâ. Sociologiâ. Psihologiâ. Seksologiâ. Antropologiâ /Interdisciplinary studies. Sociology. Psychology. Sexology. Anthropology/ (in Russian). Rostovon-Don: Phoenix.

Lin, L., Leh, A., Kim, J. H. Y., \& Baylen, D. M. Leveraging the design and development of multimedia presentations for learners. Accessed 5 February 2018. Retrieved from https://www .igi-global.com/chapter/leveraging-the-design-and-development-of-multimedia-presentationsfor-learners $/ 189530$ ?camid $=4 \mathrm{v} 1$.

Luzghina, A. \& Tokarieva, H. (2007). Struktura kontenta medialekcii /Content structure of media collection/ (in Russian). Accessed 5 February 2018. Retrieved from http://conf.evarussia.ru /eva2007/eng/reports/content_1092.html.

Meixner, B. (2017). Hypervideos and interactive multimedia presentations. Journal ACM Computing Surveys, 50(1), article no. 9.

Mokrohuz, O. (2012). Do pitannâ ergonomičnostì mul'timedijnoï prezentacii âk faktoru iii efektivnostì /The issue of ergonomics of a multimedia presentation as a factor in its effectiveness/ (in

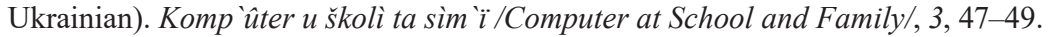

Morse, N. (2012). Proektuvannâ, stvorennâ ta vikoristannâ navčal'nih mul'timedijnih prezentacìj âk rozvitku mislennâ učnìv/Designing, creating and using educational multimedia presentations as students' thinking development/ (in Ukrainian). Accessed 5 February 2018. Retrieved from http://www.nbuv.gov.ua/ejournals/ITZN/em2/content/07dnpsts.html.

Piaget, J. (2001). Teoriâ, èksperimenty, diskussiâ /Theory, experiments, discussion/(in Russian). Moskva: Ed. Academics.

Ryzhenko, S. (2009). Pro dosvìd vikoristannâ mul'timedijnih tehnologìj u navčal'nomu procesì ( $\mathrm{u}$ VNZ) /About the experience of using multimedia technologies in the educational process (in higher education institutions/ (in Ukrainian). Accessed 5 February 2018. Retrieved from http:// www.ime.edu-ua.net/em11/content/09rssseh.htm.

Ryzhov, V., Kornienko, A., \& Demidovich, D. (2002). Kačestvo èkrannyh izobraženij v obučaûsiih programmah /The quality of screen images in training programs/ (in Russian). Pedagogičeskâ̂ informatika/Pedagogical Informatics/, 1, 42-55.

Skafa, O. \& Tutova, O. (2013). Evristične navčannâ matematiki: komp ûterno-oriêntovanì uroki /Heuristic teaching of mathematics: computer-oriented lessons/(in Ukrainian). Teaching manual: $2^{\text {nd }}$ edition. Donetsk: DonNU.

Skvortsova, S. \& Haievets, Y. (2013). Pidgotovka majbutnih učitelìv počatkovih klasiv do navčannâ molodših školârìv rozv 'âzuvati sûžetnì matematičnì zadači /Future primary school teachers' training for teaching primary school students to solve narrative mathematical problems/ (in Ukrainian). Monograph. Kharkiv: Ranok-NT.

Skvortsova, S. \& Haran, M. (2016). Vrahuvannâ psiho-fìzìologìcnih osoblivostej studentìv âk vimogado podannâ navčal'noï ìnformaciï u prezentaciâh lekcì /The consideration of psychophysiological peculiarities of students as a requirement for presentation of educational information in presentations of lectures/ (in Ukrainian). In: Social and economic priorities in the context of sustainable development (pp. 371-377). Monograph. Opole: The Academy of Management and Administration in Opole. 
Smyrnova-Trybulska, E., Ogrodzka-Mazur, E., Szafrańska-Gajdzica, A., Drlík, M., Cápay, M., Tomanová, J., Švec, P., Morze, N., Makhachashvili, R., Romanyukha, M., Nakazny, M., Sorokina, L., Issa, Tomayess, \& Issa, Theodora. (2016). Recommended applications for making presentations and didactic videos. Some research results. In M. Turčáni, Z. Balogh, M. Munk, \& L. Benko, Proceedings from DIVAI 2016 - The $11^{\text {th }}$ International Scientific Conference on Distance Learning in Applied Informatics (pp. 235-246). Accessed 5 February 2018. Retrieved from http://elibrary.kubg.edu.ua/18713/1/R_Makhachashvili_Mkonf_05_2016_GI.pdf.

Smyrnova-Trybulska, E., Ogrodzka-Mazur, E., Szafrańska-Gajdzica, A., Morze, N., Makhachashvili, R., Drlík, M., Cápay, M., Tomanová, J., Švec, P., Issa, Tomayess, Issa, Theodora, Romanyukha, M., Nakazny, M., \& Sorokina, L. (2015). Discussion paper on more adequate and effective IT tools. Some previous results concerning more adequate and effective IT tools in the category: tools for making presentations. International Journal of Research in E-learning, 1(1), 77-96.

Tkach, Yu. (2011). Okremì osoblivostì stvorennâ mul'timedìnih prezentacìj/Some features of creating multimedia presentations/. Accessed 5 February 2018. Retrieved from http://ir.stu.cn.ua /bitstream/handle/123456789/5929/Article_Multimedia.pdf?sequence=1\&isAllowed=y.

Viun, V., Huz, I., Shyshlakov, M., \& Demydenko, A. (2012) Mul'timedìa tehnologï v pìslâdiplomnìj osvìtì /Multimedia technologies in postgraduate education/ (in Ukrainian). In: Materiali XXXIX navčal'no-metodičnoï konferenciï «Cučasnij stan ta perspektivi pìdgotovki likarìv-ìnternìv u harkìv'komu nacional'nomu medičnomu universitetì, 11 kvitnâ 2012 r. /Modern condition and prospects of training intern doctors in Kharkiv National Medical University/ (pp. 21-24). Kharkiv: Kharkiv National Medical University.

Svetlana Skvortsova, Maryna Haran

\title{
Multimedialna prezentacja wykładu jako środek postrzegania, rozumienia oraz zapamiętywania informacji edukacyjnej przez uczniów
}

\author{
Streszczenie
}

Istniejący na ukraińskich uniwersytetach wymóg tworzenia prezentacji multimedialnych wykładów oraz ich użycia w procesie nauczania kursu „Metodologia nauczania matematyki” został sformułowany na podstawie wyników badań eksperymentalnych. W oparciu o cechy szczególne dyscypliny i specyficzne prawa rządzące postrzeganiem, zrozumieniem oraz zapamiętywaniem informacji edukacyjnej przez uczniów, zostały określone wymagania dotyczące wizualnej i dźwiękowej zawartości, a także tekstu zamieszczonego na slajdach prezentacji oraz projektu i sposobu poruszania się po prezentacji. Efektywność zastosowania tych praw została dowiedziona eksperymentalnie. Ustalono, że aby ułatwić postrzeganie informacji przez studentów, slajdy prezentacji nie powinny zawierać dużego obszaru tekstu, tekst powinien być napisany odpowiednią czcionką, odpowiedniej wielkości, nagłówki oraz tekst główny powinny być w kolorach podstawowych. Aby ułatwić zrozumienie i zapamiętywanie tekstu, prezentowanej informacji teoretycznej powinno nadać się strukturę schematów kołowych, tabel, diagramów, itd.. Aby pobudzić zainteresowanie uczeniem się, należy wywołać pozytywne emocje poprzez wykorzystanie rysunków obiektów wykonanych w jasnych kolorach, fotografii oraz filmów wspierających lekcje matematyki. Podkreślono, że w celu stworzenia sprzyjających warunków do postrzegania, zrozumienia i zapamiętywania informacji, projekt prezentacji powinien wykorzystać jeden styl oraz identyczne kompozycje elementów, na przykład przedstawienie tego samego typu informacji za pomocą identycznych elementów schematów „SmartArt”. 
S łow a kluc zow e: szkolenie nauczycieli, metodologia nauczania matematyki, wykład, prezentacja multimedialna

Svetlana Skvortsova, Maryna Haran

\title{
Мультимедийная презентация к лекции как средство восприятия, понимания и запоминания учебной информации студентами
}

\author{
Анно т ация
}

В результате проведенного эксперимента была выявлена необходимость создания мультимедийных презентаций к лекциям и их использования в процессе преподавания курса «Методика преподавания математики» педагогами украинских вузов. Экспериментально доказана эффективность таких презентаций. Эффективность основана на специфике дисциплины, особенностях восприятия, понимания и запоминания учебной информации учащимися, требования к содержанию, к визуальным и звуковым материалам, к тексту, представленному на слайдах презентации, к дизайну и навигации. В частности, для облегчения восприятия учащимися образовательной информации было установлено, что слайды презентации не должны содержать больших текстовых массивов; текстовые фрагменты презентаций должны быть выполнены с использованием определенного шрифта, доминирующими цветами заголовков и основного текста. Для облегчения понимания и запоминания содержания обучения теоретическая информация в них должна быть структурирована и представлена в виде схем, таблиц, диаграмм и т. д. Чтобы стимулировать интерес к обучению, создавать позитивный эмоциональный фон, презентация должна содержать яркие цветные объекты, фотографии, видеоматериалы реальных уроков математики. Подчеркивается, что для создания условий восприятия, понимания и запоминания образовательной информации, дизайн презентации должен предусматривать единый стиль оформления и идентичные композиции компонентов; изображение однотипной информации - в виде схожих элементов «SmartArt».

К л ю ч е в ы е с л о в а: подготовка учителей, методика преподавания математики, лекции, мультимедийная презентация

Svetlana Skvortsova, Maryna Haran

\section{La presentación multimedia de una lección magistral como medio de percepción, comprensión y memorización de la información educativa por estudiantes}

\author{
Resumen
}

La demanda de los profesores de las universidades ucranianas de crear presentaciones multimedia de sus lecciones magistrales y usarlas en en el proceso de impartir el curso "Metodología de la enseñanza de las matemáticas" es el resultado de la presente investigación. Desde las especifidades de la disciplina y teniendo en cuenta las peculiaridades de la percepción, comprensión y memorización de la información educativa por parte de los estudiantes, se determinan y se contrastan experimentalmente los requisitos de contenido, las series visuales y sonoras, el texto presentado en las diapositivas 
de presentación, el diseño y la navegación. En particular, para facilitar la percepción de los estudiantes de la información educativa, se ha establecido que las diapositivas de una presentación no deben contener matrices de texto grandes; los segmentos de texto de las presentaciones deben ejecutarse utilizando una fuente determinada, con un tamaño de fuente y colores dominantes de los encabezados y el texto principal; Para facilitar la comprensión y la memorización del contenido de la enseñanza, la información teórica en ellos debe estructurarse y presentarse en forma de circuitos, tablas, diagramas, etc. Para estimular el interés en el aprendizaje, la creación de un fondo emocional positivo para la presentación de la presentación debe contener objetos de colores brillantes, fotografías, secuencias de video de lecciones de matemáticas reales. A fin de crear las condiciones para la percepción, comprensión y memorización de la información educativa, se enfatiza que el diseño de la presentación debe proporcionar un estilo único de diseño y composiciones idénticas de los componentes; Imagen del mismo tipo de información, en forma de elementos idénticos de "SmartArt".

P a labras clave: formación docente, metodología de la enseñanza de las matemáticas, clases, presentación multimedia 



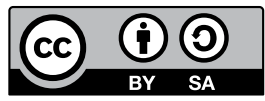

DOI 10.31261/IJREL.2018.4.2.07

\author{
Natalia Maria Ruman
}

Poland (ORCID: 0000-0002-7127-7651)

\title{
The Role of Ecological Education and IT Education in Promoting Sustainable Development of a Human Being
}

\begin{abstract}
We live in times dominated by the media, which have an impact on virtually every sphere of our lives. Nowadays, it is difficult to imagine school education without the use of modern technologies such as computers or the Internet. In the context of the ecological crisis and a number of threats associated with it which are brought by contemporary civilisation, including those of conformism or materialism, it is necessary to present a series of actions taken in education to help children and their parents oppose contemporary threats. The Internet today is becoming a good tool for exploiting information.

The article contains theoretical considerations on the important problems of modern civilisation and human education, namely issues related to ecology, the use of modern technologies, and communication. It focuses the reader's attention on important values in education for sustainable development.

Today's youth desperately need help, hence the concept of an education model for sustainable development is extremely timely, needed, and desirable. It is defined as the process of patiently building the student's interior world by passing on values that are cultural achievements.

Only in culture can a human live a truly human life. We strive for the truth because we want to create a community, and it is the interactivity that gives us the chance to participate and implement the community. Despite the pessimistic picture that a human will give in to the machine, we can come to the conclusion that the Internet gives the environment the possibility of integrating societies. It is
\end{abstract}


a tool, but not a guarantee, and if we recognise the Internet well, there may be hope for us.

K e y w o r d s: Internet, sustainable development, youth, ecology, education

\section{Introduction}

One of the most important problems of the modern world is the protection of the natural environment. Initially living in connection with nature, the human began to transform it along with the development of science and technology. Because of the ongoing degradation of nature, in the second half of the twentieth century comprehensive actions were taken to protect the environment. Thus, it indirectly contributed to the protection of human beings.

The basis of this activity should be the education of the general public, starting from the youngest generation, which does not mean the postponement of IT activity.

\section{Ecological Education Issues - Reflections}

The text contains theoretical considerations on the role of ecological education and ICT (Information and Communication Technologies) in promoting sustainable human development. The aim is to present a series of actions taken in education to help children and their parents counter contemporary threats to sustainable human development. As factors contradicting the threats to human development, we will consider ecological education and the use of new technologies.

Also, educators need to improve and broaden the skills of creating animations or websites rich in graphics and special effects, and thus to actively use information technology in their professional work. Developing habits of respecting culture in the processes of global information exchange is also an important task for educators. This article is intended to arouse readers' reflection on the subject.

Applying incentives to the school community to make use of the potential inherent in culture is a condition for education for sustainable development. The level of cultural competence is the key value determining the position of the individual in his or her environment. The ability to broaden and share knowledge, the ability to use technological achievements, and the ability to take risks and develop their "singularities" - these are just some of the features a modern school community should have. These are the features that also define the direction of 
development and determine the competitiveness and innovation of education for sustainable development.

Educational values are of great importance in environmental education, which serves primarily to shape the attitude of respect towards all life, the ability to use resources moderately, and the sense of responsibility for the environment in which we live.

In education for sustainable development, the concept of needs should be attentive to the necessity of a holistic and holographic approach, pointing to the difference between Happiness and "happiness." Happiness is defined in classical meaning, according to the Aristotelian approach, while "happiness" is defined as a transient emotional state. Understood in this way, "happiness" does not guarantee constant contentment, but only generates needs and a desire to constantly meet ever new needs.

The term "social ecosystem," in a sense, touches on the serious problem of opposing culture to nature while showing a way to overcome this opposition. Regional education is of key importance here. It helps get to know the closest surroundings, understand the local tradition, and, as a result, create a bond that will foster positive references to the environment.

The idea of involvement in environmental problems by shaping respect for regional traditions and culture is called bioregionalism. It depends on individual involvement in environmental issues, which is possible thanks to identification with a given place. The beginning of a kind of relationship with the bioregion is getting to know it by asking questions that open up to local problems and allow to better understand the neighbourhood. Incorporating bioregionalism into ecological education helps build ties with people, culture, and place, teaches love and respect for the near and distant nature, and teaches responsibility for the environment. By "taking root" in a bioregion, one can communicate one's attitude of respect and responsibility for nature much more effectively.

An important reinforcement for raising ecological awareness is a religious reference. That includes conducting a philosophical discussion on the references of religion to the natural environment. Nature should also be seen through the prism of values: it should be perceived as a value and presented as such to pupils and students.

Culture and upbringing are closely interdependent; as John Paul II pointed out, in upbringing it is important to pay attention to the fact that a human being, through what he or she has, knows how to be more human. Values such as freedom against material goods, justice, and love should make it possible for a student to become a human in the full sense of the word, and not only to serve the better in the world.

From the documents containing the teaching of the Church on ecology emerges a specific concept of integral ecology, combining environmental protection with human ecology. It results from theological, philosophical (anthropological), and social assumptions. John Paull II treats man and his environment as a certain 
unity - the ecological universe, whose threat requires protection and defence. He points out the need for actions aimed at shaping the moral obligations of a man towards the world of nature, himself, and other people. John Paul II devoted a lot of attention to environmental issues; he taught: "It seems that what threatens the creation and man most is the lack of respect for the laws of nature and the loss of the sense of the value of life. [...] The beauty of this land makes me cry for its preservation for future generations. [...] [I]n the family and at school one cannot lack education to respect for life, for good and beauty. All people of good will should cooperate in this great work." The Pope also points to the need for an "ecological conversion." "Therefore, it is not only the "physical' ecology striving to protect the environment, but also the 'human' ecology, which would make the existence of all creatures more worthy, caring for the basic good of life in all its manifestations, preparing for all generations an environment that more he will come closer to the plan of the Creator" (John Paul II, 2001, quoted in: Tyburski, Wachowiak, \& Wiśniewski, 2002, pp. 462-463).

A religion that is genuinely understood and practiced not only stimulates one to fulfil the ritual, but also arouses, among other things, a sense of sacrality of creation and moral responsibility for the state of the environment (Langiewicz, 2002, p. 530). The Church observes that "[...] disregarding or rejection of basic ethical norms leads man to the threshold of self-destruction" (John Paul II, Message for the Day of Peace, 1 January 1999). Many processes can still be mastered; it is a task for all of us and it is especially important in setting up educational programmes for children and young people at school. People are supposed to rule the Earth with wisdom and love. Ecology is a natural reflex of gratitude to God for His gesture of giving: "the depths of the earth are in His hand and the peaks of the mountains belong to Him" (PS 95.4n) (Michalik, 2002, p. 447).

Attention should be paid to the need to personalise the issue of environmental ethics; this approach shows the need to show respect for living creatures in proportion to their existence. The personality approach to environmental ethics is based on the principle of love, understood as striving for good. An important role is played by the concept of metanoia, which involves a significant internal spiritual change, in the context of upbringing to respect the environment, which leads to treating the ecosystem as a home that prepares one for a wise existence in the world, for realising the truth in life, beautiful and good.

A human's justice towards creation can be treated as a feedback in the cybernetic theory of feedback. It impacts in the human-ecosystem relationship. The more we strive for justice in our impact on the ecosystem, the more we derive benefits from it, and we become more and more positive in the work of the Creator. Our land does not belong to us - we are only visitors and settlers here. In society, education not only in the legislative area, but also in environmental matters is required. Considering the problem of education in the age of threats to the social and natural 
environment, attention should be paid to the role of personalism in upbringing as a tool to overcome the ecological crisis (Bławat, 1995, pp. 41-43).

The philosophy of dialogue can be a plane on which some of the problems of pedagogy can be solved by introducing an openness to the other, making the relation with the second guarantor of the axiological reference. In the philosophy of dialogue, the paradigm of struggle and war is replaced by the obligation of rapprochement, openness, kindness; it breaks with the desire to be "someone" in favour of being "for" the other. It is the basis for undertaking activities for the other.

It should be concluded that the environment in which people currently exist consists of natural components, but also of virtual spaces that are possible due to new technologies. Such technologies create both threats and stimuli for human development, especially for interpersonal communication. Humanity in its technologically and institutionally developed areas (states, societies) has entered a new era of global information and telecommunications, the era of information and the information (network) society. The development of information and communication technologies is a key element of contemporary civilisational transformations and the creation of an information society (Siemieniecki, 2007, p. 37). The contemporary world, especially the closest environment, has an increasingly electronic and virtual dimension. Tools such as the Internet, a computer, a multimedia telephone, electronic data carriers, management and support programmes are common not only among employees, but also (and perhaps above all) among children and young people.

Nowadays, new technologies play a crucial role in the lives of young people, constituting a learning, communication, and entertainment environment. Tamara Ericsson describes this phenomenon as a total immersion in technology (Pugacewicz, 2009, p. 528).

For young people, the Internet is the basic source of information used in the process of satisfying the information needs related to the school education process. There is a need to prepare students for:

- efficient use of ICT tools in the processes of downloading, merging, and improving information;

- creating a presentation in a form that suits the needs of the recipients and corresponds with the content of the information message, without affecting the reduction of its quality;

- effective use of various sources of information and ICT tools in the process of exchanging and presenting various messages;

- finding ways to use various ICT tools in the process of providing information, e.g. such methods as using e-mail, organising videoconferences, or publishing content on the Internet; and

- most of all, the ability to critically evaluate the use of new media (Przelaskowski, 2011, p. 33). 
There is a lack of implementation of digital and interactive teaching materials tailored to students' needs and communicating information about the progress in real time. This system is ineffective in the form of its functioning because it uses the access to the global knowledge base like the Internet to a very small extent (Hamala, 2013, pp. 81-94).

\section{Media in Education for Sustainable Development}

We live in times dominated by the media, which have an impact on virtually every sphere of our lives. The Internet is a dynamically developing tool and a space of knowledge. It is postulated to develop a strategy for schools in the field of teaching children the correct use of Internet sources. We should develop the students' abilities to critically use the computer and multimedia, wisely move around in the maze of information, and use multimedia knowledge on the principle of analytical selection. Nowadays, information technologies are closely connected with the concept of multimedia education. They are identified with the methods and techniques of communication in the field of creating, storing, selecting, transmitting, and sharing information (https://docplayer.pl/96205130-Mariusz-Z -jedrzejko-technologie-cyfrowe-a-rozwoj-edukacyjny-i-emocjonalny-pobudznieagresja-dzieci-nastolatkow.html, accessed 3 August 2017). Nowadays, it is difficult to imagine school without the use of modern technologies such as computers or the Internet. The preparation of educators who are constantly learning at the technology level is the future of education. Advanced information and communication technologies enable the creation of interactive multimedia materials for the needs of education. The implementation of modern ICT technologies into educational practice is becoming a necessity. However, this requires a wider reflection because there are doubts whether this initiative will bring the expected results, especially since it is not at all encapsulated in "education for computerisation and cyberspace."

The definition of new media was presented for the first time in Western Europe, and it reads as follows: "New media and telecommunications, in particular multimedia, mean media (with texts, images and sounds) and information and communication techniques that allow the use of digital recording and algorithmic processing techniques to process and transmit arbitrarily large amounts of data in the shortest time." Based on this definition, the new possibilities offered by media use are presented:

a) the ability to access large amounts of data for space and time for processing;

b) establishing an interactive relationship between any remote computer systems;

c) various applications, both in local and external networks; and 
d) creating virtual reality connected with real presentations in an indistinguishable way (http://sjp.pwn.pl/slownik/2567152/mass_media, accessed 7 November 2017).

The world is evolving, but have we seen the world well? Where is the sense of a human being if the Internet enforces a certain lifestyle? The new media is a kind of interactivity; it works integrally because it gives the chance to integrate society.

The information society is the next stage of humanity, just like once a certain stage was, for example, hunting society. Nowadays, the society is oriented to the exploitation of information.

We once said that the human environment is nature; then we came to the conclusion that it was people, or society. Later Pope Francis wrote about it in the Encyclical Laudato si, and that the human environment is nature and society. If the environment is recognised as something that affects our identity, a space that allows us to live and be ourselves, the Internet is characterised by a society that is ageographic, i.e. independent of where we are.

However, it should be emphasised that it is neither a network society nor a knowledge society, but a society of information. Our society is the one that builds relationships in it. Helpful in maintaining identity, creating our natural environment is an infocomponent. This is called "4P" (from the statement of prof. Michat Wyrostkiewicz (KUL) on interactivity as a tool for integrating the information society, presented at a scientific conference on WTL, UŚ, 19 June 2018) - it is the acquisition, processing, transmission, and storage of information. And this is happening in the information society as a basic thing.

Information technology has also caused changes in pedagogy, which is why the components set by Scott Kelby are:

- student - a passive recipient turned into an active learner;

- the subject of learning for the task taught, in which educational goals and initial knowledge of the information technology of the learner have been taken into account;

- from the teacher to the learning environment, which may include new media (video, computer, etc.);

- scope and level of education, which means systemic treatment of the education process. In addition to positive effects, we face problems that result in risks and disruptions in understanding the content transmitted. The first of them is media addiction, often referred to as cyberholism or infoholism, the second the flattening of knowledge. One can assume that students who use unlimited cyberspace may be exposed to them (Perzycka, 2008, pp. 73-75).

The biggest shock for humanity would be the problem of a sudden lack of media. The reaction to the action as well as the possibility of changing the role of information exploitation is the tool of integration of society, or interactivity. In it everyone seeks the truth, thanks to it we are not just passive recipients. Rarely meeting peers face-to-face after school, the child wants to continue to speak. 
The Internet comes to help. Reading a post (that is, practically one sentence), we comment on them and microblogs are created. We can be the sender at any moment. Even our likes - it is our reaction, it is our voice consent or not. However, it should be remembered that not every communication of information is a real communication, that is, communio. It is necessary to recognise the need for a model of upbringing which would be an integral education, taking into account the material and spiritual dimension of the human being, in which the human person is treated as the goal of all action, and science and technology are the means of human development, the way to deepen his humanity and interpersonal relationships (Świerszcz, 2007, pp. 15-16).

Without an intellectual and moral order, there is no order in action (Mizińska, 1993, p. 153-165). The ability to choose good and "voluntary" activities should be taught. Moral freedom, understood as obedience to rights dictated by one's conscience, is the absolute goal of education (Nawroczyński, 1987, p. 279). Culture from the objective side is a specific system of values, chosen and implemented in a specific way. Their creation gives meaning to human life (Ingarden, 1972, pp. 13-18).

John Paul II wrote that "There is no contradiction between obedience and freedom." The most important form of obedience is obedience to the revealed truth: in it the human freedom is expressed most fully, and without such reference to the truth freedom becomes chaotic. The Pope observed the danger of mass culture mass culture is inspired by materialism, which threatens the process of education, imposes an attitude of passive acceptance of fashion and material needs, stimulates consumption that leaves emptiness in human consciousness, and leads to escape from personal choices or freedom. John Paul II encouraged young people, at an age so important for shaping a mature personality, to learn to give the right place to the religious factor of formation, able to raise a man to full dignity. "A young man deprived of good manners is an inefficient heart that in the biblical language means a human spiritual interior, in particular means conscience [...]. So, man must be measured with the measure of conscience" (Jan Paweł II, 1997, p. 27).

The Internet, in terms of its technical capabilities and its use for various purposes, develops very dynamically. Young people (that is, children and young people), whose personality is just being formed, are particularly frequent users of modern technologies, and therefore the impact of the Internet on children and young people is of special importance.

The human personality is shaped by the interaction of three factors:

1) inborn, or genetically conditioned, hereditary biological preoccupations with which we come into the world;

2) the second element affecting a person is his or her environment, especially the social environment (e.g. family, friends);

3) own activity - activities undertaken in a free and purposeful manner. 
It is possible to develop the competence of education for sustainable development at school, when the implementation of teaching content makes students aware of how the process of economic and civilisational development affects the condition of the natural environment and the situation of human societies, directly referring to concern for future generations. All students should acquire knowledge, values, and skills in the field of civic education and relating to sustainable development, which will allow them to participate fully in social life and engage in activities to solve the problems of the modern world.

Information technology has an extremely strong impact on society; it is estimated that in the developed countries, nearly $40 \%$ of jobs are related to the IT industry. Nowadays, information has become a commodity, often considered to be much more valuable than material goods. We are entering the era of a knowledgebased economy. Therefore, we can say that we live in an information society (Noga, 2006, pp. 111-116).

Social life - human (child's) contact with other people - is manifested through communication or exchange of information. Communication can be of a different nature, and we divide it into direct communication and indirect communication. Direct communication, as the name suggests, relies on direct contact between people, which is sometimes referred to as face-to-face communication. One can also include contact made by means such as a telephone or letters sent by mail, which complement direct conversations. In such communication, the interaction is mutual; the first person's message affects the other person, and the other person's response affects the first person.

Open educational resources are didactic and scientific materials presented in digital form, with open and free access for students, lecturers, and self-tutors, who can use them for educational and research purposes. These are often very valuable didactic materials. Open educational resources are a kind of electronic public library that facilitates learning, studying, and gaining knowledge. The most commonly used teaching materials posted on the Internet are:

- recordings of lectures: audio and video;

- lectures in text form;

- multimedia manuals;

- archives of publications, photos;

- data settings; and

- computer software.

Contemporary changes in media and information technologies lead to a new approach to the concept of competence education in this area. Despite the difficulties and definition disputes, the concepts of media and information competences - so far separated - should be treated as a whole, pointing to different approaches to the same communication reality. Digital media are defined forms of multimedia content use, such as the Internet, digital television, mobile telephony, electronic mail, DVD distributions, etc. Remote availability through telecommunications networks, 
which results in the need to normalise the ways of data representation and their descriptions (metadata) is a condition for effective exchange of information. Maria Próchnicka stresses the need to acquire information competences by all members of society; she writes: "literacy is an integrated set of knowledge, skills, attitudes, awareness and values that are necessary for action in contemporary society, in all spheres of social life. Information competences are necessary not only for those members of society who participate in the activities of individual organisations, but also those who are within their reach, that is for the whole society. The necessity of being literate includes all members of society [...]" (Próchnicka, 2007, p. 442).

With the dissemination of information and communication technologies, the mere availability of equipment and the fact of use cease to differentiate. Much bigger differences are revealed between users who have appropriate competences and are able to use technology in a way that benefits and improves their life situation, and those who do not.

The reality of the digital era gives teachers higher requirements oriented to the education of information competences, in the sphere of applying new ICT trends to educational practice. The contemporary teacher is expected to undertake professional (didactic and care-educational) tasks supported by ICT methods and tools (Baron-Polańczyk, 2013, pp. 15-55).

The frequency of teachers' use of tools increases in such areas as: communication (e-mail, chat, instant messengers, e.g. Gadu-Gadu, Skype), searching for and creating information according to their own interests, and preparing for didactic classes. The reasons for using ICT are perceived as individual benefits - optimising professional tasks, including facilitations and improvements in preparing for classes, in performing lesson plans, teaching materials or tests. ICT development is important for teachers' personal and professional life as well as for educational policy and school environment in which they work (Day, 2004, p. 17).

The pace of technological development is so fast that it is difficult for the education and training system to keep up with the changes. In this context, graduates of STEAM (Science, Technology, Engineering, Arts, Math) are the most desirable on the labour market. Better adjustment of education programmes to the needs of young people and a clearer focus on literacy education seems to be the best solution to the problem of youth dissatisfaction with information education in Polish schools.

Skills related to information technologies are the motivation to develop ecological (green) skills for sustainable development in education. Sustainable development is one of the most important challenges of the modern world. It means development that meets current needs without jeopardising the ability to meet the needs of future generations. The implementation of the principles of sustainable development has an increasing impact on the labour market subject to dynamic changes in recent years. It is forecast that there will be an increase in the demand for specialists of advanced technologies, installing or servicing new devices to 
improve the environment or produce new ecological goods / services (Bernaciak, 2004, pp. 27-31). This is related to the fact that society attaches ever greater importance to the quality of the environment and its immediate surroundings. From the point of view of didactic materials, a significant barrier to developing vocational education / training offer in the area of green economy professions for sustainable development is the lack of textbooks and modern didactic materials. Education and training in green economy professions can significantly contribute to creating pro-ecological attitudes and new jobs. Activities carried out in this area should be more comprehensive and aimed at strengthening innovative behaviours involving various stakeholders - self-governments, the scientific community, vocational schools, and training institutions.

An increasingly important role in human life in the modern world is played by the second type of communication, or indirect communication. An increasing number of people use mass media. This kind of communication can also be divided into two types: mass media and mass communication. Although these names are often used interchangeably, they are in fact related to separate matters. This distinction was not needed until recently, that is, before the creation of the Internet, because only one-sided media existed at the time. The means of mass information - which can be otherwise called means of transmission or influence and include television, radio and newspapers - operate unilaterally. The recipient of content remains passive. His or her activity is limited to the decision to use (or not to use) the media offer, but he or she does not interact with them. Today's fashionable media interactivity is apparent because it is limited to a very small number of people, e.g. a dozen or so listeners calling to the radio during the broadcast received by tens of thousands of people; their statements become an element of one-sided content and constitute a particularly convenient strategy of manipulation because they create the appearance of unanimity of listeners - the "mechanism of social equity" described by social psychology is active, suggesting that since everyone is thinking and doing something, it is probably right (Karkowska, 2007, pp. 167-179).

A phenomenon that works on a large scale is mass interactive communication, in which the participant is both an active recipient and an active broadcaster. This possibility is offered by the Internet when it is used to deal with various matters, to participate in games, and to make contacts (Smyrnova-Trybulska \& Żebrok, 2015, pp. 47-69).

These contacts can be asynchronous in time (e.g. at e-mail) or synchronous allowing for direct exchange of information, just as it happens in an oral conversation. In the latter way of communication, interaction partners interact with each other (as in face-to-face contact), so it is similar to direct communication, but in many respects it is very different from it. This communication is devoid of non-verbal, visual, auditory, and tactile messages. The appearance of the interlocutor, the expression of his or her face, the rate of expression, tone of voice, mimic reactions, gestures, and similar non-verbal messages are of great importance in direct 
communication and sometimes become more important than the content of the statement. All this is lacking in communication via the Internet. On the Internet it is possible to use anonymous communication, and unfortunately users take advantage of this fact: participants do not introduce themselves, but also they may change their own identity. For example, there may be a change of gender, age, or sexual orientation (it carries a great danger for the youngest). This communication can be called interactive, but not interpersonal (Smyrnova-Trybulska, 2017, pp. 130-139).

\section{The Essence of Technological Activities}

Existence in the information society from the very definition requires appropriate information competences from the modern human. Therefore, a great emphasis is put on skills in the operation of information and the use of modern information sources, while all activities related to the conscious, effective, wise, and ethical use of digital information become important.

The reality of the digital era gives teachers more and more different requirements oriented to shaping specific areas of information competence, setting directions for professional development, including in the area of applying new ICT trends to educational practice. It is expected from a contemporary teacher that the occupational tasks (subject-didactic, and care and educational) that are undertaken are supported by ICT methods and tools. In the context of permanent general and professional development, empirical findings of conditions that construct the circumstances in which teachers choose (or fail) to use ICT in everyday life and school practice are important (Baron-Polańczyk, 2015, pp. 103-109).

Computer communication has the following advantages:

- it eliminates the limitations of time and space;

- it maintains bonds;

- it enables exchange of information, opinions, and emotional message;

- it facilitates cooperation, broadens the range of mobilisation (wider, more effective networks);

- it generates low costs.

Does the mere flow of information lead to the emergence of social capital and authentic communities?

The impact of any type of communication can be positive and negative.

Analysing the impact of media on recipients (children), we can talk about three attitudes: those of resistance, submission, and activity:

- The first is the attitude of resistance to the media - it is expressed in the fact that the recipient is not adversely affected by them and tries to critically assess the messages reaching him or her, being aware that certain content may be unreliable.

- The attitude of submission is in opposition to the attitude of resilience - it consists in the lack of criticism and in-depth reflection on the received content, 
as well as excessive credulity or even naivety during the assessment of the credibility level of the received content.

- The last attitude is that of activity - it consists in the constant tendency of the individual to positively influence the media in order to make beneficial changes in them (Braun-Gałkowska, 2003, pp. 14-20).

Media competences are necessary to develop professional competences: media pedagogy and the use of media in education. Both of these types are based on the media competences that an individual acquires during his or her life, through everyday contact with new media.

Every person shapes his or her individual media competences from birth, learning to think and deal with all kinds of media (and thanks to them). All people who are influenced by new media in modern societies acquire functional media competences.

The acquisition and implementation of competences in media pedagogy, based on the competences acquired in everyday life as well as during the profession, can be differentiated (Nowakowska-Buryła, 2003, pp. 32-33).

\section{Conclusion}

Ecological education is a process that can not end with the end of formal education; it is a process that should last a lifetime. As a result, it is possible to achieve an adequate level of social activity and a high level of environmental awareness, which in turn leads to sustainable development.

The improvement of this state of affairs is seen, among others in: theoretical and scientific reinforcement of the sustainable development strategy; implementation of the basic human right to education regardless of age and institutional affiliation; including environmental education at all levels of education, not only formal ones. Achieving the intended goal requires a combination of efforts of social educators, theoreticians, environmentalists, and didactics.

The preparation of educators who are constantly learning at the technology level is the future of education. Advanced information and communication technologies enable the creation of interactive multimedia materials for the needs of education. The implementation of modern ICT technologies into educational practice is becoming a necessity. However, this requires a wider reflection because there are doubts whether this initiative will bring the expected results, especially since it is not at all encapsulated in "education for computerisation and cyberspace" (Juszczyk, 2000, p. 51).

The media should be more involved in environmental education of the society, especially in the areas of: 
- popularisation of environmental protection programmes;

- informing the public about ecological standards and ecological law requirements;

- popularisation of new technologies (BAT), companies implementing technologies;

- helping schools, social organisations in the universal ecological education of children, youth, and adults;

- presentation of environmentally friendly attitudes, people - ecological experts, leaders of environmental protection;

- improvement of communication: media - ecological authority;

- presentation of activities of ecological education centres;

- coordinating the activities of various centres conducting ecological education (http://www.osrodekedukacjiekologicznej.pl/media-a-ochrona-srodowiska-. html, accessed 7 November 2017).

Environmental protection is becoming more and more fashionable and important. It enjoys great interest of people around the world, and thus the media.

The way of life and perception of the reality that surrounds us has changed. The revolution in modern technologies applies to every young and mature member of the community, which is why contemporary education is facing a huge challenge. The multiplicity and change of new patterns of life confront our previous educational beliefs, as well as generate the need to deconstruct the basics of thinking about the world, humanity, and the possibilities of supporting the development of the individual's identity.

\section{References}

Baron-Polańczyk, E. (2013). Reasons for the use and non-use of ICT in teachers' professional practice (in the light of own research). In: E. Baron-Polańczyk (Ed.), ICT in educational design. Processes, materials, resources, vol. 5 (pp. 15-55). Zielona Góra: Oficyna Wydawnicza Uniwersytetu Zielonogórskiego.

Baron-Polańczyk, E. (2015). Hierarchia ważności działań nauczycieli w wybranych obszarach ICT (raport z badań). Edukacja Ustawiczna Dorosłych / Polish Journal of Continuing Education, $1,103-111$.

Bernaciak, A. (2004). Ochrona środowiska w praktyce. Aspekty ekonomiczno-prawne. Poznań: SORUS.

Bławat, A. (1995). Antypedagogika. Postmodernistyczne zakwestionowanie wychowania. /Antipedagogy. Postmodern challenge to education/. In: Z. Sareło (Ed.), Postmodernizm. Wyzwanie dla chrześcijaństwa (pp. 40-51). Poznań: Pallottinum.

Braun-Gałkowska, M. (2003). Oddziaływanie Internetu na psychikę dzieci i młodzieży/Psychological impact of the Internet on children and youth/. Edukacja Medialna, 3, 13-20. 
Day, Ch. (2004). Rozwój zawodowy nauczyciela. Uczenie się przez całe życie /Professional development of the teacher. Lifelong learning/. Trans. J. Michalak. Gdańsk: GWP.

Hamala, M. (2013). Technologia informacyjna jako nowoczesne narzędzie komunikacji z otoczeniem /IT as a modern tool of communication with one's surroundings/. Spoleczeństwo i Edukacja. Międzynarodowe Studia Humanistyczne, 2, 81-94.

Ingarden, R. (1972). Książeczka o człowieku /A book about a man/. Kraków: Impuls.

Jan Paweł II. (1997). Przemówienie do młodzieży akademickiej zgromadzonej przed kościołem św. Anny /Speech to the academic youth gathered in front of the church of St. Anna/ Warszawa 03.06.1979. In: Jan Paweł II, Pielgrzymki do ojczyzny 1979, 1983, 1991, 1995, 1997. Przemówienia, homilie. Kraków: Znak.

Juszczyk, S. (2000). Człowiek w świecie elektronicznych mediów - szanse i zagrożenia (o problemach tworzacego sie spoteczeństwa informacyjnego) /Man in the world of electronic mediaopportunities and threats (about the problems of the emerging information society)/. Katowice: University of Silesia Press.

Karkowska, M. (2007). Socjologia wychowania /Sociology of education/. Łódź: Wydawnictwo Wyższej Szkoły Humanistyczno-Ekonomicznej.

Langiewicz, M. (2002). Katolicka myśl ekofilozoficzna. Ateneum Kapłańskie, 3, 517-535.

Michalik, J. (2002). Chrześcijańska odpowiedzialność za ziemię. Refleksje o ekologii /Christian responsibility for the earth. Reflections on ecology/. Ateneum Kapłańskie, 3, 443-449.

Mizińska, J. (1993). Postęp i okrucieństwo /Progress and cruelty/. In: S. Kyć (Ed.), Humanizm ekologiczny, vol. 2 (pp. 153-167). Lublin: Politechnika Lubelska.

Nawroczyński, B. (1987). Przymuszać czy wyzwalać? /To coerce or to free?/. In: B. Nawroczyński, Dzieła wybrane, vol. 1 (pp. 172-188). Warszawa: Wydawnictwo Akademickie Żak.

Noga, H. (2006). Wybrane aspekty edukacji informatycznej dzieci i młodzieży/Selected aspects of IT education for children and youth/. Technika - Informatyka - Edukacja. Teoretyczne i praktyczne podstawy edukacji informatycznej, 6, 111-116.

Nowakowska-Buryła, I. (2003). Postawy dzieci wobec mediów /Attitudes of children towards the media/. Edukacja Medialna, 1, 31-35.

Perzycka, E. (2008). Struktura i dynamika kompetencji informacyjnych nauczyciela w społeczeństwie sieciowym /Structure and dynamics of the teacher's information competences in the network society/. Szczecin: Wydawnictwo Naukowe Uniwersytetu Szczecińskiego.

Próchnicka, M. (2007). Information literacy. Nowa sztuka wyzwolona XXI wieku. /New liberated art of the $21^{\text {st }}$ century/. In: J. Dzieniawkoska (Ed.), Ksiażka, biblioteka, informacja: między podziałami a wspólnota (pp. 433-445). Kielce: Wydawnictwo Akademii Świętokrzyskiej.

Przelaskowski, A. (2011). Techniki multimedialne /Multimedia techniques/. Warszawa: PWOKNO.

Pugacewicz, I. (2009). Tamara Erickson: Plugged in. The Generation Y guide to thriving at work. Massachusetts 2008. Przeglad Biblioteczny, 4, 527-532.

Siemieniecki, B. (2007). Technologia informacyjna w polskiej edukacji /Information technology in Polish education/. Torun: Wydawnictwo A. Marszałek.

Smyrnova-Trybulska, E. \& Żebrok, P. (2015). On networking. The analysis of selected aspects. International Journal of Research in E-learning, 1(2), 47-69.

Smyrnova-Trybulska, E. (2017). Networking is one of the effectiveness from of the international research. Some aspects. Open Educational E-environment of Modern University, 3, 130-139.

Świerszcz, K. (2007). Destrukcyjność laickiego wychowania w świetle współczesnych ideologii /The destructive nature of secular upbringing in the light of contemporary ideologies/. Communio, $3,13-18$.

Tyburski, W., Wachowiak, A., \& Wiśniewski, R. (2002). Historia filozofii i etyki dla wspótczesności. $3^{\text {rd }}$ ed. Toruń: Wydawnictwo Dom Organizatora. 
Natalia Maria Ruman

\title{
Internet - w kontekście edukacji na rzecz zrównoważonego rozwoju
}

\author{
Streszczenie
}

Żyjemy w czasach zdominowanych przez media, które mają wpływ praktycznie na każdą sferę naszego życia. W obecnych czasach trudno wyobrazić sobie edukację szkolną bez wykorzystania nowoczesnych technologii, takich jak komputery czy internet. W kontekście kryzysu ekologicznego i szeregu zagrożeń z tym związanych, jakie niesie ze sobą współczesna cywilizacja, w tym między innymi zagrożeń konformizmu czy materializmu, należy przedstawić szereg działań podejmowanych w edukacji, które mają pomagać dzieciom i ich rodzicom przeciwstawiać się zagrożeniom współczesności. Internet dzisiaj staje się dobrym narzędziem do eksploatowania informacji.

Artykuł zawiera rozważania teoretyczne na temat istotnych problemów współczesnej cywilizacji i edukacji człowieka, czyli zagadnień dotyczących ekologii, wykorzystania nowoczesnych technologii i komunikacji. Autorka skupia uwagę czytelnika na ważnych wartościach w edukacji na rzecz zrównoważonego rozwoju.

Dzisiejsza młodzież bardzo potrzebuje pomocy, stąd koncepcja modelu edukacji na rzecz zrównoważonego rozwoju jest niezwykle aktualna, potrzebna i pożądana. Koncepcja ta określona jest jako proces cierpliwego budowania wnętrza wychowanka poprzez przekazywanie wartości, które są dorobkiem kultury.

Człowiek tylko w kulturze może żyć życiem prawdziwie ludzkim. Dążymy do prawdy, gdyż chcemy stworzyć wspólnotę i właśnie interaktywność daje szansę uczestnictwa i realizowania wspólnoty. Wbrew pesymistycznej wizji, że człowiek podda się maszynie, dochodzimy do wniosku, że internet daje środowisko możliwości integrowania społeczeństw. Jest to narzędzie - ale nie gwarant. Jeśli rozpoznamy dobrze internet, to może być dla nas nadzieja.

S łow a k lu c zow e: internet, zrównoważony rozwój, młodzież, ekologia, edukacja

Natalia Maria Ruman

\section{Роль экологического образования и ИТ образования в содействии устойчивому развитию человека}

Анн н т а ция

Мы живем во времена, когда доминируют СМИ, которые оказывают влияние практически на все сферы нашей жизни. В настоящее время трудно представить школьное образование без использования современных технологий, таких как компьютеры или Интернет. В контексте экологического кризиса и ряда связанных с ним угроз, которые несет современная цивилизация, включая угрозу конформизма или материализма, необходимо представить серию действий, предпринимаемых в сфере образования, чтобы помочь детям и их родителям противостоять современным угрозам. Интернет сегодня становится хорошим инструментом для использования информации.

В статье изложены теоретические соображения по актуальным проблемам современной цивилизации и гуманитарного образования, а именно вопросам, связанным с экологией, ис- 
пользованием современных технологий и коммуникаций. Он фокусирует внимание читателя на важных ценностях в образовании для устойчивого развития.

Сегодняшняя молодежь остро нуждается в помощи, поэтому концепция модели образования для устойчивого развития является чрезвычайно своевременной, очень необходимой и желательной. Определяется как процесс терпеливого построения интерьера прихода путем передачи ценностей, являющихся культурными достижениями.

Человек в одной только культуре может жить по-настоящему человеческой жизнью. Мы стремимся к правде, потому что хотим создать сообщество, и именно интерактивность дает нам возможность участвовать и реализовывать сообщество. В пессимистической картине, когда человек подчинится машине, мы приходим к выводу, что Интернет дает окружающей среде возможность интеграции обществ. Это инструмент, но не гарантия, если мы хорошо понимаем Интернет, тогда у нас может быть надежда.

К л ю ч е в ы е с л о в а: Интернет, устойчивое развитие, молодежь, экология, образование

Natalia Maria Ruman

\title{
El papel de la educación ecológica y la educación TIC en la promoción del desarrollo sostenible del ser humano
}

\author{
Resumen
}

Vivimos en tiempos dominados por los medios de comunicación, que tienen un impacto en prácticamente todos los ámbitos de nuestras vidas. Hoy en día, es difícil imaginar la educación escolar sin el uso de tecnologías modernas como los ordenadores o Internet. En el contexto de la crisis ecológica y de una serie de amenazas asociadas con la civilización contemporánea, incluida la amenaza del conformismo o el materialismo, es necesario presentar una serie de acciones a desarrollar en educación para ayudar a los niños y sus familias a enfrentarse a las amenazas contemporáneas. Internet hoy en día se está convirtiendo en una buena herramienta para explotar toda la información que ofrece.

El artículo presenta consideraciones teóricas sobre los problemas importantes de la civilización moderna y la educación humana, a saber, cuestiones relacionadas con la ecología, el uso de las tecnologías modernas y la comunicación. Centra la atención del lector en valores importantes en la educación para el desarrollo sostenible.

La juventud de hoy necesita ayuda desesperadamente, de ahí que el concepto de un modelo educativo para el desarrollo sostenible sea extremadamente oportuno, muy necesario y deseable. Éste es definido como el proceso de construir pacientemente, custodiando la transmisión de valores los cuales son logros culturales de una sociedad.

Solo en la cultura las personas pueden vivir una vida verdaderamente humana. Nos esforzamos por la verdad, porque queremos crear una comunidad y es la interactividad la que nos da la oportunidad de participar e implementar la comunidad. En toda la imagen pesimista que las personas serán sustituidas por las máquinas, llegamos a la conclusión de que Internet ofrece al entorno la posibilidad de integrar sociedades. Es una herramienta, pero no una garantía; si conocemos bien Internet, entonces puede haber esperanza para nosotros.

Pa labras clave: internet, desarrollo sostenible, juventud, ecología, educación 



$$
\begin{gathered}
\text { III } \\
\text { Reports }
\end{gathered}
$$





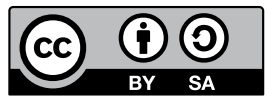

DOI 10.31261/IJREL.2018.4.2.08

\section{Eugenia Smyrnova-Trybulska}

Poland (ORCID: 0000-0003-1227-014X)

\section{A Report from the International Scientific Conference DLCC2018, 15-16 October 2018, Poland}

The $10^{\text {th }}$ edition of the International Scientific Conference DLCC2018: Theoretical and Practical Aspects of Distance Learning (www.dlcc.us.edu.pl) was held under the theme "E-learning and smart learning environment for preparing the specialists of new generation" and included reports from the IRNet project. The conference was held on 15-16 October 2018 in Wisła. It was organised by the Faculty of Ethnology and Educational Science at the University of Silesia in Cieszyn. The co-organisers were: the University of Ostrava (the Czech Republic); the Silesian University in Opava (the Czech Republic); the Constantine Philosopher University in Nitra (Slovakia); the Twente University (the Netherlands); the University of Extremadura (Spain); the Curtin University in Perth (Australia); the Borys Grinchenko Kiev University (Ukraine); the Herzen State Pedagogical University of Russia (Russia); the Dneprodzerzhinsk State Technical University (Ukraine); Ministry of Science and Higher Education, Poland; Polish Pedagogical Association, Branch in Cieszyn; Polish Scientific Association of Internet Education; IADIS - International Association for Development of the Information Society; and SEA - Polish Academic E-learning Association.

The conference tackled the following range of the topics:

1. E-environment and cyberspace e-environment of the university

- SMARTer education - preparing a new generation of e-learning specialists

- smart universities

- smart technology in education

- e-learning in a sustainable society

- Internet of things

2. Effective development of teachers' skills in the area of ICT and e-learning

- computer training for prospective and practicing teachers in the area of ICT and e-learning 
- teachers' and learners' competences in distance learning and computer science

- distance learning and lifelong learning

- self-learning based on Internet technology

3. E-learning and intercultural competences development in different countries

- legal, social, human, scientific, technical aspects of distance learning and e-learning in different countries

- psychological and ethical aspects of distance learning and e-learning in different countries

- collaborative learning in e-learning

4. E-learning methodology - implementation and evaluation

- European and national standards of e-learning quality evaluation

- evaluation of synchronous and asynchronous teaching and learning, methodology and good examples tion

- MOOCs - methodology of design, conducting, implementation, and evalua-

- contemporary trends in world education - globalisation, internationalisation, mobility

5. ICT tools - effective use in education

- selected Web 2.0 and Web 3.0 technologies

- LMS, CMS, VSCR, SSA, CSA

- cloud computing environment, social media

- multimedia resources and didactic materials, video-tutorial design

6. Theoretical, methodological aspects of distance learning

- successful examples of e-learning

- distance learning in humanities and science

- quality of teaching, training programmes and assessment

- e-learning for the disabled

7. E-learning in the development of key competences

- key competences in the knowledge society

- use of e-learning in improving the level of students' key competences

8. Alternative methods, forms, and techniques in distance learning

- simulations, models in distance learning

- networking

- distance learning systems

- m-learning

The conference was the essential event to summarise the results of the four years of the project entitled IRNet - "International research network for study and development of new tools and methods for advanced pedagogical science in the field of ICT instruments, e-learning and intercultural competences" (www.irnet.us.edu .pl). The project has been realised in the framework of $7^{\text {th }}$ Framework Programme, and financed by the European Commission and Polish Ministry of Science and Higher Education. Prof. Eugenia Smyrnova-Trybulska (Faculty of Ethnology and 
Educational Science) is a coordinator of the international consortium that includes ten institutions from nine countries. The idea of the project is based on the needs originating from the contemporary reality. It is the period of dynamic process in globalisation when theory and practice of e-learning as well as knowledge on multiculturality acquire the significant sense. It is apparent that the implementation of new and innovative tools in the educational activity is the necessary condition in the development of knowledge-based society. These goals will not be reached effectively unless these innovative forms and methods in education and distance education are implemented actively at all stages of education.

Over sixty scientific scholars from Poland and abroad participated in the conference, including members and professionals of the IRNet project, among others from the University of Extremadura (Spain); Linnaeus University, Kalmar (Sweden); the Comenius University in Bratislava (Slovakia); Plovdiv University "Paisii Hilendarski" (Bulgaria); the Lusíada University (Portugal); Kirchlische Pedagogische Hochschule, Vienna (Austria); Borys Grinchenko Kyiv University (Ukraine); the Gdańsk University of Technology (Poland); the Herzen State Pedagogical University of Russia, St. Petersburg (Russia); Peoples' Friendship University of Russia - RUDN University (Russia); the Jagiellonian University (Poland); the University of Warsaw (Poland); the Silesian University in Opava (the Czech Republic); Jesuit University of Philosophy and Education Ignatianum, Cracow (Poland); Slovak University of Agriculture in Nitra (Slovakia); University of Silesia in Katowice (Poland); University of Defence in Brno (the Czech Republic); Kostiantyn Ushynsky South Ukrainian National Pedagogical University (Ukraine); Rzeszów University of Technology (Poland); Maria CurieSkłodowska University in Lublin (Poland); Lublin University of Technology (Poland); Mykhailo Drahomanov National Pedagogical University, Kyiv (Ukraine); Kazimierz Wielki University in Bydgoszcz (Poland); Taras Shevchenko National University "Chernihiv Collegium" (Ukraine); University of Ostrava (the Czech Republic); Pedagogical University of Cracow (Poland); SWPS University of Social Sciences and Humanities, Warsaw (Poland); Dniprovsk State Technical University (Ukraine); Poznań University of Medical Sciences (Poland); Warsaw University of Technology (Poland); Higher School of Education of the Polytechnic Institute of Santarem (Portugal); Adam Mickiewicz University, Poznań (Poland); Ternopil University (Ukraine); Federal Research Centre "Computer Science and Control" of the Russian Academy of Sciences (Russia); State Higher Vocational School in Krosno (Poland); and many others.

The guests and conference members were welcomed by the Dean of Faculty of Ethnology and Educational Science prof. dr hab. Zenon Gajdzica on the first day of the conference.

The first day of the conference included two sessions: the plenary and thematic ones. 
During the plenary session (Plenary Session 1, chair: Eugenia SmyrnovaTrybulska), the first lecture was presented by prof. Maria Potes Barbas (Portugal): "Training in Digital Literacy the Labour Market: E-learning for Young People with Disabilities." She is a full professor at ESE-IPS - Polytechnic Institute of Santarém, and an invited associate professor at the Universidade Aberta (UAb), the Open University in Lisbon, Portugal. Prof. Maria Potes Barbas is a member of the Didactics and Technology in Education of Trainers Research Centre and a collaborative member of the Information and Society Department at FCT. The lecture demonstrated a good practice experience on how distance learning can be a beneficial learning aspect for young people with disabilities through the implementation of an innovative training course in digital literacy for the labour market.

The second lecture, entitled "Developing Smart-education in Conditions of Digitization," was presented by prof. Nataliia Morze (Ukraine), Vice Rector on IT at the Borys Grinchenko Kyiv University, and Chief of Department of Computer Science. Prof. Morze is also a State expert of National ICT Programme in Education, Elaboration of the National System of In-Service Teacher Training and School Heads Training according to ICT, Elaboration of the Teachers Technological Standards on National Level, Senior Trainer of Word Intel programme Teach to the future, Trainer of Microsoft programme Cooperation learning. Among her achievements are: elaboration of distance learning courses for teachers and students, elaboration of State programme of computer science for professionals, high schools and universities, elaboration of conception of implementation of computer science in education of Ukraine. Professor Morze is a teachers' trainer of computer science and author of more than 300 publications, articles, and monographs (70 books on e-learning, critical thinking, interactive methods, IT-teaching).

The third lecture, entitled "Get Smart Teachers through Digital Skills," was presented by prof. Antonio dos Reis (Portugal), Xabier Basogain (Spain), Olga Yakovleva (Russia), Prof. Reis is the Graal Institute Director and scientific coordinator, teacher and consulting adviser in e-learning multimedia projects; coordinator of the research project "Teacher's skills for the school of the future"; consulting advisor of the University for implementation of virtual classrooms; consulting advisor of WeZupport, Sweden, and for e-Campus global project; coordinator of postgraduate course "Pedagogic and didactic skills in e-learning and multimedia" (2008/09); teacher at Azores University (2007/08); Teacher trainer of teacher trainers in Portuguese Education Ministry; distance learning platform, Webmaster and multimedia coordinator in 2006 ISEG UTL (Technical University Lisbon); scientific ccoordinator of the pilot project "The school of the future today"; key speaker and conference chair at Azores - Online Learning Conference and Workshop 2008/2009; education website coordinator at: www.thegraal.net; author of more than 500 videos of conferences and pedagogic contents, e-round tables and debates, YouTube channel: www.youtube.com/user/antonodreis; Moodle 
platform administrator: http://thegraal.ccems.pt/. Olga V. Yakovleva, PhD, is an associate professor at the Herzen State Pedagogical University of Russia, St. Petersburg, employed at the Faculty of Information Technology. She is a teacher of the master's programme Information Technologies in Education; a developer of the content and teaching methods of disciplines: communication of virtual learning environment, educational activities in e-learning; a conductor of teacher training courses for teachers in the use of information technology in education, and the teacher of the Intel - Teach to the Future. Xabier Basogain is a professor of the University of the Basque Country - Euskal Herriko Unibertsitatea. He is an engineer of telecommunication at the Polytechnic University of Madrid and a doctor engineer of telecommunication by the University of the Basque Country. $\mathrm{He}$ is a member of the Department of Engineering Systems and Automatics of the School of Engineering of Bilbao, Spain. He has taught courses in digital systems, microprocessors, digital control, modelling and simulation of discrete events, machine learning, and collaborative tools in education. His research activities include the areas of: a) soft computing and cognitive sciences to STEM, b) learning and teaching technologies applied to online education and inclusive education, and c) augmented and virtual reality with mobile technologies. His research group (http://ehu.es/gmm) is integrated into the consolidated research groups of the Basque university system (2010). He has an extensive number of publications in scientific, academic, and social forums. He is editor-in-chief and member of committees of scientific journals / congresses, and he collaborates in European projects and participates in the development of social and educational projects with institutions of Latin American countries.

The fourth lecture, entitled "Technology at Work: Remote Supervision of Teaching Practice at a Swedish University," was given by Professor David Richardson (Sweden) from Linnaeus University, Kalmar Universite, Sweden. He presented experiences with remote supervision of teaching practice students from Linnaeus University in Sweden.

During the thematic session (Session 2, 11:20-13:15, chairs: Magdalena Roszak and Iwona Mokwa-Tarnowska), seven lectures were presented:

- Mariusz Marczak, Jarosław Krajka (Poland): "Call Training in Resourcelimited Circumstances: Student Teachers' Perspectives";

- Paloma Paniagua Martín, Sixto Cubo Delgado (Spain): "Big Data in Education. Attitudes of Teachers towards the Application of Big Data Techniques";

- Nuno Sotero Alves da Silva, Isabel Borges Alvarez, Paulo Pinto (Portugal): "A Case Study of Ethical Issues Affecting the Implementation of E-learning in a Cross-continental - Euro-African University";

- Nataliia Morze, Olena Kuzminska (Ukraine): "Students' Digital Portfolio as a Tool for Defining Generic Competences";

- Todorka Glushkova, Stanimir Stoyanov, Asya Stoyanova-Doycheva (Bulgaria): "Internet Of Things. Ecosystem Supporting E-learning"; 
- Magdalena Roszak, Iwona Mokwa-Tarnowska, Barbara Kołodziejczak (Poland): "SMARTer Education - Preparing a New Generation of University and College Teachers";

- Iwona Mokwa-Tarnowska, Barbara Kołodziejczak, Magdalena Roszak (Poland): "Online Collaborative Projects to Enhance Soft Skills."

In the framework of the conference, social and cultural events traditionally took place. For example, during $10^{\text {th }}$ edition the following events took place: the excursion (a tour to the castle in Wisła Residence of the President of the Republic of Poland at the springs of the Vistula river, and a walk along the crown of the Lake Czerniańskie dam at the junction of the Biała Wisełka and Czarna Wisełka rivers) and conference dinner in the Stok hotel restaurant.

On the second day of the conference, during plenary session, there were seven lectures. The first one, "The Use of Virtual Learning Environments in Improving Language and Communication Skills," was given by prof. dr hab. Halina Widła from the University of Silesia in Katowice (Poland).

Prof. Nataliia Morze - on behalf of the team of authors: Nataliia Morze, Oleksandr Burov, Svitlana Spivak (Ukraine) - presented the lecture entitled "Methodology of Research into the Dynamics Formation of Professionally Important Cognitive and Personal Qualities of IT-specialties Students."

Prof. Anna Ślósarz from the Pedagogical University in Cracow (Poland) presented the report on "The Smart Learning with a Talented and Poor Student."

A team of authors from Poland, Barbara Kołodziejczak, Iwona Mokwa-Tarnowska, and Magdalena Roszak - experts in area e-learning, members of the Polish Society of E-learning - presented the lecture entitled "Directions of the Evolution of Higher Education."

Slovakian researchers from Jan Comenius University in Bratislava, Jan Guncaga, Edita Partova, and Katarina Zilkova (Slovakia) presented the paper "Design of Educational Applets to Increase Children's Abilities to Recognize Patterns."

Spanish experts from the University of Extremadura, Peart Mark, Prudencia Gutiérrez-Esteban, and Sixto Cubo-Delgado conducted the lecture "Secondary Education Students' Technology Use in Digital Environments."

The last lecture, "Smarter University in a Smart Society - Some Trends," was prepared by Eugenia Smyrnova-Trybulska from the University of Silesia in Katowice (Poland)

During three thematic sessions more than forty lectures were presented by scientists and researchers from Spain, Slovakia, the Czech Republic, Poland, Ukraine, Russia, Austria, and other countries.

One of the most important events during the conference was the round table debate in presence and in remote mode (moderators: Eugenia Smyrnova-Trybulska and Magdalena Roszak) with the participation of the well-known experts and researchers from different countries (Figures 1,2): 


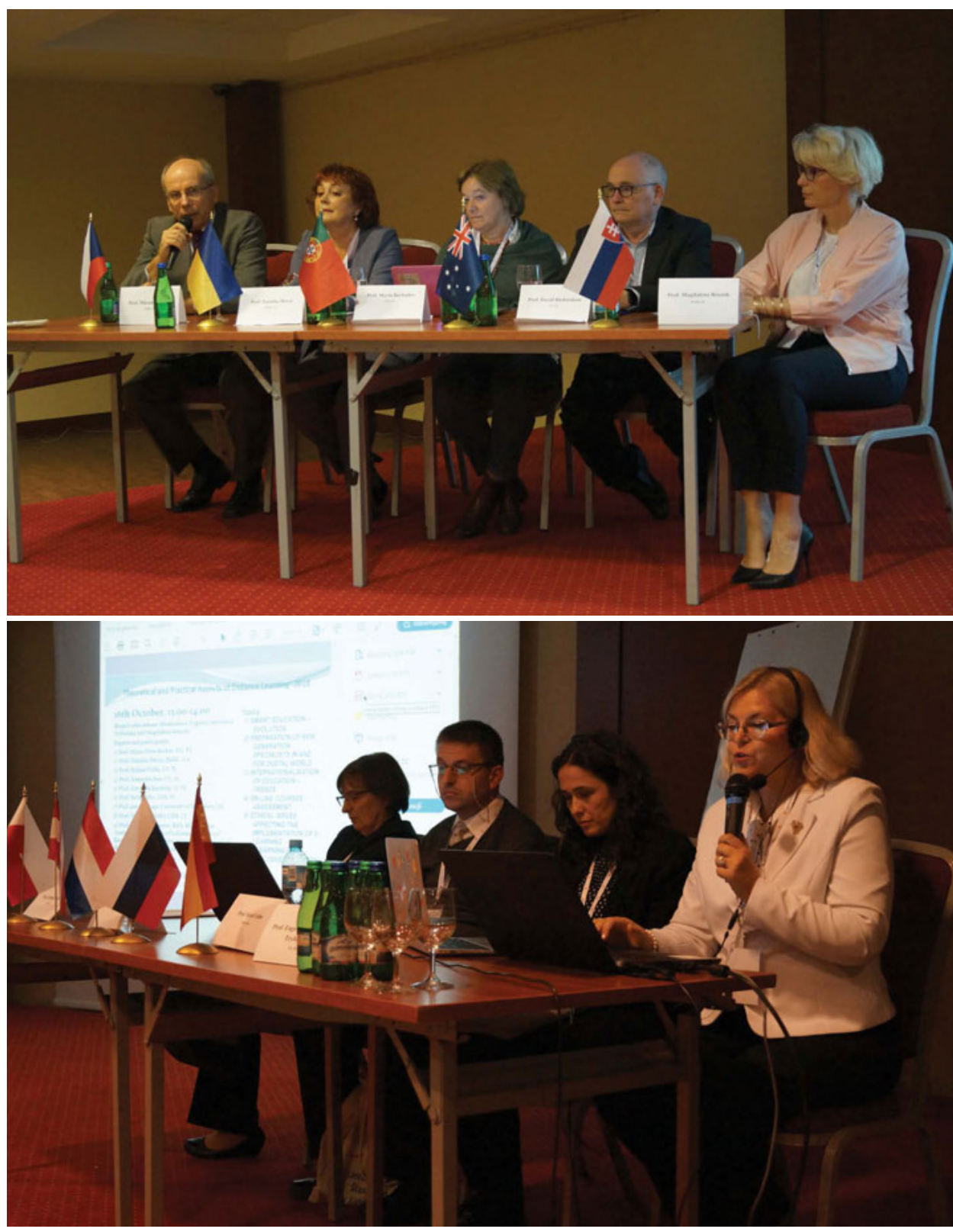

Figure 1, 2. Participants of the round table debate led by Eugenia SmyrnovaTrybulska from the University of Silesia in Katowice and Magdalena Roszak from the Poznań University of Medical Sciences (Poland), with the following professionals and experts from different countries: Prudencia Esteban (Spain), David Richardson (Sweden), Nataliia Morze (Ukraine), Halina Widła (Poland), Jan Guncaga (Slovakia), Mirosłav Hrubý (the Czech Rebublic), in remote mode Tomayess Issa (Australia), Olga Yakovleva (Russia). Photos by Andrzej Szczurek. 
1. Prof. Maria Potes Barbas, STI, PT;

2. Prof. Nataliia Morze, BGKU, UA;

3. Prof. Halina Widła, UŚ, PL;

4. Prof. Tomayess Issa, $\mathrm{CU}, \mathrm{AU}$;

5. Prof. David Richardson, LU, SE;

6. Prof. Sixto Cubo, UEX, ES;

7. Prof. Jan Guncaga, University of Bratislava, SK;

8. Prof. Miroslav Hrubý, UDB, CZ;

9. Prof. Diana Bogdanova, RAN, RU - on-line (Institute of Informatics Problems, the Federal Research Centre "Computer Science and Control" of the Russian Academy of Sciences);

10. Prof. Todorka Glushkova, Plovdiv University "Paisii Hilendarski," BG;

11. Prof. Antonio dos Reis, GI, PT - on-line;

12. Prof. Olga Yakovleva, HSPU, RU - on-line;

13. Prof. Xabier Basogain, BTU, ES - on-line.

Topics for discussion were the following:

- smart education - evolution,

- preparation of new generation specialists in and for digital world,

- internationalisation of education - trends,

- on-line courses assessment,

- ethical issues affecting the implementation of e-learning,

- e-learning in inclusive education.

A part of the conference programme and an important element of the conference was the workshop "Augmented Reality AR and Artificial Intelligence in Subject Lessons," conducted by Dawid Staniek (Poland), PhD student of the University of Silesia in Katowice. The guests and conference attendants actively participated in discussion and interactive activities (Figures 3, 4, 5).

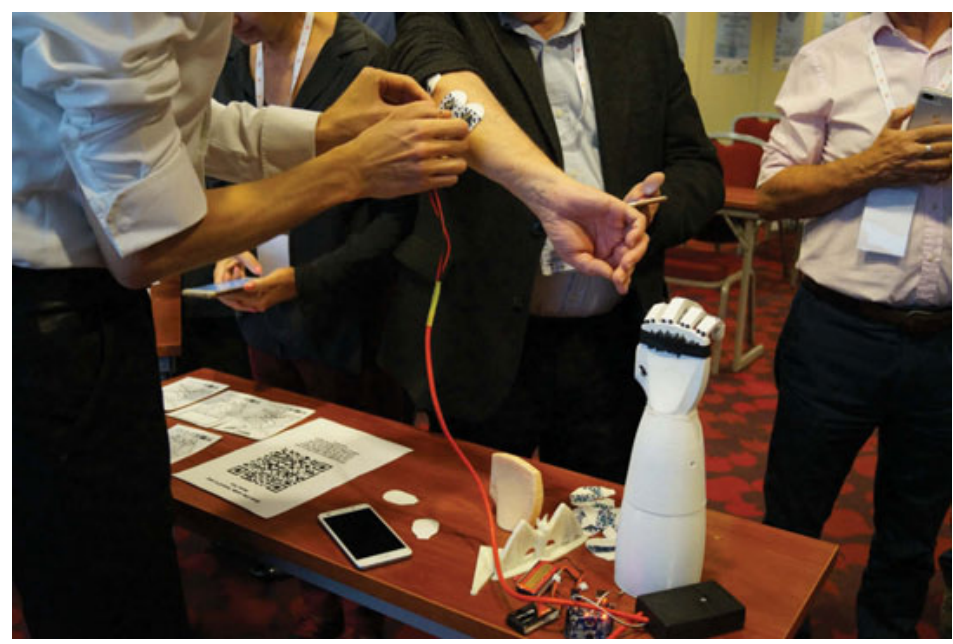



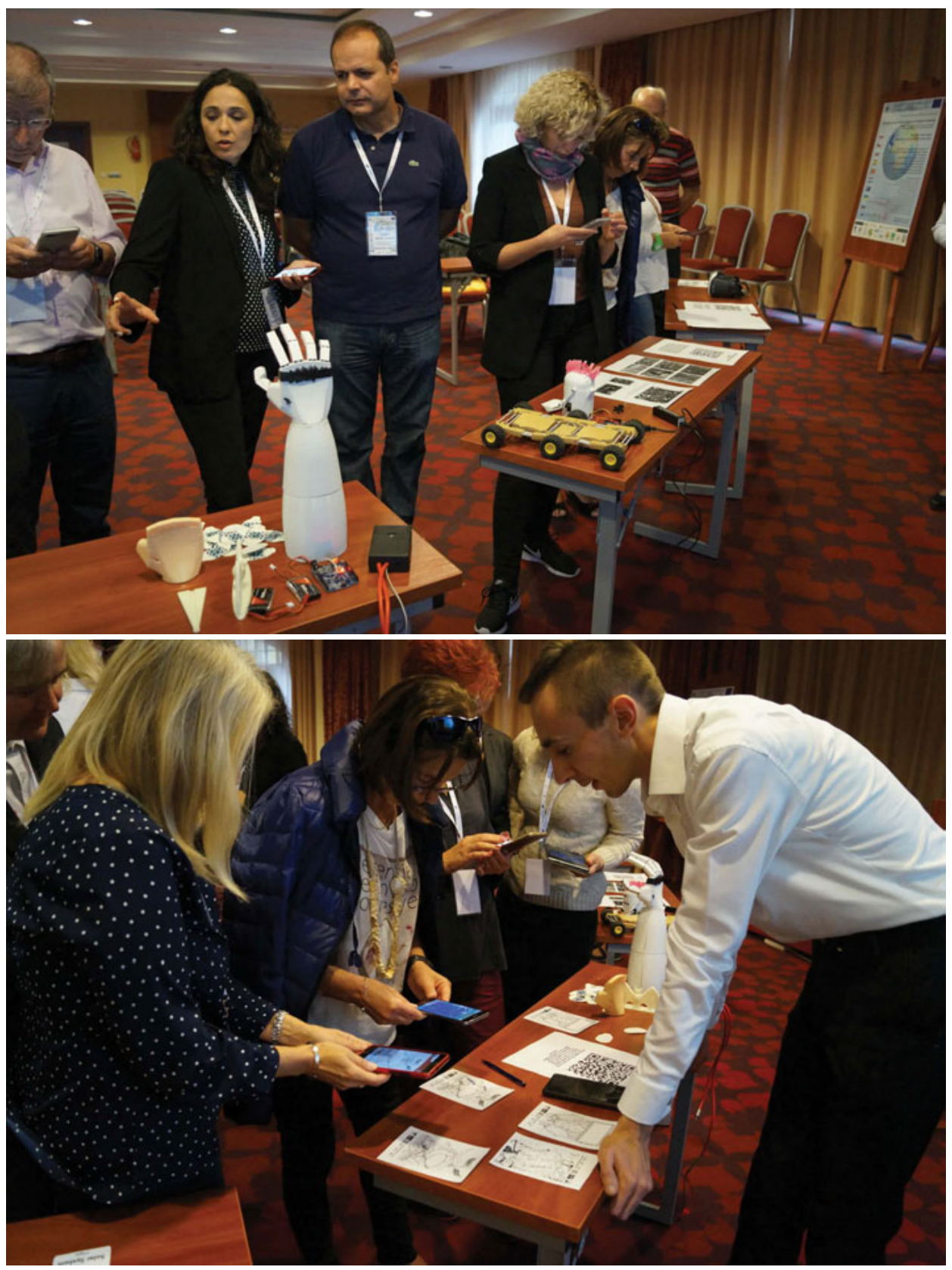

Figures 3, 4, 5. The workshop "Augmented Reality AR and Artificial Intelligence in Subject Lessons," conducted by Dawid Staniek. Photos by Andrzej Szczurek.

The participants of the International Scientific Conference DLCC2018 contribute significantly to the research area concerning new technologies in 
education and incorporation of current technological trends in teaching-learning methodologies. It is worth noting that the conference favours exchanging experiences, strengthening international cooperation, solving problems together, implementing innovative methodologies, and creating a global educational space. During the conference, numerous themes were discussed, including: further directions in international cooperation, new shared scientific and didactic projects, internationalisation development in the conditions of digitalisation and globalisation.

More information concerning conference can be found on the website www .dlcc.us.edu.pl.
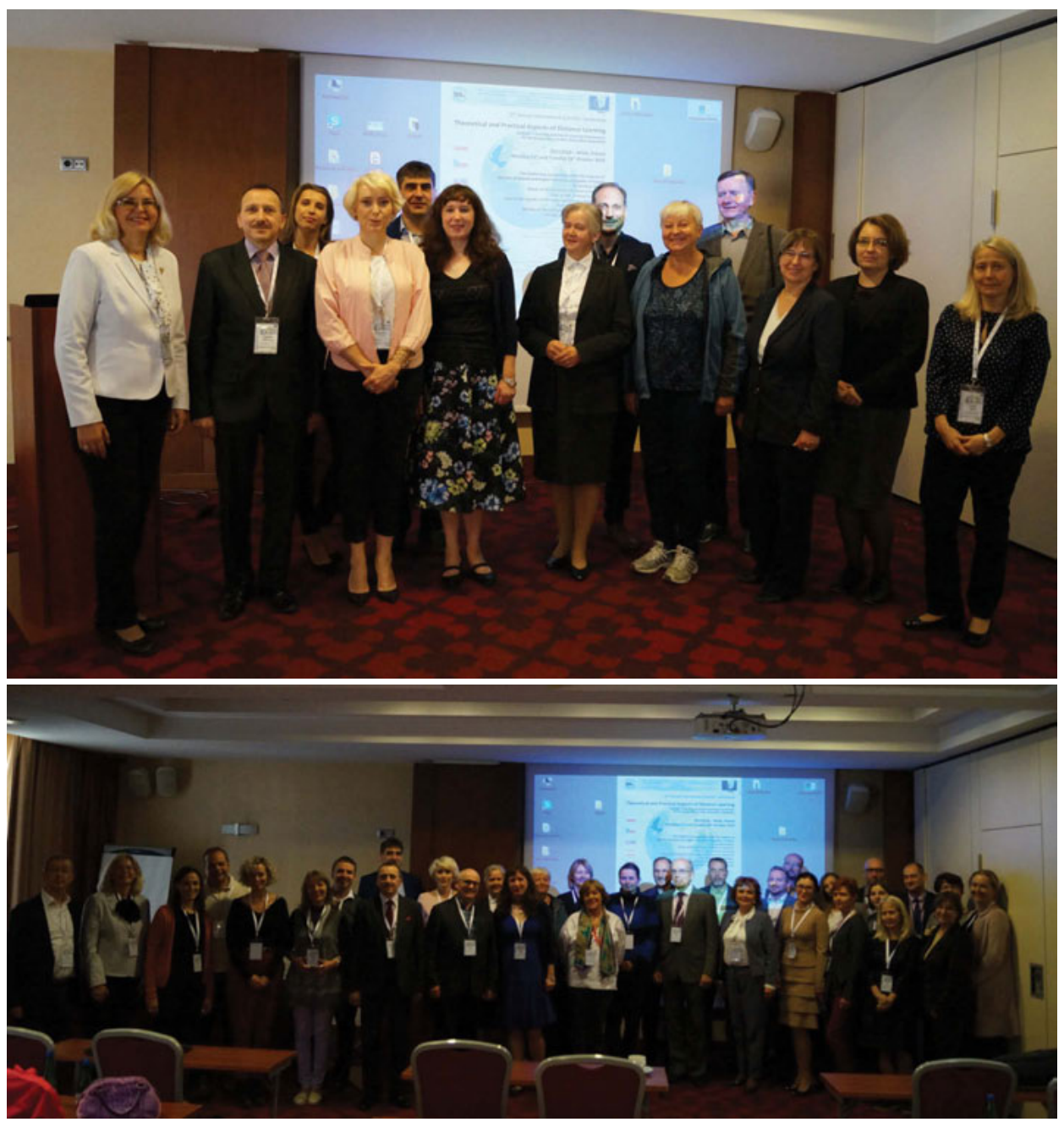

Figures 6, 7. Participants of the DLCC2018 conference and the EU IRNet project. Photos by Andrzej Szczurek. 


\section{Contributors}

Ahmed Masroor, Instructor at Department of Mass Communication, Virtual University of Pakistan (masroor.ahmed@vu.edu.pk).

Balyk Nadiia, PhD, hab., Department of Computer Science, Volodymyr Hnatiuk Ternopil National Pedagogical University, Ukraine (nadbal@ukr.net).

Din Aisha M, Lecturer at Department of Mass Communication, Virtual University of Pakistan (aishamdin@vu.edu.pk).

Haran Maryna, PhD, Kherson State University, Kherson, Ukraine (m.s.garan3009@gmail.com).

Hvorecký Jozef, PhD Laureate Programme, University of Liverpool, United Kingdom (jhvorecky@, vsm.sk).

Koreňová Lilla, PhD, Comenius University in Bratislava, Faculty of Education, Slovakia (korenova@, fedu.uniba.sk).

Morze Nataliia, PhD, hab., Full Professor, Corresponding Member of the National Academy of Educational Sciences of Ukraine, Doctor of Sciences in Pedagogy, professor, Borys Grinchenko Kyiv University, Vice-Rector on IT technology, Department of Computer Science, Ukraine (nmorze@kubg.edu.ua).

Ruman Natalia Maria, PhD, University of Silesia in Katowice, Faculty of Ethnology and Educational Science in Cieszyn, Poland (natalia.ruman@us.edu.pl).

Sadiq Saba, Lecturer at Department of Mass Communication, Virtual University of Pakistan (sabasadiq@vu.edu.pk).

Saleem Nadia, PhD, Department of Mass Communication, Virtual University of Pakistan, Pakistan (Nadia.Saleem@vu.edu.pk).

Skvortsova Svetlana, PhD, hab., Full Professor, South Ukrainian National Pedagogical University named after K. Ushynskyi, Odesa, Ukraine (skvo08@i.ua).

Smyrnova-Trybulska Eugenia, PhD, hab., associate professor, University of Silesia in Katowice, Faculty of Ethnology and Educational Science in Cieszyn, Poland (esmyrnova@us.edu.pl).

Shmyger Galina, PhD, hab., Department of Computer Science, Volodymyr Hnatiuk Ternopil National Pedagogical University, Ukraine (gal.sh27@gmail.com).

Strutynska Oksana, $\mathrm{PhD}$, associate professor, Vice-Dean of Scientific and International Activities, Faculty of Informatics, National Dragomanov Pedagogical University, Kyiv, ORCID ID 00000003-3555-070X (o.v.strutynska@npu.edu.ua).

Umryk Mariia, PhD, associate professor, Faculty of Informatics, Dragomanov National Pedagogical University, Kyiv, ORCID ID 0000-0002-0396-0045 (m.a.umryk@npu.edu.ua).

Vasylenko Yaroslav, PhD, Department of Computer Science, Volodymyr Hnatiuk Ternopil National Pedagogical University, Ukraine (yava07@gmail.com). 



\section{IJREL Reviewers}

Xabier Basogain, $\mathrm{PhD}$, ing. in telecommunications engineering at University of the Basque Country, Spain. Specialist and expert in the areas of science research, computer science, web 2.0, English educational technology, qualitative research, curriculum, design, programming, human computer interaction. Professor of the University of the Basque Country - Euskal Herriko Unibertsitatea. Engineer of telecommunication by the Polytechnic University of Madrid and doctor engineer of telecommunication by the University of the Basque Country. Member of the Department of Engineering Systems and Automatics of the School of Engineering of Bilbao, Spain. Has taught courses in digital systems, microprocessors, digital control, modelling and simulation of discrete events, machine learning, and collaborative tools in education. His research activities include the areas of: a) soft computing and cognitive sciences to STEM; b) learning and teaching technologies applied to online education and inclusive education; c) augmented and virtual reality with mobile technologies. His research group (http://ehu.es/gmm) is integrated into the consolidated research groups of the Basque university system (2010). Author of an extensive number of publications in scientific, academic, and social forums. Editor-in-chief and member of committees of scientific journals/congresses. Collaborates in European projects and participates in the development of social and educational projects with institutions of Latin American countries.

Nataliia Morze, Corresponding Member of the National Academy of Educational Sciences of Ukraine, Doctor of Sciences in Pedagogy, professor, Borys Grinchenko Kyiv University, ViceRector on IT technology, Department of Computer Science, Ukraine. State expert of National ICT Programme in Education, Elaboration of the National System of In-Service Teacher Training and School Heads Training according to ICT, Elaboration of the Teachers Technological Standards on National Level, Senior Trainer of Word Intel programme Teach to the future. Trainer of Microsoft programme Cooperation learning. Elaboration of distance learning courses for teachers and students. Elaboration of State programme of computer science for professionals, high schools, and universities. Elaboration of implementation of computer science in education of Ukraine. Teachers' trainer of computer science. Author of more than 300 publications, articles, and monographs (70 books on e-learning, critical thinking, interactive methods, IT-teaching).

Henryk Krzysteczko, prof., dr hab., head and lecturer at the consulting point of the postgraduate studies in family studies at the Institute of Family Studies at the Academy of Catholic Theology in Warsaw - Consultation Point in Katowice (1985-1999), manager of the postgraduate studies in family and judicial mediation, lecturer in theology and pastoral psychology at the GustavSiewerth-Akademie in Weilheim-Bierbronnen (2004-2008). Since 2004 - manager of the section of psychology at the Commission for the Faith of the Conference of the Polish Episcopate. Since 1995 - vice-chairman of the Family Council at the Sejmik of the Silesian Voivodeship and 
the Governor of Katowice. Manager of the Diocesan and later the Archdiocesan Family Life Counselling. Consultant of the Commission for Vocations and Formation to the Presbyterate of the Second Synod of the Archdiocese of Katowice. Author of the books: Pastoral counselling (1998); Psychological correlates of penitent attitudes towards confession (1998); Helping to mature for love, marriage and family (2000); Volunteering in non-governmental organisations for the benefit of the family in the Silesia Voivodship (2001); In a small religious group (2003).

Iryna Sekret, $\mathrm{PhD}$, hab., professor (Abbant Izzet Baysal University, Turkey). In 1996 graduated from Dnipropetrovsk State University as a specialist in practical psychology and teaching English. In 2002 defended a PhD dissertation on educational psychology in Kyiv. During that period was teaching in Verkhnyodniprovsk Agricultural College, Dnipropetrovsk State University and Dniprodzerzhinsk State Technical University. Since 2004 - head of the Foreign Languages Department and Vice-Dean of the Philology and Sociology Faculty (2007, 2010-2011) in Dniprodzerzhinsk State Technical University. The defence of the dissertation for the degree of the Doctor of Pedagogical Sciences was held in 2012 in Kyiv. Her scientific interests include e-learning, methods of teaching, linguistics, educational psychology.

Renata Stefańska-Klar, PhD, University of Silesia in Katowice, Faculty of Ethnology and Educational Science in Cieszyn, Poland. Currently works at the Faculty of Ethnology and Educational Science, University of Silesia in Katowice. Does research in qualitative social research, quantitative social research, and educational psychology. Current projects include "Psychological well-being of children and adolescents in context of school functioning and mental health prevention" and "Sex/gender differences in autism spectrum condition (ASC) and their consequences." Member of the Polish Psychological Association, American Psychological Association, American Association on Intellectual and Developmental Disabilities, International Society on Early Intervention, Council of Exceptional Children/Division of Autism and Developmental Disorders, Autism-Europe, Puente Del Arte Association. Skills and expertise and scientific interests: pedagogy and education, learning, counselling, mental illness, psychological assessment, e-learning.

Anna Studenska, PhD, hab., University of Silesia in Katowice, Faculty of Ethnology and Educational Science in Cieszyn, Poland. In 2004 obtained a PhD in pedagogy. Since 1998 has been working at University of Silesia in Katowice. Currently employed at the Faculty of Ethnology and Educational Science. Has been conducting courses of informational technology in foreign language learning, information technology in pre-school and primary education, biomedical bases of development and education, research methods in pedagogy and pedagogical diagnostics. Her main scientific interests include learning autonomy and its support by teachers. Author of the book on foreign language learning strategies, manual for the instrument to measure perceived difficulty in autonomous learning and articles concerning relationship between individual traits, environmental variables, and learning autonomy.

Jolanta Szulc, PhD, inż., University of Silesia in Katowice, Poland, Faculty of Philology, Institute of Library and Information Science. Doctor of humanities, specialty: bibliology, engineer. Graduated from the University of Silesia in Katowice, Faculty of Philology (1991), Faculty of Theology at the John Paul II Catholic University of Lublin (1997), the Jagiellonian University Department of Management and Social Communication (2001), the Faculty of Mechanical Engineering (2008) and the Faculty of Automatic Control, Electronics And Computer Science (2012) at the Silesian University of Technology. Assistant professor (adiunkt) at the Institute of Library and Information Science at the University of Silesia in Katowice since 2006. Specialises 
in descriptive cataloguing, subject cataloguing and indexing, information systems, information languages, expert systems, and e-learning. Author of several articles in books and journals. Member of the Polish Society of Scientific Information and the ISKO: International Society for Knowledge Organisation, member of Association of Academic E-learning, honorary member of the Federation of the Polish Church Libraries FIDES.

Olga Yakovleva, $\mathrm{PhD}$, associate professor, Faculty of Information Technology, Herzen State Pedagogical University in Saint Petersburg, Russia. Teacher of the master's programme in information technologies in education. Developer of the content and teaching methods of disciplines: communication of virtual learning environment and educational activities in e-learning. Teacher training courses of teachers in the use of information technology in education. Teacher of the Intel - Teach to the Future. 



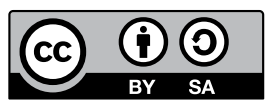

\title{
In the "E-learning" series
}

http://weinoe.us.edu.pl/nauka/serie-wydawnicze/seria-e-learning/seria-e-learning

\author{
ISSN 2451-3644 \\ (print edition) \\ ISSN 2451-3652 \\ (digital edition)
}

1. Theoretical and practical aspects of distance learning. Ed. E. Smyrnova-Trybulska. Cieszyn: Wydawnictwo Uniwersytetu Śląskiego, 2009, 308p. ISBN 978-83-925281-4-2.

2. Use of e-learning in the training of professionals in the knowledge society. Monograph. Ed. E. Smyrnova-Trybulska. Cieszyn: Wydawnictwo Uniwersytetu Śląskiego, Studio Noa, 2010, 344p. ISBN 978-83-60071-30-4.

3. Use of e-learning in the developing of the key competences. Monograph. Ed. E. SmyrnovaTrybulska. Katowice-Cieszyn: Wydawnictwo Uniwersytetu Śląskiego, Studio Noa, 2011, 462p. ISBN 978-83-60071-39-7.

4. E-learning for societal needs. Monograph. Ed. E. Smyrnova-Trybulska. Katowice: Wydawnictwo Uniwersytetu Śląskiego, Studio Noa, 2012, 557p. ISBN 978-83-60071-59-5.

5. E-learning and lifelong learning. Monograph. Ed. E. Smyrnova-Trybulska. Katowice-Cieszyn: Wydawnictwo Uniwersytetu Śląskiego, Studio Noa, 2013, 587p. ISBN 978-83-60071-66-3.

6. E-learning and intercultural competences development in different countries. Monograph. Ed. E. Smyrnova-Trybulska. Katowice-Cieszyn: Wydawnictwo Uniwersytetu Śląskiego, Studio Noa, 2014, 484p. ISBN 978-83-60071-76-2.

7. IT tools - Good practice of effective use in education. Monograph. Ed. E. Smyrnova-Trybulska. Katowice-Cieszyn: Wydawnictwo Uniwersytetu Śląskiego, Studio Noa, 2015, 408p. ISBN 978 83-60071-82-3.

8. E-learning methodology - Implementation and evaluation. Monograph. Ed. E. SmyrnovaTrybulska. Katowice-Cieszyn: Wydawnictwo Uniwersytetu Śląskiego, Studio Noa, 2016. ISSN 2451-3644 (print edition) ISSN 2451-3652 (digital edition) ISBN 978-83-60071-86-1.

9. Effective development of teachers' skills in the area of ICT and e-learning. Monograph. Ed. E. Smyrnova-Trybulska. Katowice-Cieszyn: Wydawnictwo Uniwersytetu Śląskiego, Studio Noa, 2017. ISSN 2451-3644 (print edition) ISSN 2451-3652 (digital edition) ISBN 978-83-60071-96-0.

10. E-learning and smart learning environment for the preparation of new generation specialists. Monograph. Ed. E. Smyrnova-Trybulska. Katowice-Cieszyn: Wydawnictwo Uniwersytetu Śląskiego, Studio Noa, 2018. ISSN 2451-3644 (print edition) ISSN 2451-3652 (digital edition) ISBN 978-83-66055-05-6.

\section{Monograph}

1. Smyrnova-Trybulska, E.: Technologie informacyjno-komunikacyjne i e-learning we współczesnej edukacji. Katowice: Wydawnictwo Uniwersytetu Śląskiego, 2018. ISBN 978-83-226-3070-9. 


\section{Coursebooks on e-learning}

1. Wykorzystanie LCMS Moodle jako systemu wspomagania nauczania na odległość. Podręcznik akademicki. Ed. E. Smyrnova-Trybulska, S. Stach. Authors: E. Smyrnova-Trybulska, A. Burnus, A. Szczurek. Katowice: Wydawnictwo Uniwersytetu Śląskiego, Studio Noa, 2012, 560p. ISBN 978-83-60071-56-4 (http://www.wydawnictwo.us.edu.pl/node/3721).

2. Zastosowanie systemów CMS w tworzeniu przestrzeni informacyjno-edukacyjnej w Internecie. Podręcznik akademicki. Ed. E. Smyrnova-Trybulska, S. Stach. Authors: E. Smyrnova-Trybulska, S. Stach, B. Fuklin, D. Staniek. Katowice: Wydawnictwo Uniwersytetu Śląskiego, Studio Noa, 2012, 194p. ISBN 978-83-60071-55-7 (http://www.wydawnictwo.us.edu.pl/node/3731). 



\section{Contact}

International Journal of Research in E-learning

University of Silesia

Faculty of Ethnology and Sciences of Education

Bielska 62, 43-400 Cieszyn, Poland

phone: +48338546113

fax: +48338546101

email: esmyrnova@us.edu.pl

Copy editing and proofreading

Anna Kisiel

Cover design

Emilia Dajnowicz

Typesetting

Hanna Olsza

Creative Commons Attribution-ShareAlike 4.0 International

Electronic version is the original one.

The journal was previously published in printed form with the ISSN 2451-2583

The journal is distributed free of charge ISSN 2543-6155

Published by

Wydawnictwo Uniwersytetu Śląskiego

ul. Bankowa 12B, 40-007 Katowice

www.wydawnictwo.us.edu.pl

e-mail: wydawus@us.edu.pl

Printed sheets: 8.4 .

Publishing sheets: 8.4 . 


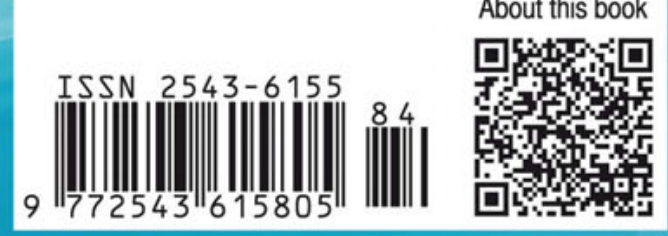

